\title{
Review \\ Fluid Processes of Wolframite-Quartz Vein Systems: Progresses and Challenges
}

\author{
Pei Ni * (1), Wen-Sheng Li, Jun-Yi Pan, Jian-Ming Cui, Kai-Han Zhang and Yan Gao
}

Citation: Ni, P.; Li, W.-S.; Pan, J.-Y.; Cui, J.-M.; Zhang, K.-H.; Gao, Y. Fluid Processes of Wolframite-Quartz Vein Systems: Progresses and Challenges. Minerals 2022, 12, 237. https:// doi.org/10.3390/min12020237

Academic Editor: Pierre Schiano

Received: 26 November 2021

Accepted: 4 February 2022

Published: 12 February 2022

Publisher's Note: MDPI stays neutral with regard to jurisdictional claims in published maps and institutional affiliations.

Copyright: () 2022 by the authors Licensee MDPI, Basel, Switzerland. This article is an open access article distributed under the terms and conditions of the Creative Commons Attribution (CC BY) license (https:// creativecommons.org/licenses/by/ $4.0 /)$.

\author{
State Key Laboratory for Mineral Deposits Research, Institute of Geo-Fluids, School of Earth Sciences and \\ Engineering, Frontiers Science Center for Critical Earth Material Cycling, Nanjing University, \\ Nanjing 210093, China; lws3611@163.com (W.-S.L.); pjynju2010@126.com (J.-Y.P.); \\ jmcui1996@hotmail.com (J.-M.C.); zhangkaihan7143@hotmail.com (K.-H.Z.); njugaoyan@126.com (Y.G.) \\ * Correspondence: peini@nju.edu.cn; Tel.: +86-25-89680883; Fax: +86-25-89682393
}

\begin{abstract}
Wolframite-quartz vein-type tungsten deposits constitute the world's major tungsten resources and are integral to tungsten production. A major share of this mineralization product is found in Southeast China, with other significant resources in the Central Andean belt, the East Australian belt, the Karagwe-Ankole belt and the European Variscan belt. In the past few decades, extensive studies on wolframite-quartz vein-type tungsten deposits have been conducted, but many key questions concerning their ore-forming fluid and metallogenic mechanism remain unclear. Additionally, a summary work on the global distribution and fluid characteristics of these wolframite-quartz vein-type tungsten deposits is still lacking. In this contribution, recent progress regarding several major issues related to the fluid processes involved in the forming of these veins are overviewed, and challenges in terms of future research are proposed. These issues include the nature of ore-forming fluids, their sources, and their transportation and wolframite deposition mechanisms. In particular, the affinity between veins and the exposed granitic intrusion from the Zhangtiantang-Xihuashan ore district, where an as-yet undiscovered deep intrusion, rather than the exposed granitic intrusion, was probably responsible for the formation of the wolframite-quartz veins, is reevaluated. This study also reviews the existing fluid and melt inclusion data from several tungsten deposits to address whether the mineralization potential of the magmatic-hydrothermal systems was directly correlated with the metal contents in the granitic melts and the exsolving fluids.
\end{abstract}

Keywords: wolframite-quartz vein; Nanling; magmatic-hydrothermal; fluid \& melt inclusion; metallogenic mechanism

\section{Introduction}

Wolframite-quartz vein-type tungsten deposits, generally related to granitic intrusions, are the source of much of the tungsten used by humans [1-8]. Mineralization of these deposits generally consists of wolframite (dominantly $\mathrm{FeWO}_{4}$ or $\mathrm{MnWO}_{4}$ ) in subhorizontal centimeter- to meter-scale quartz veins with lateral extents of hundreds of meters. The significant advantages of this type of tungsten deposit other than scheelite skarn are not only that it is easier for mining, but also due to the specialty of wolframite, which are more amenable to mineral processing [9]. In China, the exploitation of wolframite-quartz veins can be traced back to the Song Dynasty. However, the early mining activities were restricted to the utilization of quartz and cassiterite, which are common by-products of wolframite-quartz veins. Large-scale mining activities of wolframite-quartz veins began to break out around the beginning of last century. For example, wolframite in South China was first found in the Xihuashan tungsten deposit, and its mining and utilization officially took place in 1907. Panasqueira, which is located in Portugal, is the second largest tungsten mine in Europe and has been active for ca. 130 years with a total production of 76,000 metric tons of W since 1934 [8]. Because of its important economic significance, a significant number 
of studies on the fluid processes of wolframite-quartz vein-type $\mathrm{W}$ deposits have been carried out all over the world [4,5,10-21]. However, preliminary reviews on their global distribution, fluid processes and metallogenic mechanism are relatively scarce.

The formation of hydrothermal ore deposits, especially for magmatic-hydrothermal deposits, are generally related to hydrothermal fluids carrying metal elements. Therefore, the study of ore-forming fluid properties is very important to understand the material source and formation process of the deposits, and also to determine the deployment of geological exploration and prospecting work. The wolframite-quartz vein-type tungsten deposits belong to typical magmatic hydrothermal deposits, and magmatic hydrothermal activity is the dominant process controlling the supply, migration and precipitation of elements with economic value $[4,6,13,15,17,18,22,23]$. For a long time, the nature and source of magmatic hydrothermal fluid that led to the formation of these deposits has been discussed. In the early part of the last century, qualitative description of mineralization and hydrothermal alteration were the main methods to determine the features of oreforming fluid responsible for tungsten mineralization, due to the limitations of analytical technology [24-27]. Since the 1960s, fluid inclusion analysis was successfully applied to explore the features of ore-forming fluids [28-31]. As fluid inclusions were trapped within mineral growth during hydrothermal processes, they provided a unique means of directly characterizing the fluid responsible for mineralization. Although mineral geochemical and isotopic studies have also provided a broad knowledge on the fluid processes, the main focus of this paper is on fluid inclusion-related studies, which enables the direct compilation and comparison of global data. During the last half century, the fluid inclusion method was widely applied to constrain the fluid properties of wolframite-quartz veintype deposits, and a large number of microthermometric results of ore-forming fluids were reported $[4,6,11,13,15,22,32-37]$. Although a series of important discoveries has been achieved in relation to the hydrothermal processes forming these deposits, there are still different views on the sources of ore-forming materials, the properties of ore-forming fluids and the wolframite deposition mechanism, which hinder the establishment of the metallogenic model. For example, in terms of the properties of ore-forming fluids, there are two different viewpoints: the magma-hydrothermal transition state and aqueous solution fluid $[4,6,22,35,38,39]$. The selective appearance of $\mathrm{CO}_{2}$-rich fluids in different ore deposits brings confusion to the role of volatiles in mineralization $[4,6,17]$. In addition, the source of ore-forming materials is also debated between magma and wall rocks $[9,13]$. Moreover, simple cooling of ore-forming fluid, fluid mixing, fluid-rock interaction and fluid boiling were put forward to explain the mechanism controlling wolframite deposition, and there is still no unified conclusion $[4,6,9,13,15,17]$.

In this paper, we begin with a preliminary review and synthesis of the geological and distribution of wolframite-quartz vein-type tungsten deposits from all over the world, providing a view toward better understanding the metallogenic background of these tungsten deposits (Table 1). By combining the study of geological characteristics with research on ore-forming fluids, we attempt to provide tentative answers to some relevant questions, including the following: What are the general properties of fluids forming wolframite-quartz veins? What is the sequential relationship between wolframite and associated quartz? Does $\mathrm{CO}_{2}$ play an important role in the transport and precipitation of tungsten? Where are the ore-forming fluids sourced from? What are the main depositional controls for wolframite? In addition, the genetic link between veins and related granite is discussed for the Zhangtiantang-Xihuashan ore district based on their geological relationships and fluid properties to evaluate whether the exposed granitic intrusions were the direct parental rock for wolframite-quartz vein formation. Finally, this paper summarizes some recent single melt and fluid inclusion compositional data from W (-Sn) and other typical magmatichydrothermal systems, on the basis of which the compositions of ore-forming and ore barren melts/fluids are discussed comparatively. 
Table 1. Summary of the characteristics of wolframite quartz vein $\mathrm{W}$ deposits from all over the world, including chronological data and $\mathrm{WO}_{3}$ reserves.

\begin{tabular}{|c|c|c|c|c|c|c|c|c|c|c|}
\hline Name & Location & $\begin{array}{c}\text { Mineralization } \\
\text { Type }\end{array}$ & Resource & $\begin{array}{c}\text { W Reserve } \\
\left(10^{4} t\right)\end{array}$ & $\begin{array}{c}\text { Ore } \\
\text { Mineral }\end{array}$ & Wall-Rock & $\begin{array}{l}\text { Granitic } \\
\text { Intrusion }\end{array}$ & Age & Method & Reference \\
\hline Dajishan & $\begin{array}{c}\text { Quannan, } \\
\text { Jiangxi }\end{array}$ & $\begin{array}{c}\text { Wolframite- } \\
\text { quartz } \\
\text { vein }\end{array}$ & $\mathrm{W}$ & 16 & $\begin{array}{l}\text { Wolframite; } \\
\text { Scheelite }\end{array}$ & $\begin{array}{c}\text { Cambrian } \\
\text { metasedimen- } \\
\text { tary }\end{array}$ & $\begin{array}{c}\text { Fine-grained } \\
\text { muscovite } \\
\text { granite }\end{array}$ & $161 \pm 1.3$ & $\begin{array}{l}\text { Molybdenite } \\
\text { Re-Os }\end{array}$ & [40] \\
\hline Baxiannao & $\begin{array}{l}\text { Shangyou, } \\
\text { Jiangxi }\end{array}$ & $\begin{array}{l}\text { Wolframite- } \\
\text { quartz } \\
\text { vein }\end{array}$ & W & 2.9 & $\begin{array}{l}\text { Wolframite; } \\
\text { Scheelite }\end{array}$ & $\begin{array}{l}\text { Cambrian } \\
\text { metasedimen- } \\
\text { tary }\end{array}$ & $\begin{array}{c}\text { Fine-grained } \\
\text { porphyritic } \\
\text { granite }\end{array}$ & $157 \pm 1.5$ & $\begin{array}{l}\text { Molybdenite } \\
\text { Re-Os }\end{array}$ & [41] \\
\hline Anqiantan & Yudu, Jiangxi & $\begin{array}{c}\text { Wolframite- } \\
\text { quartz } \\
\text { vein }\end{array}$ & $\mathrm{W}-\mathrm{Bi}$ & & $\begin{array}{l}\text { Wolframite; } \\
\text { Scheelite }\end{array}$ & $\begin{array}{l}\text { Cambrian- } \\
\text { Devonian } \\
\text { metasedimen- } \\
\text { tary }\end{array}$ & $\begin{array}{c}\text { Fine-grained } \\
\text { porphyritic } \\
\text { granite }\end{array}$ & $156.1 \pm 3.6$ & $\begin{array}{l}\text { Molybdenite } \\
\text { Re-Os }\end{array}$ & [42] \\
\hline Kuimeishan & $\begin{array}{l}\text { Dingnan, } \\
\text { Jiangxi }\end{array}$ & $\begin{array}{l}\text { Wolframite- } \\
\text { quartz } \\
\text { vein }\end{array}$ & W-Bi & 5.3 & $\begin{array}{l}\text { Wolframite; } \\
\text { Scheelite }\end{array}$ & $\begin{array}{l}\text { Cambrian } \\
\text { metasedimen- } \\
\text { tary }\end{array}$ & Biotite granite & $153.7 \pm 1.5$ & $\begin{array}{l}\text { Molybdenite } \\
\text { Re-Os }\end{array}$ & [43] \\
\hline Jiulongnao & $\begin{array}{l}\text { Chongyi, } \\
\text { Jiangxi }\end{array}$ & $\begin{array}{l}\text { Wolframite- } \\
\text { quartz } \\
\text { vein }\end{array}$ & W-Sn & 1.9 & $\begin{array}{l}\text { Wolframite; } \\
\text { Cassiterite }\end{array}$ & $\begin{array}{c}\text { Fine-grained } \\
\text { biotite granite }\end{array}$ & $\begin{array}{c}\text { Fine-grained } \\
\text { biotite granite }\end{array}$ & $151.5 \pm 1.1$ & $\begin{array}{c}\text { Molybdenite } \\
\text { Re-Os }\end{array}$ & [44] \\
\hline Zhangdongkeng & $\begin{array}{l}\text { Chongyi, } \\
\text { Jiangxi }\end{array}$ & $\begin{array}{c}\text { Wolframite- } \\
\text { quartz } \\
\text { vein }\end{array}$ & W & & $\begin{array}{l}\text { Wolframite; } \\
\text { Cassiterite }\end{array}$ & $\begin{array}{l}\text { Cambrian } \\
\text { metasedimen- } \\
\text { tary }\end{array}$ & $\begin{array}{c}\text { Fine-grained } \\
\text { biotite granite }\end{array}$ & $151.3 \pm 1.7$ & $\begin{array}{l}\text { Molybdenite } \\
\text { Re-Os }\end{array}$ & {$[44]$} \\
\hline Maoping & $\begin{array}{l}\text { Chongyi, } \\
\text { Jiangxi }\end{array}$ & $\begin{array}{c}\text { Wolframite- } \\
\text { quartz } \\
\text { vein }\end{array}$ & W-Mo & 10.8 & $\begin{array}{l}\text { Wolframite; } \\
\text { Molybdenite }\end{array}$ & $\begin{array}{l}\text { Cambrian } \\
\text { metasedimen- } \\
\text { tary }\end{array}$ & $\begin{array}{c}\text { Fine-grained } \\
\text { biotite granite }\end{array}$ & $156.8 \pm 1.5$ & $\begin{array}{c}\text { Cassiterite } \\
\text { U-Pb }\end{array}$ & [45] \\
\hline Muziyuan & $\begin{array}{l}\text { Chongyi, } \\
\text { Jiangxi }\end{array}$ & $\begin{array}{l}\text { Wolframite- } \\
\text { quartz } \\
\text { vein }\end{array}$ & W-Sn & 0.6 & $\begin{array}{l}\text { Wolframite; } \\
\text { Cassiterite }\end{array}$ & $\begin{array}{l}\text { Cambrian } \\
\text { metasedimen- } \\
\text { tary }\end{array}$ & Biotite granite & $151 \pm 8.5$ & $\begin{array}{l}\text { Molybdenite } \\
\text { Re-Os }\end{array}$ & [46] \\
\hline Xushan & Jiangxi & $\begin{array}{l}\text { Wolframite- } \\
\text { quartz } \\
\text { vein }\end{array}$ & $\mathrm{W}$ & & Wolframite & Neoproterozoic & Granite & $147.1 \pm 3.4$ & $\mathrm{Rb}-\mathrm{Sr}$ & [47] \\
\hline Xingluokeng & Fujian & $\begin{array}{l}\text { Wolframite- } \\
\text { quartz } \\
\text { vein }\end{array}$ & $\mathrm{W}$ & & $\begin{array}{l}\text { Wolframite; } \\
\text { Scheelite }\end{array}$ & Granite & Granite & $156.3 \pm 4.8$ & $\begin{array}{l}\text { Molybdenite } \\
\text { Re-Os }\end{array}$ & [40] \\
\hline Niuling & $\begin{array}{l}\text { Chongyi, } \\
\text { Jiangxi }\end{array}$ & $\begin{array}{l}\text { Wolframite- } \\
\text { quartz } \\
\text { vein }\end{array}$ & W-Sn & 2.9 & $\begin{array}{l}\text { Wolframite; } \\
\text { Cassiterite }\end{array}$ & $\begin{array}{c}\text { Cambrian } \\
\text { metamor- } \\
\text { phosed } \\
\text { sandstone }\end{array}$ & $\begin{array}{l}\text { Calc-alkaline } \\
\text { granite }\end{array}$ & $152 \pm 8.5$ & $\begin{array}{l}\text { Molybdenite } \\
\text { Re-Os }\end{array}$ & [44] \\
\hline
\end{tabular}


Table 1. Cont.

\begin{tabular}{|c|c|c|c|c|c|c|c|c|c|c|}
\hline Name & Location & $\begin{array}{c}\text { Mineralization } \\
\text { Type }\end{array}$ & Resource & $\begin{array}{c}\text { W Reserve } \\
\left(10^{4} t\right)\end{array}$ & $\begin{array}{c}\text { Ore } \\
\text { Mineral }\end{array}$ & Wall-Rock & $\begin{array}{l}\text { Granitic } \\
\text { Intrusion }\end{array}$ & Age & Method & Reference \\
\hline Panguahsn & Yudu, Jiangxi & $\begin{array}{l}\text { Wolframite- } \\
\text { quartz } \\
\text { vein }\end{array}$ & W-Bi & 11 & $\begin{array}{l}\text { Wolframite; } \\
\text { Scheelite }\end{array}$ & $\begin{array}{c}\text { Devonian } \\
\text { clastic rocks }\end{array}$ & $\begin{array}{c}\text { Two } \\
\text { mica granite }\end{array}$ & $155 \pm 2.8$ & $\begin{array}{l}\text { Molybdenite } \\
\text { Re-Os }\end{array}$ & [48] \\
\hline Piaotang & Yudu, Jiangxi & $\begin{array}{l}\text { Wolframite- } \\
\text { quartz } \\
\text { vein }\end{array}$ & W-Sn & 6.9 & $\begin{array}{l}\text { Wolframite; } \\
\text { Cassiterite }\end{array}$ & $\begin{array}{l}\text { Cambrian } \\
\text { metasedimen- } \\
\text { tary }\end{array}$ & $\begin{array}{l}\text { Two } \\
\text { mica granite }\end{array}$ & $156 \pm 2.8$ & $\begin{array}{l}\text { Cassiterite } \\
\mathrm{U}-\mathrm{Pb}\end{array}$ & [49] \\
\hline Taoxikeng & $\begin{array}{l}\text { Chongyi, } \\
\text { Jiangxi }\end{array}$ & $\begin{array}{l}\text { Wolframite- } \\
\text { quartz } \\
\text { vein }\end{array}$ & W-Sn & 12.06 & $\begin{array}{l}\text { Wolframite; } \\
\text { Cassiterite }\end{array}$ & $\begin{array}{l}\text { Paleozoic } \\
\text { clastic rocks }\end{array}$ & $\begin{array}{c}\text { Biotite } \\
\text { monzogranite }\end{array}$ & $154 \pm 3.8$ & $\begin{array}{l}\text { Molybdenite } \\
\text { Re-Os }\end{array}$ & {$[50]$} \\
\hline Huameiao & Dayu, Jiangxi & $\begin{array}{l}\text { Wolframite- } \\
\text { quartz } \\
\text { vein }\end{array}$ & W & 6.7 & $\begin{array}{l}\text { Wolframite; } \\
\text { Scheelite }\end{array}$ & $\begin{array}{l}\text { Sinian } \\
\text { metasedimen- } \\
\text { tary }\end{array}$ & $\begin{array}{c}\text { Fine-grained } \\
\text { muscovite } \\
\text { granite }\end{array}$ & $158.5 \pm 3.8$ & $\begin{array}{c}\text { Molybdenite } \\
\text { Re-Os }\end{array}$ & [51] \\
\hline Huangsha & Yudu, Jiangxi & $\begin{array}{l}\text { Wolframite- } \\
\text { quartz } \\
\text { vein }\end{array}$ & W & 12.69 & $\begin{array}{l}\text { Wolframite; } \\
\text { Scheelite }\end{array}$ & $\begin{array}{c}\text { Cambrian } \\
\text { metasedimen- } \\
\text { tary }\end{array}$ & $\begin{array}{l}\text { Two } \\
\text { mica granite }\end{array}$ & $153 \pm 3$ & $\begin{array}{c}\text { Molybdenite } \\
\text { Re-Os }\end{array}$ & [52] \\
\hline Hukeng & Jiangxi & $\begin{array}{l}\text { Wolframite- } \\
\text { quartz } \\
\text { vein }\end{array}$ & W-Sn & 15.4 & $\begin{array}{l}\text { Wolframite; } \\
\text { Cassiterite }\end{array}$ & $\begin{array}{l}\text { Sinian } \\
\text { metasedimen- } \\
\text { tary }\end{array}$ & $\begin{array}{c}\text { Fine-grained } \\
\text { muscovite } \\
\text { granite }\end{array}$ & $150.2 \pm 2.2$ & $\begin{array}{l}\text { Molybdenite } \\
\text { Re-Os }\end{array}$ & [53] \\
\hline Xihuashan & Dayu, Jiangxi & $\begin{array}{l}\text { Wolframite- } \\
\text { quartz } \\
\text { vein }\end{array}$ & W & 20.7 & $\begin{array}{l}\text { Wolframite; } \\
\text { Scheelite }\end{array}$ & $\begin{array}{l}\text { Cambrian } \\
\text { metasedimen- } \\
\text { tary }\end{array}$ & $\begin{array}{c}\text { Two } \\
\text { mica granite }\end{array}$ & $157.8 \pm 0.9$ & $\begin{array}{l}\text { Molybdenite } \\
\text { Re-Os }\end{array}$ & [54] \\
\hline Zhangdou & Dayu, Jiangxi & $\begin{array}{l}\text { Wolframite- } \\
\text { quartz } \\
\text { vein }\end{array}$ & W & 4 & $\begin{array}{l}\text { Wolframite; } \\
\text { Scheelite }\end{array}$ & $\begin{array}{l}\text { Cambrian } \\
\text { metasedimen- } \\
\text { tary }\end{array}$ & $\begin{array}{l}\text { Fine-grained } \\
\text { biotite granite }\end{array}$ & $149.1 \pm 7.1$ & $\begin{array}{l}\text { Molybdenite } \\
\text { Re-Os }\end{array}$ & [44] \\
\hline Baiyunxian & $\begin{array}{l}\text { Rucheng, } \\
\text { Hunan }\end{array}$ & $\begin{array}{l}\text { Wolframite- } \\
\text { quartz } \\
\text { vein }\end{array}$ & W-Sn & 3.3 & $\begin{array}{l}\text { Wolframite; } \\
\text { Scheelite }\end{array}$ & $\begin{array}{l}\text { Sinian } \\
\text { metasedimen- } \\
\text { tary }\end{array}$ & $\begin{array}{l}\text { Fine-grained } \\
\text { biotite granite }\end{array}$ & $169.6 \pm 2.7$ & $\begin{array}{c}\text { Molybdenite } \\
\text { Re-Os }\end{array}$ & [55] \\
\hline Da'ao & $\begin{array}{l}\text { Daoxian, } \\
\text { Hunan }\end{array}$ & $\begin{array}{l}\text { Wolframite- } \\
\text { quartz } \\
\text { vein }\end{array}$ & W-Sn & & $\begin{array}{l}\text { Wolframite; } \\
\text { Cassiterite }\end{array}$ & $\begin{array}{l}\text { Sinian } \\
\text { metasedimen- } \\
\text { tary }\end{array}$ & $\begin{array}{c}\text { Fine-grained } \\
\text { biotite granite }\end{array}$ & $151.3 \pm 2.4$ & $\begin{array}{l}\text { Molybdenite } \\
\text { Re-Os }\end{array}$ & [56] \\
\hline Yaogangxian & $\begin{array}{l}\text { Chenzhou, } \\
\text { Hunan }\end{array}$ & $\begin{array}{l}\text { Wolframite- } \\
\text { quartz } \\
\text { vein }\end{array}$ & W & 20 & Wolframite & $\begin{array}{l}\text { Cambrian } \\
\text { metasedimen- } \\
\text { tary }\end{array}$ & $\begin{array}{c}\text { Fine-grained } \\
\text { two-mica } \\
\text { granite }\end{array}$ & 158 & $\begin{array}{l}\text { Cassiterite } \\
\text { U-Pb }\end{array}$ & [57] \\
\hline Dawangshan & Jiangxi & $\begin{array}{l}\text { Wolframite- } \\
\text { quartz } \\
\text { vein }\end{array}$ & W & & Wolframite & $\begin{array}{c}\text { Fine-grained } \\
\text { biotite granite }\end{array}$ & $\begin{array}{l}\text { Fine-grained } \\
\text { biotite granite }\end{array}$ & $147.6 \pm 1.8$ & $\begin{array}{l}\text { Molybdenite } \\
\text { Re-Os }\end{array}$ & [58] \\
\hline
\end{tabular}


Table 1. Cont.

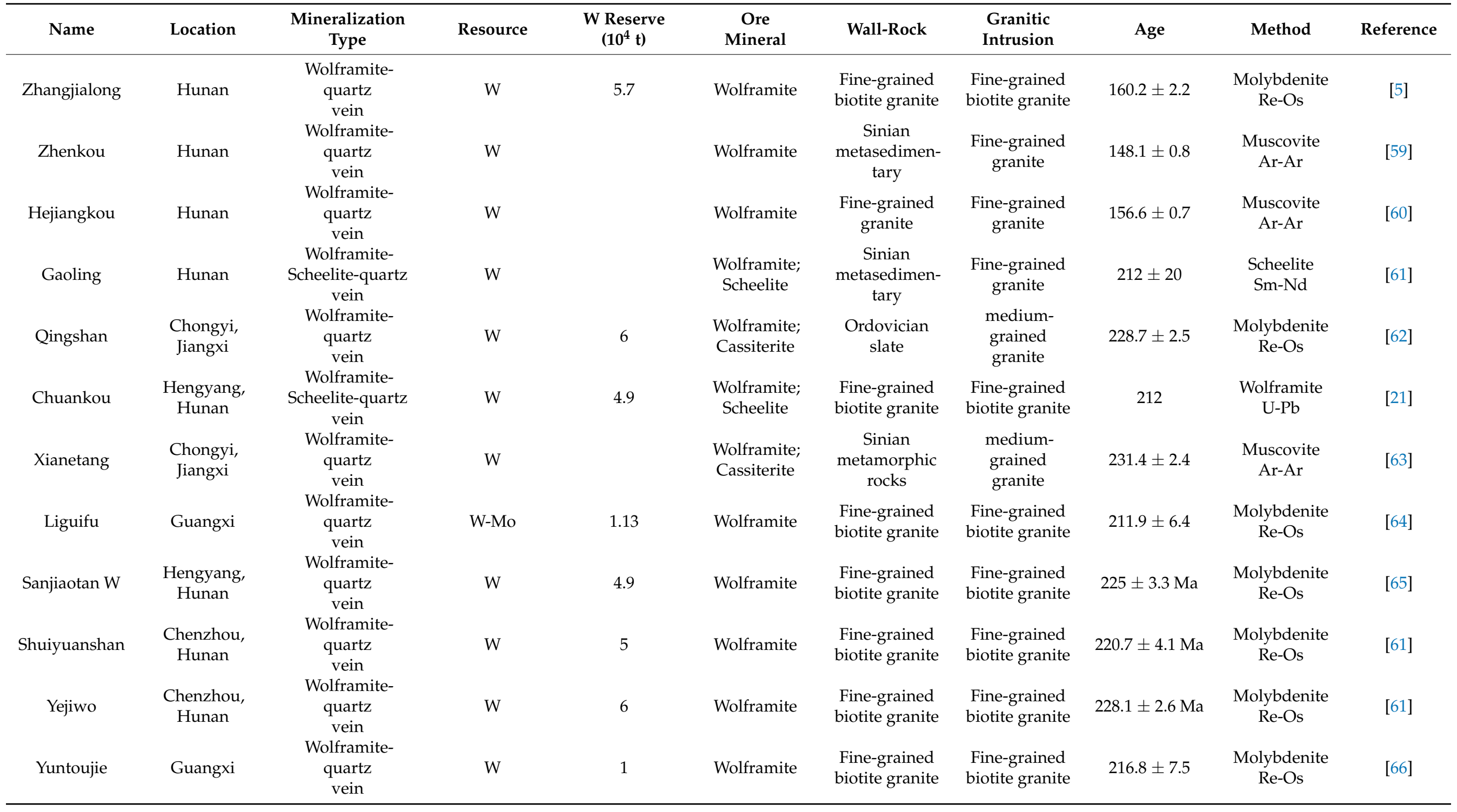


Table 1. Cont.

\begin{tabular}{|c|c|c|c|c|c|c|c|c|c|c|}
\hline Name & Location & $\begin{array}{c}\text { Mineralization } \\
\text { Type }\end{array}$ & Resource & $\begin{array}{c}\text { W Reserve } \\
\left(10^{4} t\right)\end{array}$ & $\begin{array}{c}\text { Ore } \\
\text { Mineral }\end{array}$ & Wall-Rock & $\begin{array}{l}\text { Granitic } \\
\text { Intrusion }\end{array}$ & Age & Method & Reference \\
\hline Meiziwo & $\begin{array}{l}\text { Shaoguan, } \\
\text { Guangdong }\end{array}$ & $\begin{array}{l}\text { Wolframite- } \\
\text { quartz } \\
\text { vein }\end{array}$ & W-Sn & & $\begin{array}{l}\text { Wolframite; } \\
\text { Cassiterite }\end{array}$ & $\begin{array}{l}\text { Cambrian- } \\
\text { Devonian } \\
\text { metasedimen- } \\
\text { tary }\end{array}$ & $\begin{array}{l}\text { Biotite } \\
\text { granite }\end{array}$ & $157.7 \pm 2.8$ & $\begin{array}{l}\text { Molybdenite } \\
\text { Re-Os }\end{array}$ & [67] \\
\hline Hongling & $\begin{array}{l}\text { Shaoguan, } \\
\text { Guangdong }\end{array}$ & $\begin{array}{l}\text { Wolframit- } \\
\text { Wolframite- } \\
\text { quartz } \\
\text { vein }\end{array}$ & W & & $\begin{array}{l}\text { Wolframite; } \\
\text { Scheelite }\end{array}$ & $\begin{array}{l}\text { Biotite } \\
\text { granite }\end{array}$ & $\begin{array}{l}\text { Biotite } \\
\text { granite }\end{array}$ & $159.1 \pm 1.5$ & $\begin{array}{l}\text { Molybdenite } \\
\text { Re-Os }\end{array}$ & [68] \\
\hline Yaoling & $\begin{array}{l}\text { Shaoguan, } \\
\text { Guangdong }\end{array}$ & $\begin{array}{c}\text { Wolframite- } \\
\text { quartz } \\
\text { vein }\end{array}$ & W-Sn & & $\begin{array}{l}\text { Wolframite; } \\
\text { Cassiterite }\end{array}$ & $\begin{array}{l}\text { Cambrian- } \\
\text { Devonian } \\
\text { metasedimen- } \\
\text { tary }\end{array}$ & $\begin{array}{c}\text { porphyritic } \\
\text { biotite } \\
\text { granite }\end{array}$ & $159.5 \pm 2.8$ & $\begin{array}{c}\text { Molybdenite } \\
\text { Re-Os }\end{array}$ & [67] \\
\hline Shirenzhang & $\begin{array}{l}\text { Shaoguan, } \\
\text { Guangdong }\end{array}$ & $\begin{array}{l}\text { Wolframite- } \\
\text { quartz } \\
\text { vein }\end{array}$ & W & 5.3 & $\begin{array}{l}\text { Wolframite; } \\
\text { Cassiterite }\end{array}$ & $\begin{array}{l}\text { Devonian } \\
\text { metasedimen- } \\
\text { tary }\end{array}$ & Granite & $160 \pm 2$ & $\begin{array}{l}\text { Cassiterite } \\
\text { U-Pb }\end{array}$ & [69] \\
\hline Shigushan & $\begin{array}{l}\text { Shaoguan, } \\
\text { Guangdong }\end{array}$ & $\begin{array}{l}\text { Wolframite- } \\
\text { quartz } \\
\text { vein }\end{array}$ & W-Bi & & $\begin{array}{l}\text { Wolframite; } \\
\text { Bismuthinite }\end{array}$ & $\begin{array}{l}\text { Cambrian } \\
\text { metasedimen- } \\
\text { tary }\end{array}$ & Granite & $154.2 \pm 2.7$ & $\begin{array}{c}\text { Molybdenite } \\
\text { Re-Os }\end{array}$ & [70] \\
\hline Dongping & Jiangxi & $\begin{array}{l}\text { Wolframite- } \\
\text { quartz } \\
\text { vein }\end{array}$ & W & 21.4 & Wolframite & Neoproterozoic & Granite & $132.9 \pm 1.4$ & Zircon U-Pb & [71] \\
\hline Dajinshan & $\begin{array}{c}\text { Yunfu, } \\
\text { Guangdong }\end{array}$ & $\begin{array}{l}\text { Wolframite- } \\
\text { quartz } \\
\text { vein }\end{array}$ & W-Sn & 5.27 & $\begin{array}{l}\text { Wolframite; } \\
\text { Cassiterite }\end{array}$ & $\begin{array}{l}\text { Devonian- } \\
\text { Triassic } \\
\text { metasedimen- } \\
\text { tary }\end{array}$ & $\begin{array}{c}\text { porphyritic } \\
\text { biotite } \\
\text { granite }\end{array}$ & $84.93 \pm 1.42$ & $\begin{array}{l}\text { Molybdenite } \\
\text { Re-Os }\end{array}$ & [72] \\
\hline Jubankeng & $\begin{array}{l}\text { Shaoguan, } \\
\text { Guangdong }\end{array}$ & $\begin{array}{l}\text { Wolframite- } \\
\text { quartz } \\
\text { vein }\end{array}$ & W-Sn & 12.96 & $\begin{array}{l}\text { Wolframite; } \\
\text { Cassiterite }\end{array}$ & $\begin{array}{l}\text { Cambrian- } \\
\text { Devonian } \\
\text { metasedimen- } \\
\text { tary }\end{array}$ & & $137.7 \pm 3.2$ & $\begin{array}{c}\text { Muscovite } \\
\text { Ar-Ar }\end{array}$ & [67] \\
\hline Shanhu & Guangxi & $\begin{array}{l}\text { Wolframite- } \\
\text { quartz } \\
\text { vein }\end{array}$ & W-Sn & 6.38 & $\begin{array}{l}\text { Wolframite; } \\
\text { Cassiterite }\end{array}$ & $\begin{array}{l}\text { Cambrian } \\
\text { metasedimen- } \\
\text { tary }\end{array}$ & Granite & $100.8 \pm 0.7$ & $\begin{array}{l}\text { Muscovite } \\
\text { Ar-Ar }\end{array}$ & [73] \\
\hline Xiangdong & Hunan & $\begin{array}{l}\text { Wolframite- } \\
\text { quartz } \\
\text { vein }\end{array}$ & W & 4.6 & Wolframite & $\begin{array}{l}\text { muscovite } \\
\text { granite }\end{array}$ & $\begin{array}{l}\text { muscovite } \\
\text { granite }\end{array}$ & $136.8 \pm 3.3$ & $\begin{array}{c}\text { Cassiterite } \\
\text { U-Pb }\end{array}$ & [74] \\
\hline
\end{tabular}


Table 1. Cont.

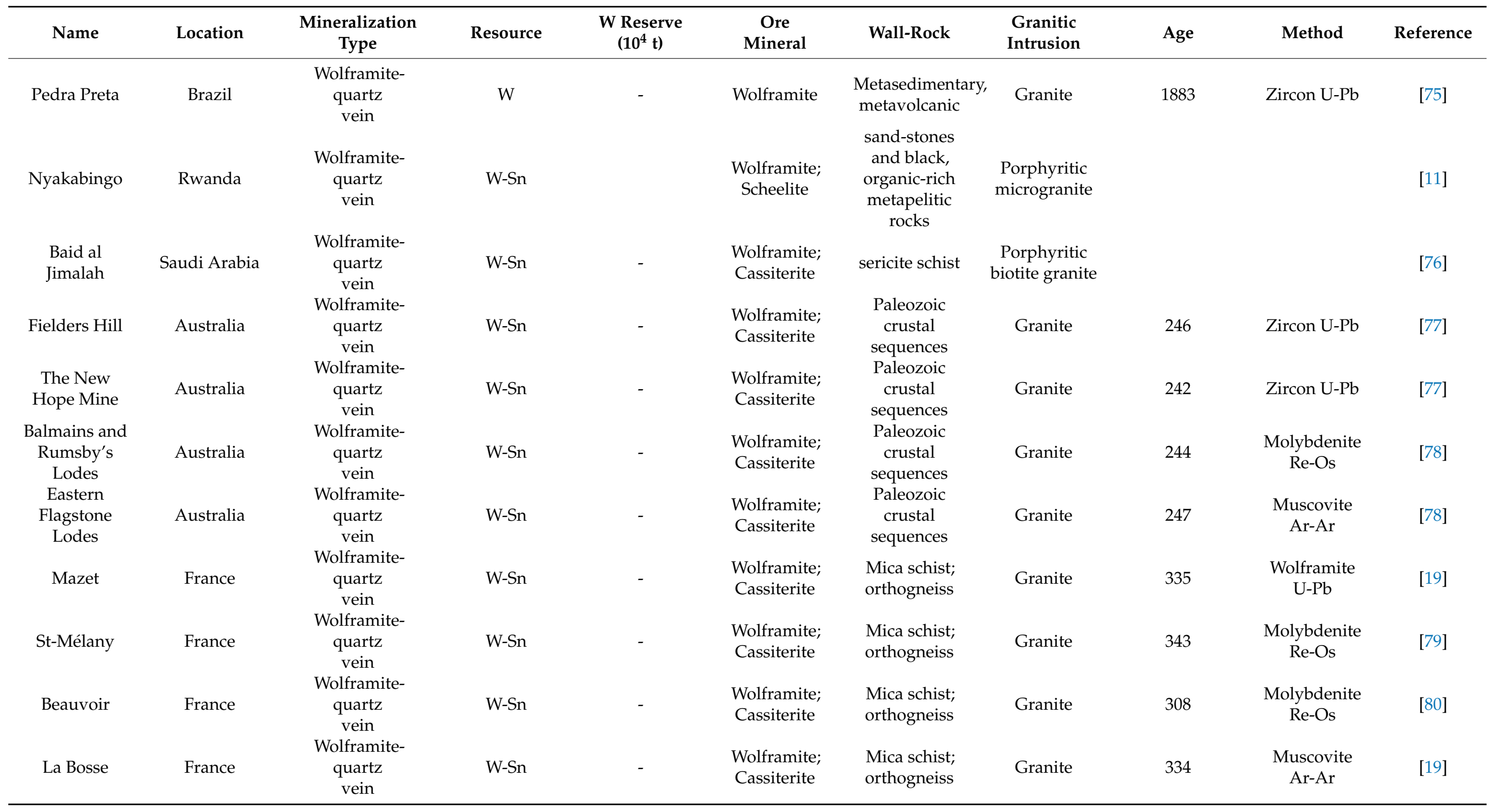


Table 1. Cont.

\begin{tabular}{|c|c|c|c|c|c|c|c|c|c|c|}
\hline Name & Location & $\begin{array}{c}\text { Mineralization } \\
\text { Type }\end{array}$ & Resource & $\begin{array}{c}\text { W Reserve } \\
\left(10^{4} t\right)\end{array}$ & $\begin{array}{c}\text { Ore } \\
\text { Mineral }\end{array}$ & Wall-Rock & $\begin{array}{l}\text { Granitic } \\
\text { Intrusion }\end{array}$ & Age & Method & Reference \\
\hline Borralha & Portugal & $\begin{array}{l}\text { Wolframite- } \\
\text { quartz } \\
\text { vein }\end{array}$ & $\mathrm{W}$ & - & Wolframite & & Granite & 280 & $\begin{array}{c}\text { Muscovite } \\
\text { Ar-Ar }\end{array}$ & [81] \\
\hline Panasqueira & Portugal & $\begin{array}{l}\text { Wolframite- } \\
\text { quartz } \\
\text { vein }\end{array}$ & $\mathrm{W}$ & - & Wolframite & $\begin{array}{l}\text { Schist, meta- } \\
\text { graywacke }\end{array}$ & Granite & 305 & Rutile U-Pb & [8] \\
\hline
\end{tabular}




\section{Multiple-Aged Granitoid and Related Wolframite-Quartz Veins}

Wolframite-quartz vein-type tungsten deposits are typically spatially associated with granitic intrusion. However, the generation of the largest deposits is often restricted to specific segments and limited periods of time. The most important vein-type tungsten resources of the world are found in the Southeast China and the Southeast Asian belt $[3,4,82,83]$ with significant resources also found in the Central Andean belt [84], the East Australian belt [85], the Mesoproterozoic Karagwe-Ankole belt [12], and the European Variscan belt [80]. Wolframite-quartz veins found in the Nanling region of south China and in the Variscan belt of Europe form an important class of $\mathrm{W}$ deposits that have contributed to the world's major W production in recent decades (Figure 1). Wolframite-quartz vein-type tungsten deposits generally occur in clusters and are formed within specific time intervals worldwide (Figure 1). The explanation of this non-uniform pattern could be key to understanding how and why metals accumulate in some places and not in others, and is therefore fundamental for mineral exploration. In this part, two typical ore clusters, i.e., the Nanling region and the Variscan belt, are selected to illustrate the characteristics of the strata, structures and granitic intrusions related to these tungsten deposits.

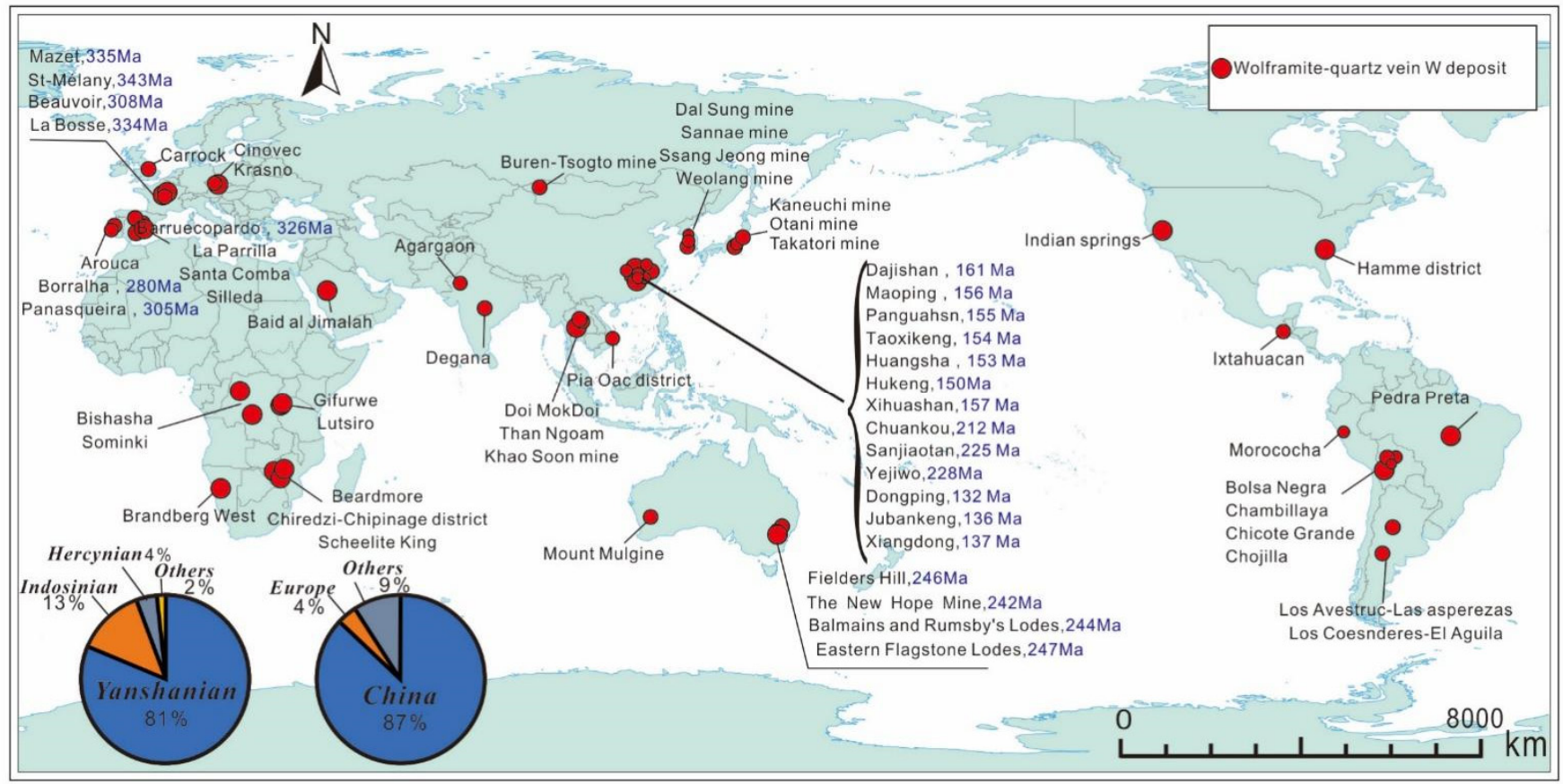

Figure 1. Global distribution of wolframite-quartz vein tungsten deposits. The distribution is shown schematically to highlight the belts and to demonstrate the diverse mineralization ages.

The Nanling region is located in the central part of Southeast China. Within an area of about $160,000 \mathrm{~km}^{2}$, the region contains several giant wolframite-quartz vein-type tungsten deposits and intense granitoid magmatism (Figure 2). The stratigraphy exposed in the Nanling region mainly includes Precambrian-Ordovician clastic rocks, Devonian-Permian carbonates, and Triassic-Cretaceous pyroclastic rocks. The strata dominated by clastic rocks are mainly distributed in the middle and east of the Nanling region, corresponding to the concentrated distribution of wolframite-quartz vein tungsten deposits (Figure 2). Multipleaged granitoid magmatism formed from the Caledonian to the Cretaceous are accompanied by syngenetic quartz vein-type tungsten mineralization of different degrees of economic significance, of which the worthiest to be proposed are those that occurred in the Triassic and Jurassic periods $[57,61,83,86,87]$. In the Triassic period (220 200 Ma), the tectonic setting of South China underwent post-collisional extension. The vein-type tungsten deposits formed at this time period were generally related to peraluminous granite magma 
triggered by crustal heating $[9,88,89]$. The Triassic wolframite-quartz vein-type deposits were previously believed to be of less economic significance due to their relatively rarer occurrences and smaller scales. In recent years, however, numerous geological research studies and exploration works have been carried out on Triassic W (-Sn) metallogenic events in South China. Liu et al. (2008) [63] reported a mica Ar-Ar age of $231.4 \pm 2.4 \mathrm{Ma}$ for the Xianetang tungsten deposit in southern Jiangxi Province. Subsequently, Li et al. (2021) [87] reported a wolframite Re-Os age of $225.5 \pm 3.6$ Ma for the Chuankou tungsten deposit in south Hunan province, which provides evidence for the existence of large-scale Indosinian quartz vein-type tungsten mineralization in the Nanling region. Although mineralization occurred occasionally from the Caledonian to the Indosinian, the most intensive emplacement of granite and the formation of cogenetic wolframite-quartz veintype tungsten deposits peaked in South China during the Yanshanian movement (Figure 2).

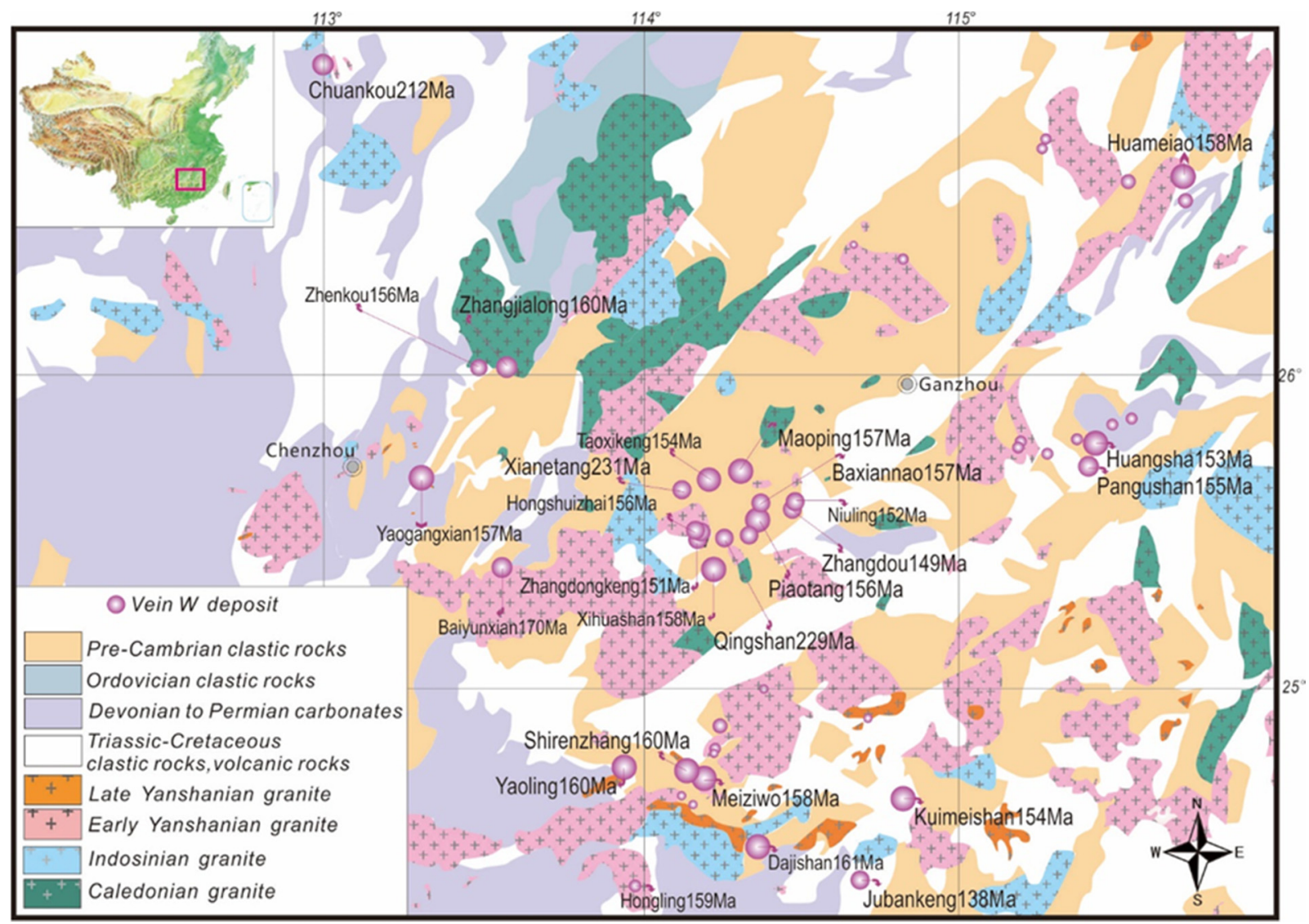

Figure 2. Simplified geologic map showing the distribution of wolframite-quartz vein tungsten deposits in the Nanling region, South China (modified after [86]).

High-precision metallogenic chronology yielded ages of 160 150 Ma for most of these vein-type tungsten deposits, although a few tungsten mineralization occurred in the late Cretaceous, such as the mineralization of the Shanhu tungsten deposit (100.2 $\pm 1.0 \mathrm{Ma}$ [90]). It is generally believed that the metallogenic background of the Yanshanian tungsten deposit is a lithospheric extensional environment controlled by the subduction of the paleo-Pacific plate $[1,57,86]$. This process led to the upwelling mantle heating of the ancient materials of the crust and the reactivation of the $\mathrm{W}$-rich part of the crust. Although the more concentrated debate still involves whether the mantle materials are involved in mineralization, the heated crustal materials formed W-rich magmas, and then these magmas experienced strong differentiation, resulting in the distribution of tungsten to later phases, and finally ore precipitation from magmatic-hydrothermal systems at favorable tectonic stratigraphic coupling sites $[3,37,57,83,86,91]$. The morphology of wolframite-quartz vein-type tungsten 
deposits is characterized by typical hydrothermal filling in tensile fractures. As a prospecting indicator, fine mica + quartz veins are often distributed at the top of the vein systems, accompanied by very little wolframite (Figure $3 \mathrm{~A}$ ). Wolframite-bearing quartz veins generally exhibit arborization and crosses in slate, granite or metasandstone, forming ore-bearing quartz veins with large width variation (Figure 3). Numerous associated sulfides, such as pyrite, arsenopyrite and chalcopyrite, were identified in the middle of the quartz vein (Figure 3C). Occasionally, hydrothermal topaz veins were identified in some deposits and occurred as the main gangue mineral rather than the common and more advantageous quartz (Figure 3D). Most wolframite crystals grow radially at the vein walls (Figure 3B,E-G), but sometimes they also occur in veins with no contact with the vein wall. Mica selvages composed mainly of muscovite and/or zinnwaldite are often sandwiched between the wall rock and quartz vein when the surrounding rock is metamorphic sedimentary rock rather than granite (Figure 3G,H). Hydrothermal alterations including sericitization, chloritization and tourmalinization in slate and sandstone generally developed within $0.5 \sim 1 \mathrm{~m}$ distance along the outer contact of both vein walls. Greisenization in the cupola of the deep granite is common in wolframite-quartz vein-type tungsten deposits.

The Variscan belt formed during the continental collision between Gondwana and Laurussia through the Upper Paleozoic, which extends across $2000 \mathrm{~km}$ from the Iberian Massif to the west and the Bohemian Massif to the east (Figure 4, [92,93]). The Variscan belt represents an important metallogenic province with world-class districts for tungsten deposits in Cornwall, the Iberian Massif, the Bohemian Massif, the Armorican Massif and the French Central Massif $[14,19,80]$. The majority of the tungsten deposits in these regions are generally related to Hercynian S-type or I-type granites which have significant W-Sn contents $[80,82,94]$.

The Bohemian is the easternmost Massif and represents a tectonic collage of several continental terranes with distinct compositional and temporal tectonostratigraphic evolution. These units in massif have been widely intruded by voluminous granitic intrusions forming strongly peraluminous S-type and slightly peraluminous A-type granite [14]. Several granite-related vein-type $\mathrm{W}$ deposits were developed in the area, such as the Zinnwald $\mathrm{Sn}-\mathrm{W}$ and the Sadisdorf Sn-W greisen-vein deposits [95,96]. LA-ICP-MS U-Pb cassiterite dating restricted these deposits to $326.1 \pm 3.4$ to $320.1 \pm 2.8 \mathrm{Ma}$ [96]. The Cornwall region, located in SW England, includes ophiolitic rocks of the Lizard Complex, which suggest proximity to a suture zone, namely the Rhenohercynian suture $[97,98]$. Numerous well-known vein-type $\mathrm{Sn}-\mathrm{W}$ mineralization are identified in the region, including the Cligga Head mine founded within the Cligga Head granite and Marazion Beach deposits linked to St. Michael's Mount granite [99]. Cassiterite U-Pb dating yielded ages from ca. 295 to $274 \mathrm{Ma}$ for Sn-W deposits in the SW England [100]. The French Massif Central hosts several vein-type W-Sn deposits that have a close spatial relation with Carboniferous granites. For example, the Vaulry deposit, located in the northwestern part of the Massif, consists of a network of NNE-trending wolframite-bearing quartz veins that crosscut the Blond granite and metamorphic rocks [101]. Three W-mineralizing episodes were reported in the French Massif Central, corresponding to the orogenic compression and emplacement of large peraluminous leucogranites (ca. 333 327 Ma), the development of late-orogenic extension and emplacement of syn-tectonic granites (ca. 317 315 Ma) and post-orogenic extension with Permian volcanism (315 310 Ma), respectively [102]. 

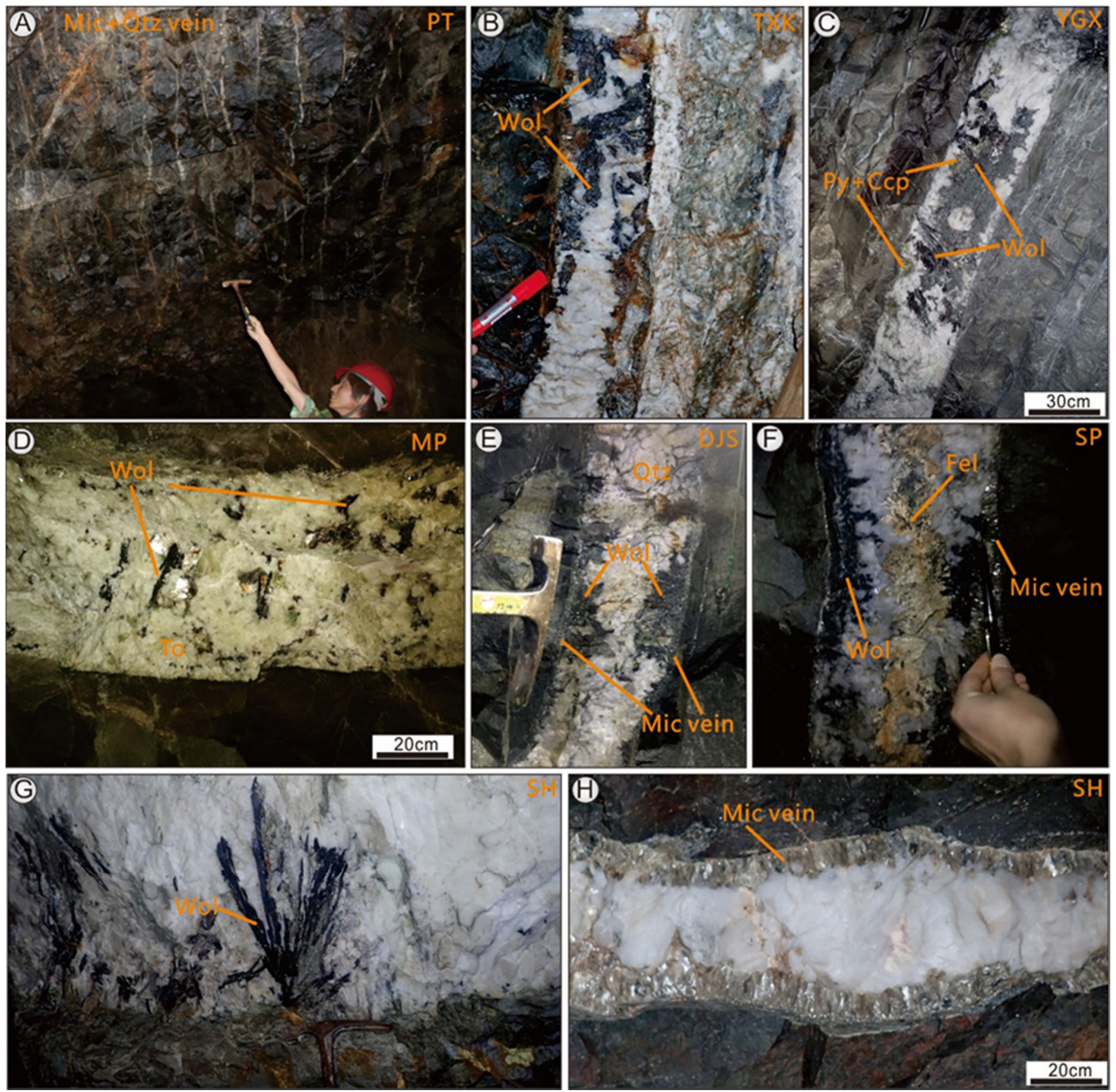

Figure 3. Representative quartz veins from tungsten deposits in South China. (A) Thin wolframitequartz vein in the Piaotang tungsten deposit. (B) Quartz vein hosted in slate from the Taoxikeng tungsten deposits. (C) Pyrite and chalcopyrite coexisting with wolframite in the Yaogangxian tungsten deposit. (D) Euhedral wolframite grain occurring in topaz from the Maoping tungsten deposit. (E) Wolframite occurring at the point of contact between quartz vein and wall-rock from the Dajishan tungsten deposit. (F) Feldspar vein hosted in the central of quartz vein from the Shangping tungsten deposit. (G) Morphology of wolframite crystals from the Shanhu tungsten deposit. (H) Quartz veins with muscovite envelopes hosted in metapelitic sandstone from the Shanhu tungsten deposit. Abbreviations: Mic-Mica; Qtz-Quartz; Py-Pyrite; To-Topaz; CcpChalcopyrite; Wol-Wolframite; Fel-Feldspar. 


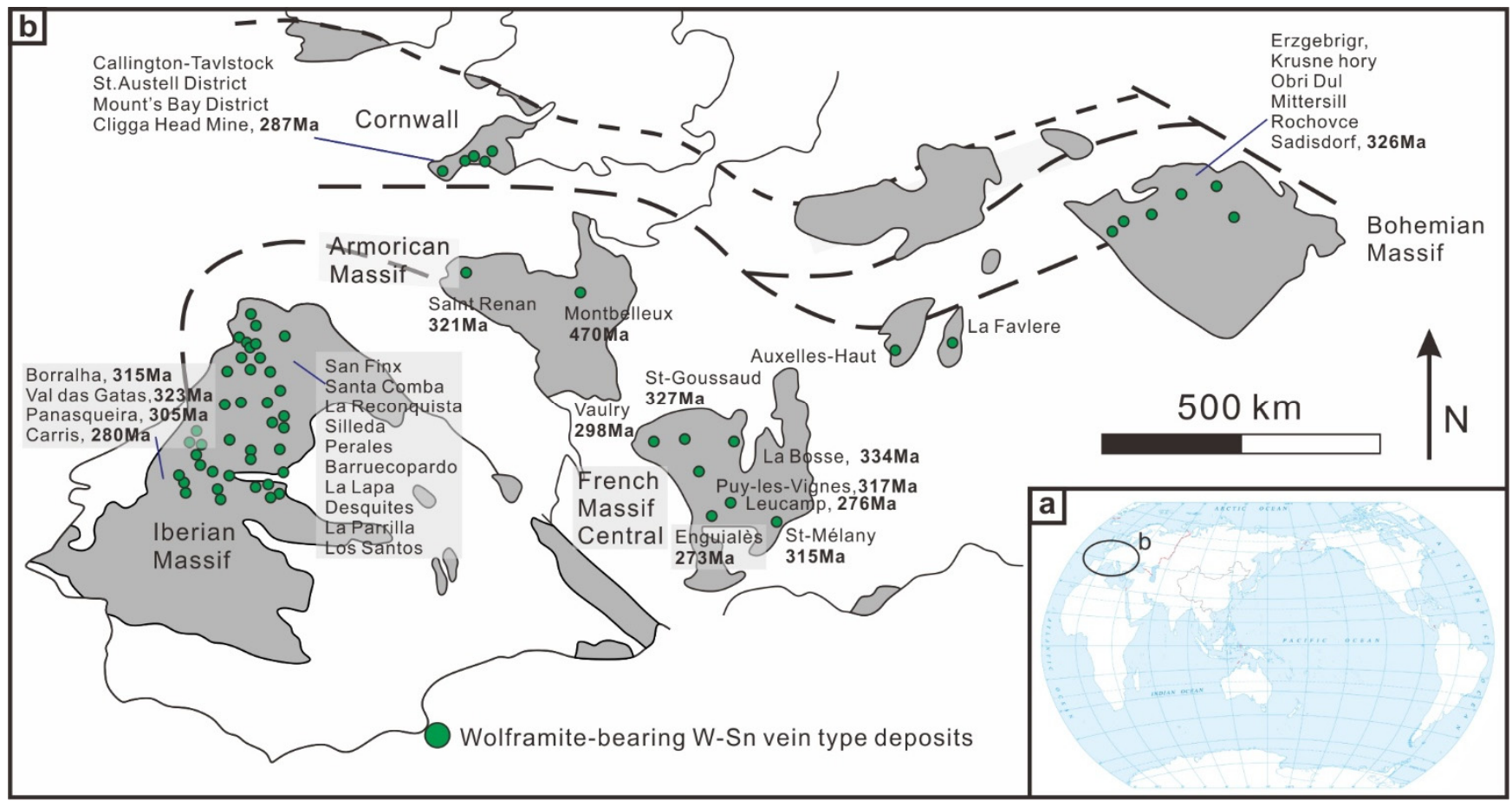

Figure 4. Simplified map showing the framework of W-Sn mineralization provinces in the Variscan belt, compiled based on the mineralization ages of selected deposits described in Table 1 (modified after [80]). Location of the European Variscan belt (a) and major occurrences of W-Sn deposit (b).

The Beira Baixa region (central Portugal), the most important tungsten mineralization province of the Variscan belt, includes several hypothermal quartz vein-type deposits containing wolframite as the chief ore mineral. These veins generally intersect Cambrian metapelites and, less commonly, cut granites. The Panasqueira W (-Sn) deposit is one of the largest tungsten deposits in Europe, and the deposit itself accounts for $79 \%$ of Portugal's total $\mathrm{W}$ reserves $(5.4 \mathrm{kt},[103])$. Densely developed wolframite-bearing subhorizontal hydrothermal quartz veins and the greisenized cupola (greisen) of a Variscan S-type granite provide the main $\mathrm{W}$ resources in Panasqueira. These quartz veins are mainly hosted in the Cambrian schist-metagraywacke complex, and are mainly composed of quartz, tourmaline, muscovite, topaz, apatite, wolframite, cassiterite and minor arsenopyrite and galena $[8,104-106]$. Rutile that coexists with wolframite yielded LA-ICP-MS U-Pb ages of $305 \mathrm{Ma}$ and this is suggested as the mineralization age for wolframite [8]. Another apatite $\mathrm{U}-\mathrm{Pb}$ age of $295 \pm 5 \mathrm{Ma}$ was obtained from wolframite-bearing quartz veins, confirming that the formation of mineralized veins occurred roughly at the Hercynian [20].

Globally, wolframite-quartz vein tungsten deposits are often restricted to specific segments and limited periods of time, which are closely related to regional tectonic movement and magmatism. The Hercynian, Indosinian and Yanshanian periods provide $90 \%$ of the global reserves, although a small amount of vein-type tungsten deposits formed during the Caledonian movement have been reported $[5,20,57,83,86]$. In addition, wolframitequartz vein-type tungsten deposits are extremely unevenly distributed worldwide, with the majority of them developed in South China (Figure 1).

\section{Nature of Ore-Forming Fluids}

Wolframite-quartz vein tungsten deposits show a close genetic relationship to magmatichydrothermal systems, which are not only the principal source for tungsten but also a heat source for mobilizing external metallogenic materials. Knowledge of the tungsten contents and physical and chemical characteristics of the ore-forming fluid is thus key to understanding the formation of this economically important class of tungsten deposits. 
Many studies have attempted to determine the characteristics of the fluids responsible for hydrothermal tungsten mineralization in quartz veins. Most of these are based on fluid inclusion and stable isotope analyses with some use of thermodynamic modeling (e.g., $[4,6,14,15,17,107-109])$. Here, we focus on the roles these fluids played in the formation of wolframite-quartz veins. We start with an evaluation of fluids recorded in ore and gangue minerals from this type of deposit worldwide and then pay attention to the significance of magmatic-hydrothermal transition fluids, as well as the role of $\mathrm{CO}_{2}$ in $\mathrm{W}$ mineralization.

\subsection{Fluids Forming Ore and Gangue Minerals}

Wolframite and quartz are undoubtedly the main ore and gangue minerals in wolframitequartz vein-type tungsten deposits. The formation sequence of these two minerals has been an enduring and critical question in terms of understanding mineralization processes. In addition to their intimate relationship observed in the field, fluid inclusions hosted in wolframite and quartz also provide evidence elucidating their deposition sequences. Before the 1980s, fluid inclusions trapped within gangue minerals, i.e., quartz and topaz, were used for the investigation of ore-forming fluids [107,110-116], with the hypothesis that the crystallization of quartz (or topaz) and wolframite occurs simultaneously. Subsequently, the application of infrared technology in the geological field provides a window for the direct testing of fluid inclusions in wolframite [22,117-121]. Since then, intensive comparative studies have been carried out on the fluid inclusion of wolframite and quartz, and the results show that the homogenization temperature of fluid inclusions in wolframite are mostly higher than those in quartz, i.e., the Dajishan, Pangushan, Piaotang and Maoping tungsten deposits from the tungsten belt in southern Jiangxi, China [4,23], the Yaogangxian, Chuankou tungsten deposit in southeastern Hunan, China [6,21] and the St. Michael's Mount and Cligga Head deposits, Cornwall, England [22]. Combining these results with the field observation that most wolframite crystals grow from the edges of quartz veins, it is suggested that most of the quartz crystals were formed after precipitation of the coexisting wolframite $[4,6,17]$.

However, the above studies are based on a more macro perspective of the mineralogical sequence, where detailed dissection of mineral precipitation and fluid entrapment sequence are generally lacking. This leads to the illusion that ore and gangue minerals are crystallized from separated hydrothermal fluids. Combined quartz cathodoluminescence and microanalytical investigations on fluid inclusions provide a powerful tool to reconstruct the detailed hydrothermal evolution in quartz. Quartz crystals containing several generations of fluid inclusions were examined in great detail by scanning electron microscope-cathodoluminescence (SEM-CL), allowing differentiation between inclusions that were trapped in diverse fluid evolution stages [17,122-125]. For wolframite-quartz vein-type tungsten deposits, Pan et al. (2019) [17] described a mineral sequence consisting of three wolframite stages and four quartz stages from a single sample of coexisting wolframite and quartz, suggesting that wolframite precipitation can be concurrent with quartz.

To further identify the fluid properties forming wolframite and quartz, published fluid inclusion salinity and homogenization temperature data from wolframite-quartz vein-type tungsten deposits worldwide were summarized (Figure 5). The dataset shows that the homogenization temperature of wolframite-hosted fluid inclusion is in the range of $250 \sim 400{ }^{\circ} \mathrm{C}$, while that of quartz is $150 \sim 350{ }^{\circ} \mathrm{C}$ (Table 2). The salinities of wolframite and quartz-hosted fluid inclusions are generally in the same range between approximately 2 and $10 \mathrm{wt} \% \mathrm{NaCl}$ equiv. It is worth noting that in those quartz vein-type deposits, which are dominated by tin, fluid inclusions containing halite daughter minerals are frequently identified, resulting in a significant increase in fluid salinity (Figure 5). In addition, the results show that wolframite and quartz have obvious overlapping areas in terms of salinity vs. homogenization temperature (Figure 5). These results may imply that the crystallization of a portion of quartz and wolframite can occur in identical fluid stages. This conclusion is also supported by mineral sequences from field observations. It is found that there are not only wolframite crystals distributed in the edge, but also some wolframite crystals 
growing in the middle of quartz veins. This probably implies that wolframite at the edge of the vein crystalized earlier, while wolframite in the middle of the quartz vein was formed contemporaneously with quartz in relatively late stages. In addition, Pan et al. (2019) [17] confirmed that late-stage wolframite fine crystals were attached to the surface of preexisting quartz crystals. In summary, we suggest that fluid inclusions in quartz can sometimes provide information on wolframite ore-forming fluids if detailed mineralogical and SEM-CL evidence are available.

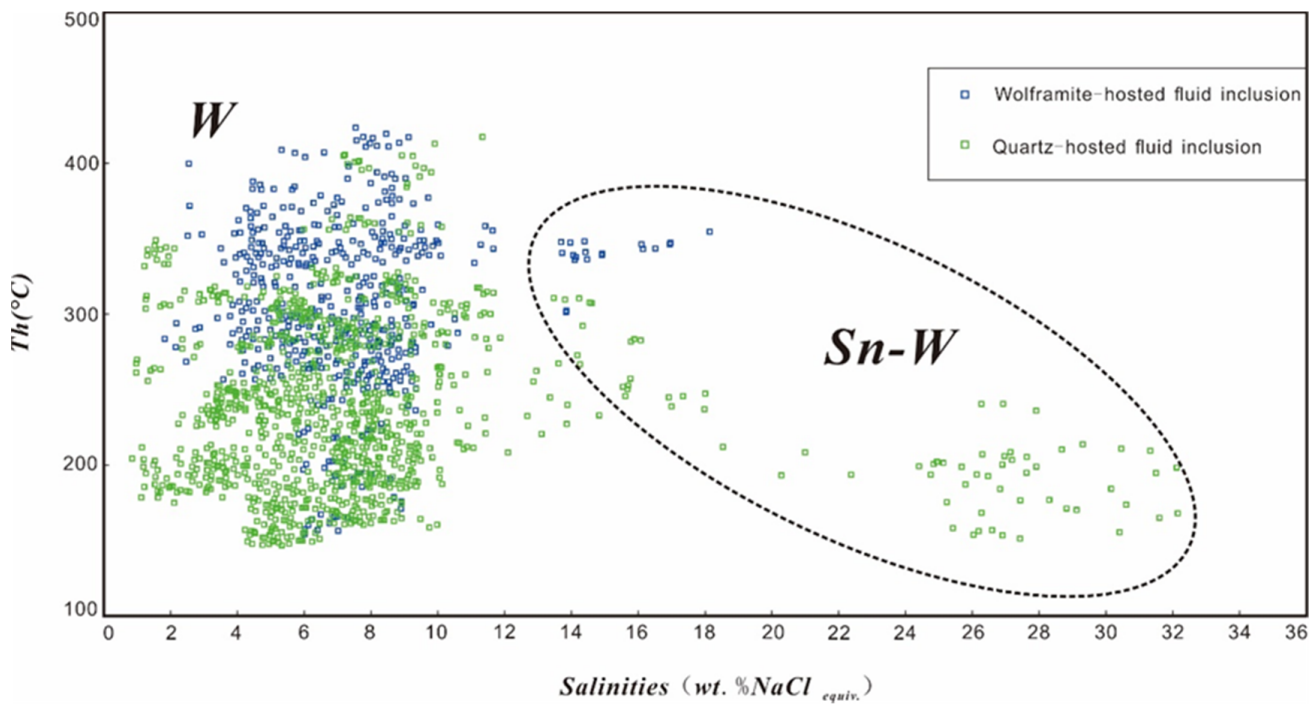

Figure 5. Homogenization temperature vs. salinity of fluid inclusions in wolframite and quartz from typical wolframite-quartz vein tungsten deposits worldwide. Note that higher salinity fluid inclusions are mostly found in Sn-dominated deposits.

Table 2. Salinity and homogenization temperature data from several wolframite-quartz vein-type $\mathrm{W}$ deposits worldwide. (I-Aqueous fluid inclusions; II- $\mathrm{CO}_{2}$-bearing fluid inclusions).

\begin{tabular}{|c|c|c|c|c|c|c|c|c|c|c|c|}
\hline Deposit & Mineral & FI & Type & Th $\left({ }^{\circ} \mathrm{C}\right)$ & Salinity & Mineral & FI & Type & $\operatorname{Th}\left({ }^{\circ} \mathrm{C}\right)$ & Salinity & Reference \\
\hline Yaogangxian & Wolframite & I & II & $280-360$ & $2.2-7.6$ & Quartz & I & II & $219-355$ & $0.2-7.3$ & [6] \\
\hline Xingluokeng & Wolframite & & I & 295-333 & $4.6-5.8$ & Quartz & & I & $237-296$ & $3.0-7.7$ & unpublished data \\
\hline Maoping & Wolframite & I & II & $293-362$ & $4.6-8.8$ & Quartz & I & II & $158-361$ & $0.4-8.1$ & [23] \\
\hline Piaotang & Wolframite & & I & $280-390$ & $4.6-8.9$ & Quartz & I & II & $171-309$ & $3.0-6.7$ & [4] \\
\hline Dangping & Wolframite & & I & $284-324$ & $6.7-8.7$ & Quartz & & I & $180-282$ & $4.5-8.5$ & [4] \\
\hline Dajishan & Wolframite & & I & $240-369$ & $4.3-9.0$ & Quartz & I & II & $170-303$ & $0.2-8.8$ & [4] \\
\hline Pangushan & Wolframite & & I & $240-366$ & $3.1-8.0$ & Quartz & I & II & $150-299$ & $0.4-7.3$ & [4] \\
\hline Xihuashan & Wolframite & & I & $300-420$ & $5.0-9.0$ & Quartz & I & II & $300-400$ & $5.0-10.0$ & [126] \\
\hline Shirenzhang & & & & & & Quartz & I & II & $206-292$ & $1.4-8.3$ & [37] \\
\hline Meiziwo & & & & & & Quartz & I & II & $196-310$ & $1.1-8.1$ & [37] \\
\hline Yaoling & & & & & & Quartz & I & II & $202-304$ & $1.2-8.9$ & [37] \\
\hline St. Michael's Mount & Wolframite & & I & $259-399$ & $1.0-18.6$ & Quartz & & I & $254-374$ & $2.1-13.5$ & [22] \\
\hline Cligga Head & Wolframite & & I & $219-380$ & $2.0-10.9$ & Quartz & & I & $193-393$ & $3.3-12.3$ & [22] \\
\hline Panasqueira & & & & & & Quartz & I & II & $200-325$ & $5.0-11.0$ & [32] \\
\hline Baxiannao & & & & & & Quartz & I & II & $150-315$ & $0.2-5.9$ & [41] \\
\hline Laoanli & & & & & & Quartz & I & II & $144-312$ & $0.2-6.7$ & [41] \\
\hline Anqiantan & Wolframite & & I & $262-375$ & $5.6-11$ & Quartz & & I & $165-253$ & $1.7-10.7$ & [127] \\
\hline Victorio Mountains & Wolframite & & I & $280-380$ & $5.4-8.9$ & Quartz & I & II & $141-320$ & $1.3-10.0$ & [108] \\
\hline San Cristobal & Wolframite & & I & $195-330$ & $1.6-6.6$ & Quartz & & I & $200-280$ & $2.7-6.1$ & [108] \\
\hline Morococha & Wolframite & & I & & & Quartz & & I & $220-384$ & $2.0-5.4$ & [102] \\
\hline Zinnwald-Cínovec & Wolframite & & I & $340-350$ & $10.0-12.0$ & Quartz & & I & $290-410$ & $1.0-9.0$ & [15] \\
\hline Baia Sprie & Wolframite & & I & $154-240$ & $4.6-6.4$ & Quartz & & I & $160-340$ & $4.5-11.3$ & [128] \\
\hline Carris & & & & & & Quartz & I & II & $136-240$ & $1-10$ & [129] \\
\hline Pedra Preta & Wolframite & & I & $270-336$ & & Quartz & I & II & $220-390$ & $0.7-7.3$ & [130] \\
\hline
\end{tabular}




\subsection{Significance of Magmatic-Hydrothermal Transition Fluids}

Most fluid inclusion studies and experimental simulations have shown that wolframite in quartz veins is crystallized from aqueous hydrothermal solutions containing salts and volatiles $[4,14,15,17,32,107]$. Moreover, the results of fluid-melt partition coefficients obtained by LA-ICPMS analysis of coexisting fluid and melt inclusions are generally in good agreement with the simulation experiments and demonstrate that tungsten strongly partitions into the fluid phase [14,131-133]. Nonetheless, a few researchers suggested that the ore-forming fluid for wolframite can be dominant in terms of melt or magmatic-hydrothermal transition fluids [38,39,134]. Huang et al. (2012) [38] proposed a melt-hydrothermal transition origin of wolframite in the Xihuashan tungsten deposit, based on the supposition that the melt inclusions hosted wolframite and beryl. Moreover, according to the crystallization experiment of tungsten in melts, it was proposed that wolframite crystals can be crystallized from flux-rich subaluminous to peraluminous melts at low temperature [39]. Alekseev et al. (2011) [135] discovered that accessory wolframoixiolite was crystalized in granitic rocks from the Chukchi Peninsula, and further inferred that tungsten can be precipitated at the earlier greisen stage. In addition, wolframite crystals can occur in greisen at the top of granitic intrusions associated with some wolframite-quartz veins. For example, there are disseminated wolframite bodies of economic significance in the Maoping tungsten deposit in the Nanling region [15]. These few thermodynamic experiments and geological phenomena seem to imply that wolframite can precipitate at the transition stage of fluid exsolution from a crystallizing melt.

Based on the statistics of the mineralization characteristics of global wolframite-quartz veins and the research results of metallogenic fluids, previous studies revealed that fluid inclusions, rather than melt inclusions, have an absolute advantage in both wolframite and associated quartz $[4,6,11,15,22,23,36,112,127,136-138]$. Although a few melt inclusions recorded in wolframite and beryl have been reported in the Xihuashan tungsten deposit, there is still a lack of research on the properties of the unclear melts captured in these inclusions. Accessory wolframite was described in granites and pegmatites from some tungsten deposits, i.e., the Yaogangxian tungsten deposit in Nanling, and the Spokoininsky and Taptanai deposits in Transbaikalia [139-141]. However, wolframite in granites and pegmatites is low in number in contrast to greisen, skarn and quartz veins, which are the main styles of hydrothermal tungsten mineralization. In addition, the attribution of wolframite crystals crystallized in greisen is still a question, because the greisenization process itself is the process of fluid metasomatism of crystallized granite. Specifically, these wolframite crystals may be formed by W-rich fluids through microcracks in granite. In conclusion, we propose that aqueous hydrothermal fluid is the tungsten-bearing media of absolute predominance responsible for wolframite-quartz veins, and the question of whether wolframite crystals can crystallize from melt or magmatic-hydrothermal transition fluid in nature still needs more integrated studies in order to be resolved.

\subsection{The Role of $\mathrm{CO}_{2}$ in $\mathrm{W}$ Transportation}

$\mathrm{CO}_{2}$ is a common volatile in magmatic hydrothermal ore deposits, e.g., porphyry $\mathrm{Cu}-$ $\mathrm{Au}-\mathrm{Mo}$, skarn $\mathrm{Cu}-\mathrm{Fe}-\mathrm{Au}$, orogenic $\mathrm{Au}$ and Sn deposits $[4,6,111,124,142]$. Similarly, a large number of studies on wolframite-quartz vein-type $\mathrm{W}$ deposits show that fluid inclusions bearing different amounts of $\mathrm{CO}_{2}$ are observed worldwide. For example, $\mathrm{Li}$ et al. (2018) [6] reported a large number of $\mathrm{CO}_{2}$-rich fluid inclusions in quartz from the Yaogangxian and Huangsha tungsten deposits in the Nanling region (Figure 6A-C). Coincidentally, the Panasqueira tungsten deposit in Western Europe also has a significant amount of volatiles dominated by $\mathrm{CO}_{2}$ in the ore-forming fluid [106]. However, it is also important to note that many other wolframite-quartz vein-type tungsten deposits do not contain $\mathrm{CO}_{2}$-rich fluids, as exemplified by the Maoping (Figure 6E), Xingluokeng (Figure 6F), Piaotang (Figure 6G) and Taoxikeng (Figure $6 \mathrm{H}$ ) tungsten deposits, all of which are large to super-large deposits. These observations have raised the following questions: What role does $\mathrm{CO}_{2}$ play in the migration and precipitation of $\mathrm{W}$ ? Furthermore, why is carbon dioxide not present in all 
wolframite-quartz vein-type $\mathrm{W}$ deposits? In order to determine its specific role in tungsten deposit formation, Higgins (1980; 1985) [107,111] carried out fluid inclusion and stable isotope research on the Grey River W deposit, a typical wolframite-quartz vein-type deposit. The results show that the fluid in the mining area has experienced a strong immiscible process characterized by loose $\mathrm{CO}_{2}$, which occurred before the precipitation of wolframite. Therefore, it is considered that the occurrence of $\mathrm{CO}_{2}$ may have facilitated wolframite's precipitation from ore-forming fluid. Moreover, experimental studies under high temperature and pressure have found that $\mathrm{CO}_{2}$ may participate in the migration and precipitation of $\mathrm{W}$. For example, Li et al. (2018) [6] carried out a dissolution and crystallization experiment of wolframite under the conditions of simulated metallogenic physicochemical conditions and controllable $\mathrm{CO}_{2}$ using a hydrothermal diamond pressure chamber. They found that the solubility of wolframite is positively related to the relative content of $\mathrm{CO}_{2}$ in the system. In addition, by establishing the reaction equilibrium model of the W-Fe-Cl-Na-O-C-H system, Liu and Zhang, (2019) [143] proposed that $\mathrm{CO}_{2}$ escape caused by depressurization can induce a decrease in tungsten solubility of $27 \sim 47 \%$. Therefore, this process may be one of the key mechanisms of wolframite precipitation. The above studies emphasize that $\mathrm{CO}_{2}$ may have effects on tungsten solubility, and thus may play an important role in the precipitation of wolframite and other minerals.

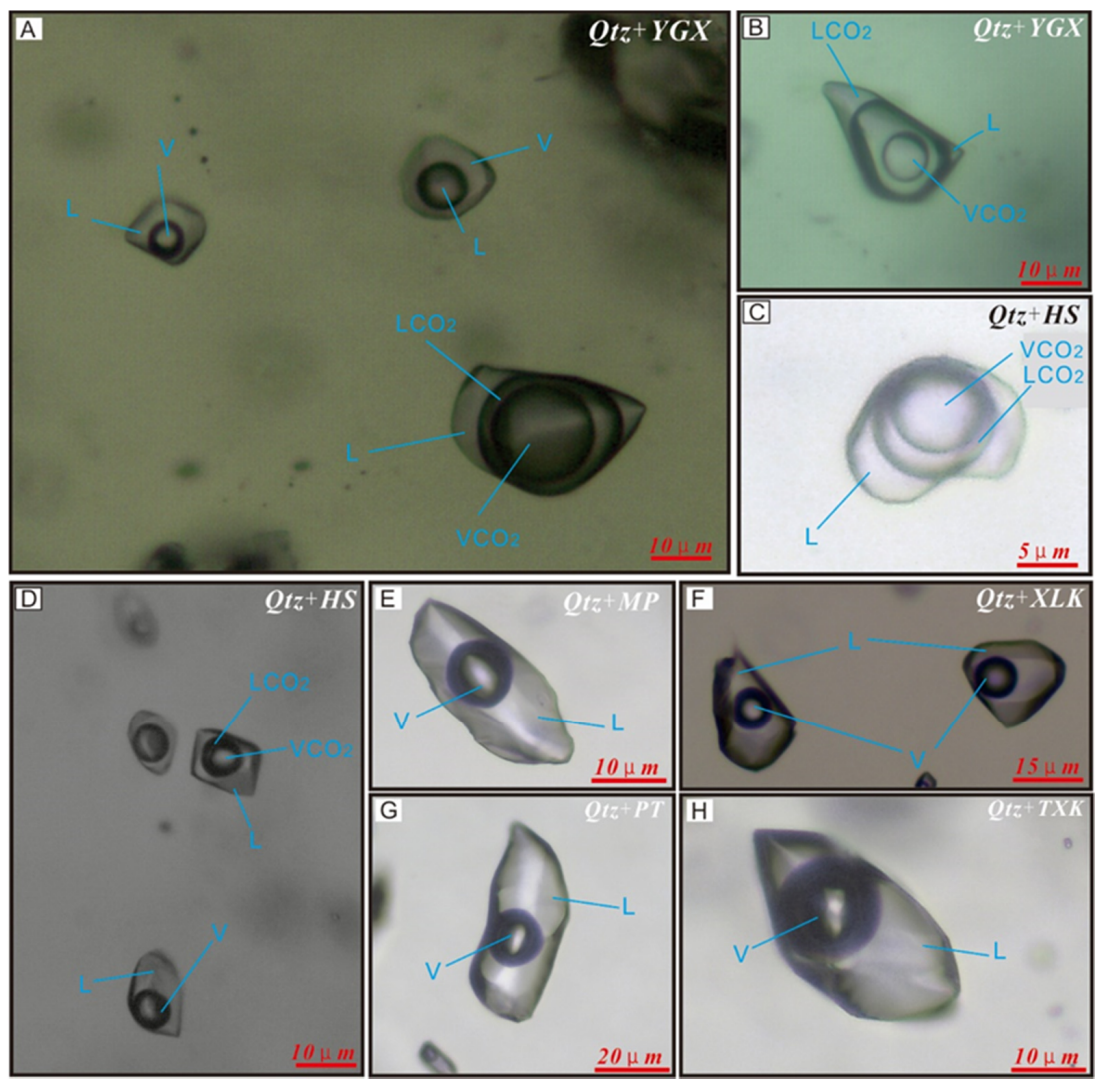

Figure 6. Representative fluid inclusions captured in quartz from wolframite-quartz vein-type tungsten deposits in South China. $\mathrm{CO}_{2}$-bearing inclusion coexisting with liquid-rich aqueous inclusions in the Yaogangxian (A) and Huangsha tungsten deposit (D). (B) Typical three-phase fluid inclusions in quartz generally consist of liquid $\mathrm{CO}_{2}$, gas $\mathrm{CO}_{2}$ and a small amount of aqueous solution, respectively (the Yaogangxian tungsten deposit). (C) $\mathrm{CO}_{2}$-bearing inclusion in the Huangsha tungsten deposit. (E-H) Two-phase aqueous inclusions in the Maoping (E), Xingluokeng (F), Piaotang (G) and Taoxikeng (H) tungsten deposits, respectively. Abbreviations: Qtz-Quartz; YGX-Yaogangxian; HS—Huangsha; MP-Maoping; PT—Piaotang; XLK—Xingluokeng; TXK—Taoxikeng; L-liquid; $\mathrm{V}$-vapor; $\mathrm{LCO}_{2}$-liquid $\mathrm{CO}_{2} ; \mathrm{VCO}_{2}$-vapor $\mathrm{CO}_{2}$. 
Despite the above mentioned studies, it is very important to note that the knowledge of $\mathrm{CO}_{2}$-rich fluid's occurrence in tungsten deposits is based mostly on observations of quartzhosted fluid inclusions. However, through the infrared microscope observation of wolframite in the Cornwall vein-type tungsten deposit, Campbell and Panter (1990) [22] found that wolframite-hosted fluid inclusions are not rich in $\mathrm{CO}_{2}$. Similarly, Luder (1996) [118] carried out infrared research on wolframite-hosted fluid inclusions in Panasqueira, and no inclusions containing $\mathrm{CO}_{2}$ were found. In South China, Ni et al. (2015) [4] conducted fluid inclusion research on typical wolframite-quartz vein-type tungsten deposits in several deposits in Southern Jiangxi, such as the Xihuashan, Dajishan and Pangushan deposits, and also found that only aqueous inclusions were observed in wolframite. Recently, similar views have been supported by fluid inclusion investigations from the Yaogangxian, Maoping, Xingluokeng, Piaotang and Taoxikeng tungsten deposits in South China (Figure 7). Although small amounts of $\mathrm{CO}_{2}$ were revealed by microthermometry in wolframite-hosted fluid inclusions at some of these deposits such as Yaogangxian [6] and Maoping [23], there is, in general, a lack of immiscible assemblage.

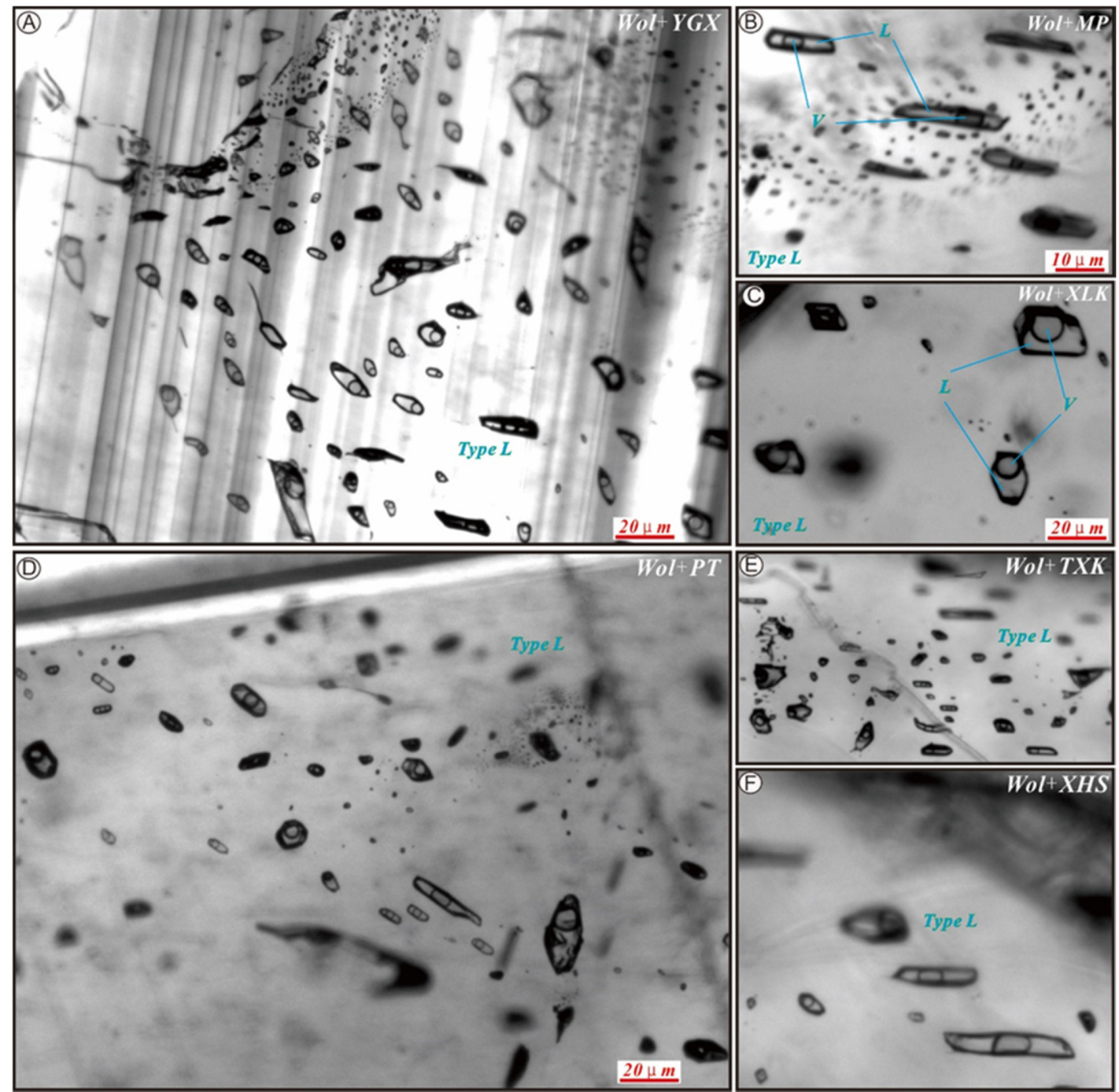

Figure 7. Photomicrograph of representative fluid inclusions captured in wolframite from wolframitequartz vein-type tungsten deposits in South China. Pictures show typical two-phase liquid-rich fluid inclusion assemblages in wolframite from the Yaogangxian (A), Maoping (B), Xingluokeng (C), Piaotang (D), Taoxikeng (E) and Xihuashan (F) tungsten deposits, respectively. Abbreviations: Wol-Wolframite YGX-Yaogangxian; MP-Maoping; XLK—Xingluokeng; PT_Piaotang; TXKTaoxikeng; XHS—Xihuashan; L-liquid; V-vapor. 
To better evaluate the role of $\mathrm{CO}_{2}$ in ore-forming fluids, we compiled the existing fluid inclusion data from wolframite-quartz vein-type tungsten deposits all over the world (Table 2). There are 18 case studies that provide direct information on ore-forming fluids from wolframite-hosted fluid inclusions $[4,6,15,22,23,58,130,136,137,139]$. It is noteworthy is that only four of these deposits show the existence of a small amount of $\mathrm{CO}_{2}$ in wolframite-hosted fluid inclusions. The rare occurrence and low abundance of $\mathrm{CO}_{2}-$ rich fluid inclusions observed in wolframite crystal are interpreted, therefore, to indicate wolframite's precipitation from $\mathrm{CO}_{2}$-poor hydrothermal fluid. In addition, studies of oreforming fluids of many wolframite-quartz vein-type tungsten deposits show that even gangue minerals such as quartz do not contain observable $\mathrm{CO}_{2}$ (Figure $\left.6 \mathrm{E}-\mathrm{H}\right)$. The experimental simulation of wolframite solubility also found that the migration of tungsten is achieved predominantly by tungstate species, and thus, tungsten-chloride, tungstenfluoride or tungsten-carbonate complexes are not required for W transport [144]. Therefore, it is considered that $\mathrm{CO}_{2}$-free aqueous solution is sufficient for effective wolframite transportation and precipitation $[11,36,112,138]$. In conclusion, we propose that although $\mathrm{CO}_{2}$ may have some indirect influence on tungsten's solubility, the existence of $\mathrm{CO}_{2}$ is essentially not necessary for effective wolframite mineralization in vein-type tungsten deposits.

\section{Wolframite Precipitation Mechanism}

The tungsten precipitation from hydrothermal fluid is the key process that occurs during the formation of an economic $W$ deposit. The solubility experiment and thermodynamic simulation of wolframite show that tungsten mainly migrates in the form of simple tungstic acid $\left(\mathrm{H}_{2} \mathrm{WO}_{4}, \mathrm{HWO}_{4}{ }^{-}, \mathrm{HWO}_{4}{ }^{2-}\right)$ and alkaline tungstate ion pairs $\left(\mathrm{KHWO}_{4}\right.$, $\mathrm{NaHWO}_{4}, \mathrm{KWO}_{4}{ }^{-}, \mathrm{NaWO}_{4}$ ) in hydrothermal systems [144]. The solubility of tungstic acid or tungstate in hydrothermal solution is mainly affected by temperature, salinity, $\mathrm{pH}$, oxygen fugacity and the activity of cationic precipitants (Fe, Mn) [144,145]. Therefore, the change of any of the above factors will lead to the instability of tungsten complexes in fluid, resulting in the precipitation of wolframite. Here, several prevailing mechanisms for wolframite deposition proposed in the literature are summarized and discussed.

Based on a large number of comprehensive research studies, the widely accepted precipitation mechanism of wolframite in quartz vein includes fluid boiling or immiscibility, fluid-rock interaction, simple cooling and meteoric water mixing $[4,6,13,15,17,21,111,144,146-148]$. However, which precipitation mechanism plays the key role in certain $\mathrm{W}$ deposits formation has been a matter of dispute for decades. The experimental simulation study shows that the solubility of wolframite is greatly affected by temperature between approximately 300 and $350{ }^{\circ} \mathrm{C}$ [149]. Therefore, the simple cooling of $\mathrm{W}$-bearing magmatic hydrothermal solution is an efficient mechanism for wolframite precipitation [145,150]. In studies of wolframitehosted fluid inclusions from South China, it was found that the direct ore-forming fluids belong to the $\mathrm{H}_{2} \mathrm{O}-\mathrm{NaCl}$ system, and a macroscopic cooling process was recorded based on the microthermometric measurement of many deposits $[4,6,45]$. These thermodynamic experiments and fluid inclusion analyses support the dominance of simple cooling as the main mechanism of wolframite precipitation.

As mentioned in the previous section, $\mathrm{CO}_{2}$-bearing fluid inclusions are abundant in associated gangue minerals such as quartz (Figure $6 \mathrm{~A}-\mathrm{C}$ ), and thus, fluid immiscibility characterized by $\mathrm{CO}_{2}$ discharge is proposed as an important mechanism of tungsten mineralization [111,146]. Based on the analysis of single-fluid inclusions in both wolframite and coexisting quartz, Korges et al. (2018) [15] proposed that fluid boiling triggered by decompression plays a key role in the precipitation of wolframite. Thermodynamic simulation studies show that the escape of acid gaseous components caused by fluid boiling/immiscibility will lead to the increasing of fluid $\mathrm{pH}$, thus reducing the solubility of wolframite and causing wolframite precipitation [10,107,144,151]. Recently, Pan et al. (2019) [17] dissected the multi-stage fluid evolution process of the Yaogangxian W deposit in the Nanling region, and found that the ore-forming fluid of later-stage wolframite is mainly characterized by the significant loss of $\mathrm{CO}_{2}, \mathrm{CH}_{4}, \mathrm{~B}, \mathrm{As}$ and $\mathrm{S}$. It is therefore proposed that 
the loss of acidic gases caused by fluid immiscibility is accompanied by a certain stage of wolframite precipitation in the Yaogangxian tungsten deposit.

Changes of the activity of cationic precipitants is also important for $\mathrm{W}$ mineralization given that $\mathrm{Fe}$ and $\mathrm{Mn}$ are indispensable materials for wolframite formation. Via a geochemical analysis of both fluid inclusion and wall rock, Lecumberri-Sanchez et al. (2017) [13] proposed that the addition of Fe provided by fluid-rock interaction is the main controlling factor of wolframite precipitation at Panasqueira, Portugal. Similarly, quantitative analysis of fluid inclusion and wall rock alteration suggest that wall rocks are possible sources of Fe required for the precipitation of wolframite in the Chuankou tungsten deposit, South China [21]. On the contrary, Yang et al. (2019) [16] reported very high Mn (up to $6.7 \mathrm{wt} \%$ ) and $\mathrm{Fe}$ (up to $44.4 \mathrm{wt} \%$ ) concentrations in quartz-hosted fluid inclusions from the Piaotang deposit in southern Jiangxi and suggested that the magmatic-hydrothermal fluids themselves contain enough $\mathrm{Fe}$ and $\mathrm{Mn}$ for wolframite deposition. However, the reported Fe and Mn concentrations in the study of Yang et al. (2019) [16] are too high to be true given that the measured fluid inclusions are all two-phase aqueous inclusions of low salinity (5.0 $\mathrm{wt} \% \mathrm{NaCl}$ equiv.). In summary, fluid-rock interaction may be a major controlling factor for the selective occurrence of wolframite-bearing quartz veins in some strata, i.e., Fe-rich metasediments. However, this seemingly does not explain the occurrence of many wolframite-quartz vein deposits that are hosted entirely in granite, such as some of the deposits in the Xihuashan-Zhangtiantang ore district in Nanling region.

The addition of meteoric water is occasionally used to explain the precipitation of wolframite (e.g., $[137,148])$. However, the major evidence is often provided by mineral bulk H-O isotopes, which are usually affected by secondary fluid inclusions [101,152]. Previous studies on wolframite-hosted inclusions from most $\mathrm{W}$ deposits confirm that the salinity of ore-forming fluids is relatively consistent during wolframite deposition and does not decrease with temperature $[4,6,17,23]$. These results suggest that fluid mixing, although frequently recorded in late stage quartz, is not primarily responsible for large-scale wolframite precipitation.

In conclusion, the precipitation mechanism of wolframite ore is still subject to much dispute, with proposed mechanisms that include boiling, simple cooling, fluid-rock interaction and meteoric water mixing. For the former three mechanisms, wolframite precipitation is caused by changing fluid parameters (temperature, $\mathrm{pH}$, etc.) or element concentrations in fluid, which can result in a significant decrease in W solubility. On the contrary, meteoric water mixing or dilution alone do not seem to be effective approaches to reduce W's solubility in hydrothermal fluids and are not suggested by fluid inclusion evidence from wolframite. Therefore, we propose that the precipitation of wolframite is mainly affected by simple cooling, fluid boiling, and fluid-rock interaction, whereas fluid mixing may not be an effective precipitation mechanism for the formation of giant wolframite-quartz vein-type tungsten deposits.

\section{Ore-Forming Fluid Sources}

A close temporal and spatial relationship generally exists between the wolframitequartz vein-type tungsten deposits and granitic intrusion. However, the genetic link between granitic magma and associated wolframite-bearing quartz veins is still controversial (e.g., $[5,11,16,21,23,74,80,153,154])$. Two well-known genetic models have been proposed: The "orthomagmatic hypothesis" emphasizes that granitic magma is the direct source of W-bearing fluid, and ore-forming fluid is directly separated during the cooling and crystallization of granitic magma $[11,80,85,155]$. The "circulation hypothesis" holds that granitic magma provides a heat source to drive the convective circulation of external fluid (such as metamorphic fluid and meteoric water) from host rocks, which causes ore materials to be leached from wall rock (metamorphic sedimentary rocks) and enriched in fluid $[101,156]$. From the above two controversial genetic models, it can be seen that the source of ore-forming fluid responsible for wolframite-quartz vein-type tungsten deposits is still in dispute. 
The study of fluid inclusions and stable isotopes provides the main medium for tracing the source of ore-forming fluid. Previous studies on $\mathrm{H}$ and $\mathrm{O}$ isotopes and fluid inclusions show that the ore-forming fluid in the main mineralization stage of wolframite-quartz vein-type deposits has a magmatic origin $[4,6,11,23,80,85]$, and diverse degrees of meteoric water mixing in the late stage were reported [6,33,35,152]. Recently, Korges et al. (2018) [15] analyzed the composition of individual inclusions at different mineralization stages of the Zinnwald Sn-W deposit and found that the ratio of incompatible elements such as Cs and $\mathrm{Rb}$ in the fluid remain almost unchanged, which suggests a single sourced magmatic fluid. Similar results were obtained from fluid inclusions hosted by coexisting wolframite and quartz at the Yaogangxian $\mathrm{W}$ deposit and indicate a consistent magmatic-hydrothermal origin [17]. It is worth noting that some $\mathrm{W}$ deposits also show metamorphic fluids being involved in the metallogenic process of wolframite [101,130]. For example, the study of the Vaulry W (-Sn) deposit in France suggests that the ore-forming fluid is either a true metamorphic fluid or a surface-derived fluid that was deeply equilibrated with the granitic basement [101]. Similarly, the large amount of $\mathrm{CO}_{2}$ and $\mathrm{CH}_{4}$ in the ore-forming fluid of the Pedra preta $\mathrm{W}$ deposit in Brazil implies a possible reductive metamorphic fluid from shallow metamorphic surrounding rock [130]. By analyzing the ore-forming fluid of the Yaogangxian tungsten deposit, Pan et al. (2019) [17] proposed that the true oreforming fluid corresponding to wolframite precipitation is enriched in $\mathrm{Sr}$ and $\mathrm{Ca}$, which may indicate the addition of $\mathrm{Sr}$ and $\mathrm{Ca}$ from sedimentary water.

In addition, it is still controversial as to whether mantle-derived materials were involved in the ore-forming fluid of wolframite-quartz vein-type $W$ deposits. Traditional views suggest that granites related to $\mathrm{W}$ mineralization are typical S-type granites derived from continental crust remelting [57,157-161]. This means that the large-scale ore-forming fluid mainly comes from the crust. With the application of He-Ar isotopes in the tracing of fluid sources [162-165], studies of He and Ar homologues of some typical wolframitequartz vein-type tungsten deposits have shown that mantle-sourced fluids are involved in the mineralization process $[3,129,164,166]$. On the contrary, the He-Ar isotopic results of some W deposits such as Piaotang [167], Tieshanlong [168] and Maoping [45] suggest that the ore-forming fluid is mainly crustal-derived without the obvious participation of mantle-derived fluid. Therefore, the issue of whether or not mantle-derived materials are involved in the ore-forming process of wolframite-quartz veins and, if so, the nature of their role is worth further discussion.

\section{Wolframite-Quartz Veins and Their Parental Granite}

Reconstructing the genetic model of wolframite-quartz vein-type tungsten deposits is critical for understanding their genesis and for the development of prospecting strategies within known ore districts and metallogenic provinces. Wolframite-bearing quartz veins commonly show zonings of different mineralization forms in the vertical direction (Figures 8 and 9). A general pattern of vein morphology from the bottom to the top is concluded as the "Five-floors" model, which suggests that vein thickness is commonly reduced with the increasing of the distance from the associated granitic intrusion. This pattern is particularly true in the Nanling region for both steeply (Figures 8A and 9) and gently dipping veins (Figure 8B, [23]). In most cases, wolframite-quartz veins are rooted from the cupola of the deep-seated granite and can sometimes extend into the granite for limited distances (Figure 8B). In rare cases, the expected granite is not revealed (e.g., Figure 8A), implying its occurrence at greater depth. Where granite is encountered, disseminated $\mathrm{W}$ (-Sn) mineralization, which is associated with greisenization, is commonly developed at the roof of the intrusion (Figures 8B and 9). The coupling model of the two mineralization styles has guided the exploration of a large number of tungsten deposits and the selection of mining targets in the Nanling region [69,169]. A few recent studies provided geochronology and fluid evidence for a genetic link between wolframite-quartz veins and the greisen type mineralization. For example, cassiterite $\mathrm{U}-\mathrm{Pb}$ ages and trace element compositions obtained from both wolframite-bearing quartz veins hosted in Cambrian metamorphic rocks and 
the disseminated W-Sn mineralization in granite at the Maoping tungsten deposit of South China suggest the contemporaneous formation from the same hydrothermal system $[23,45]$. Similarly, the Sn-W Zinnwald deposit in Erzgebirge (Germany and Czech Republic) shows greisen type Sn mineralization in granite, which shares the same fluid origin and properties with W-Sn mineralization in subhorizontal wolframite-bearing quartz veins [15].

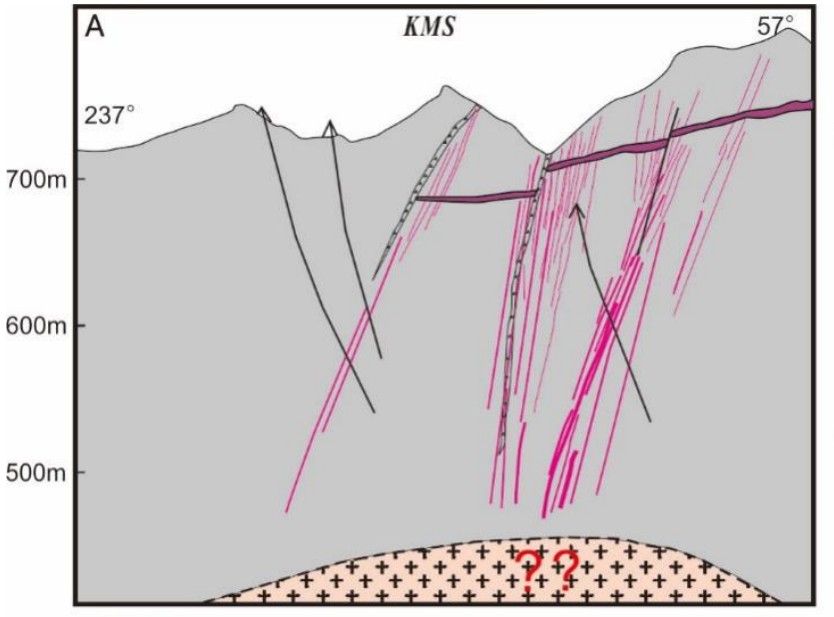

$\left[\begin{array}{l}{ }^{+}++ \\ ++\end{array}\right.$

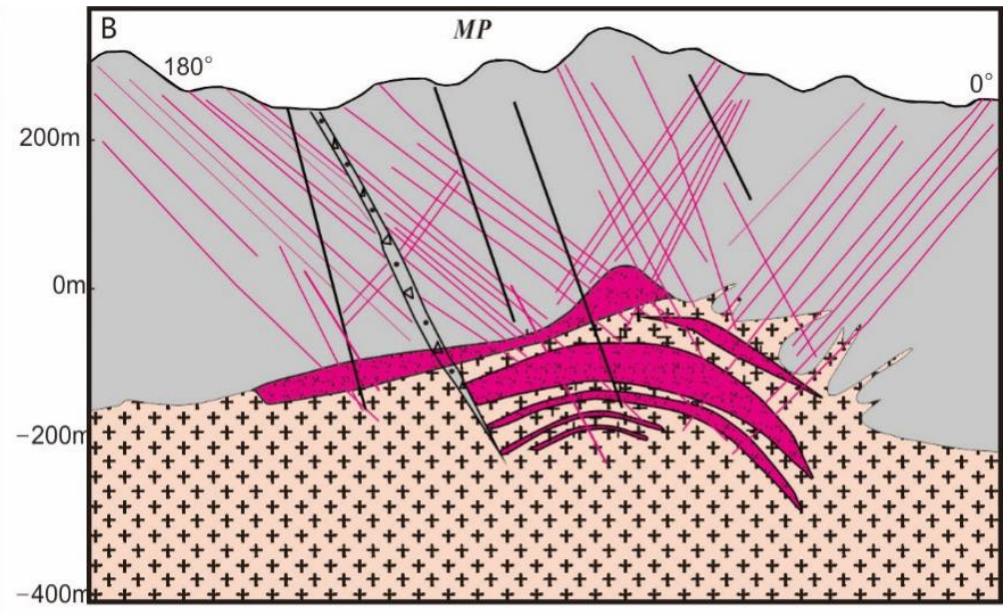

Skarn $W$ mineralization

Wolframite-quartz vein

Fracture zone

Disseminated $W$ deposit $\backslash$ Drill holes

Figure 8. (A) Cross section of the Kuimeishan tungsten deposit, the occurrence of the granite underneath is inferred from limited drill cores. (B) Cross section of the Maoping quartz vein system, greisen (cupola) and Maoping granite (modified after [23]).
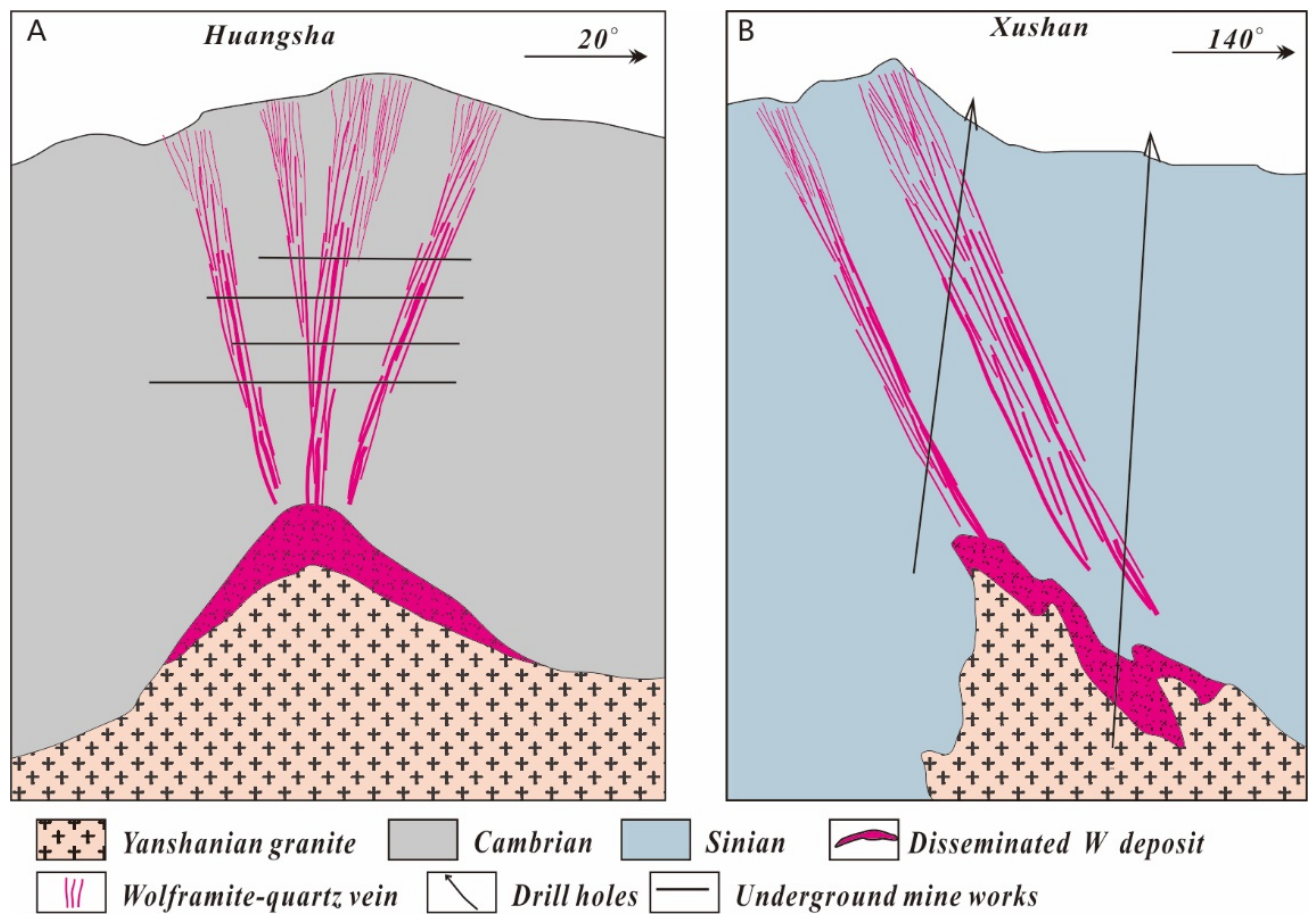

Figure 9. Cross sections of the Huangsha and (A) Xushan (B) tungsten deposits, both showing the spatial relationship between veins, greisen and granitic intrusions (modified after [23]). 
The determination of genetic links between wolframite-quartz veins and their spatially associated granite has been a controversial issue in some deposits. Recent geochronological studies show that some spatially associated granites may only serve as wall rocks, rather than as parental rocks providing materials and ore-forming hydrothermal fluids. For example, based on the Ar-Ar age of muscovite (153 Ma) related to the disseminated mineralization in granite and the Re-Os age of molybdenite (160 Ma) in quartz veins, Yuan et al. (2018) [5] proposed that different tungsten mineralization scenarios in the Zhangjialong tungsten deposit were the result of Yanshanian magmatism, despite the fact that spatially associated granite was emplaced in the Caledonian. In addition, according to the high-precision muscovite Ar-Ar dating of the Zhenkou tungsten deposit, Yang et al. (2019) [16] suggested that wolframite-bearing veins were formed in Late Jurassic, and have no genetic connection with the spatially associated Penggongmiao granite of the Early Paleozoic. Similarly, hydrothermal zircon, high-precision cassiterite U-Pb, molybdenite Re-Os and muscovite Ar-Ar data also show that the Xitian and Dengfuxian tungsten mineralization are related to early Yanshanian granite intrusion rather than Indosinian granite [60,170,171]. Recently, a U-Pb age of wolframite (212 Ma) was reported in the large-scale Chuankou W deposit; it was found to be more than 15 Ma younger than the associated granitic intrusion (227 237 Ma, [21]). These geochronological results suggest the existence of syn-ore concealed granite at greater depth and, thus, the exploration potential for disseminated $W$ mineralization at these depths [21]. To sum up, we suggest that more attention should be paid to the relationship between wolframite-quartz veins and spatially associated granite. Geochronology and fluid source evaluation can provide key evidence for verifying their genetic link and, in turn, can guide mineral exploration and targeting.

The Zhangtiantang-Xihuashan ore belt, located in the south of Jiangxi Province, is characterized by more than 10 middle- to large-scale wolframite-quartz vein-type $W$ deposits distributed at nearly equal intervals in space (Figures 10 and 11, [172]). It is noteworthy that these wolframite-quartz veins, of considerable economic value, were developed at similar elevation ranges despite the fact that the emplacement depth of associated granitic intrusions can vary significantly (Figure 11). High-precision molybdenite Re-Os along with cassiterite and wolframite U-Pb ages indicate that these deposits were formed in a very limited time intervals between $155 \mathrm{Ma}$ and $159 \mathrm{Ma}[45,54,173,174]$, which are indistinguishable from the granite zircon U-Pb ages of $152 \mathrm{Ma}$ to $159 \mathrm{Ma}[49,175]$ at the given analytical precision. Moreover, fluid inclusion analysis showed that these deposits share similar homogenization temperatures and salinity levels, indicating that they are likely controlled by a regional-scale magmatic-hydrothermal event (Figure 12). Since some granite types are exposed to the surface and host wolframite-quartz veins, such as those of the Xihuashan, Dangping and the Zhangtiantang areas, whereas other tungsten deposits are mainly hosted in the metasediments, this may suggest that the currently known granite types are not the direct parental granites for $\mathrm{W}$ mineralization even though their ages are indistinguishable. This is supported by the discussion in the previous paragraph. We propose that an as-yet undiscovered deep intrusion, rather than the exposed granitic intrusion, was probably responsible for the formation of wolframite-quartz veins in this ore belt. In addition, combined with the metallogenic model described above, we put forward the possibility of finding disseminated mineralization at the deeper part of these deposits. 


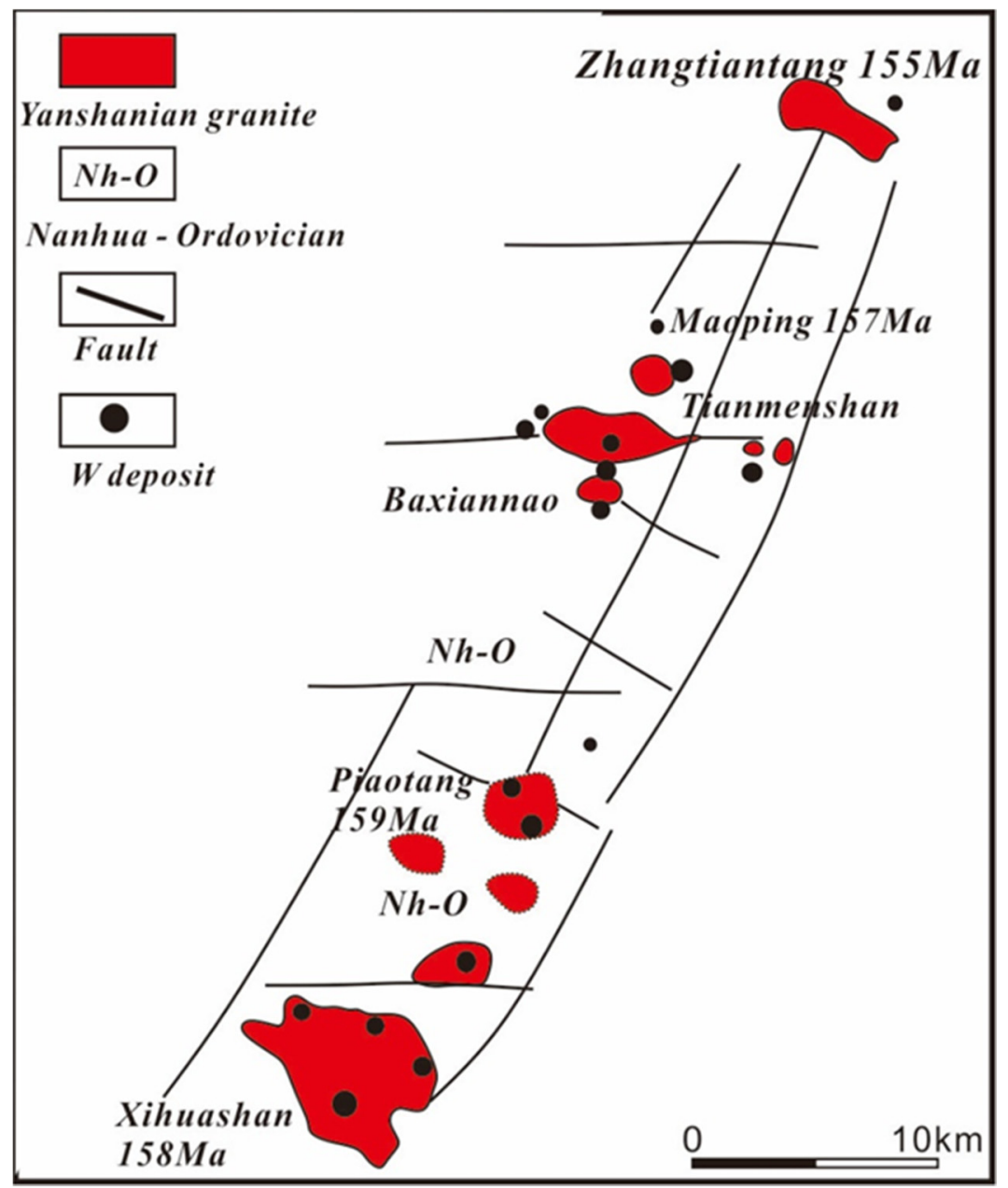

Figure 10. Simplified geological map of the Xihuashan-Zhangtiantang region of South China, showing roughly similar intervals (modified after [172]).

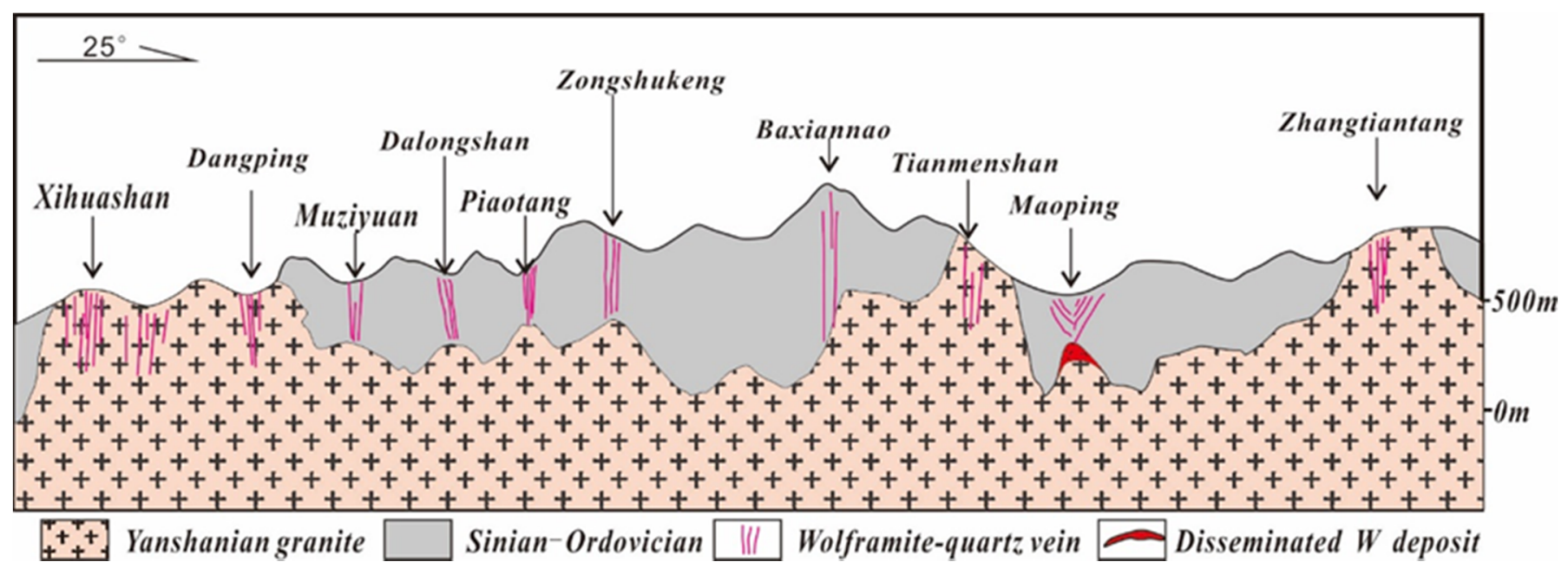

Figure 11. Geological profile of the Xihuashan-Zhangtiantang region of South China. Note that all wolframite-bearing quartz veins of economic value are located at similar specific horizontal elevations and intervals (modified after [172]). 

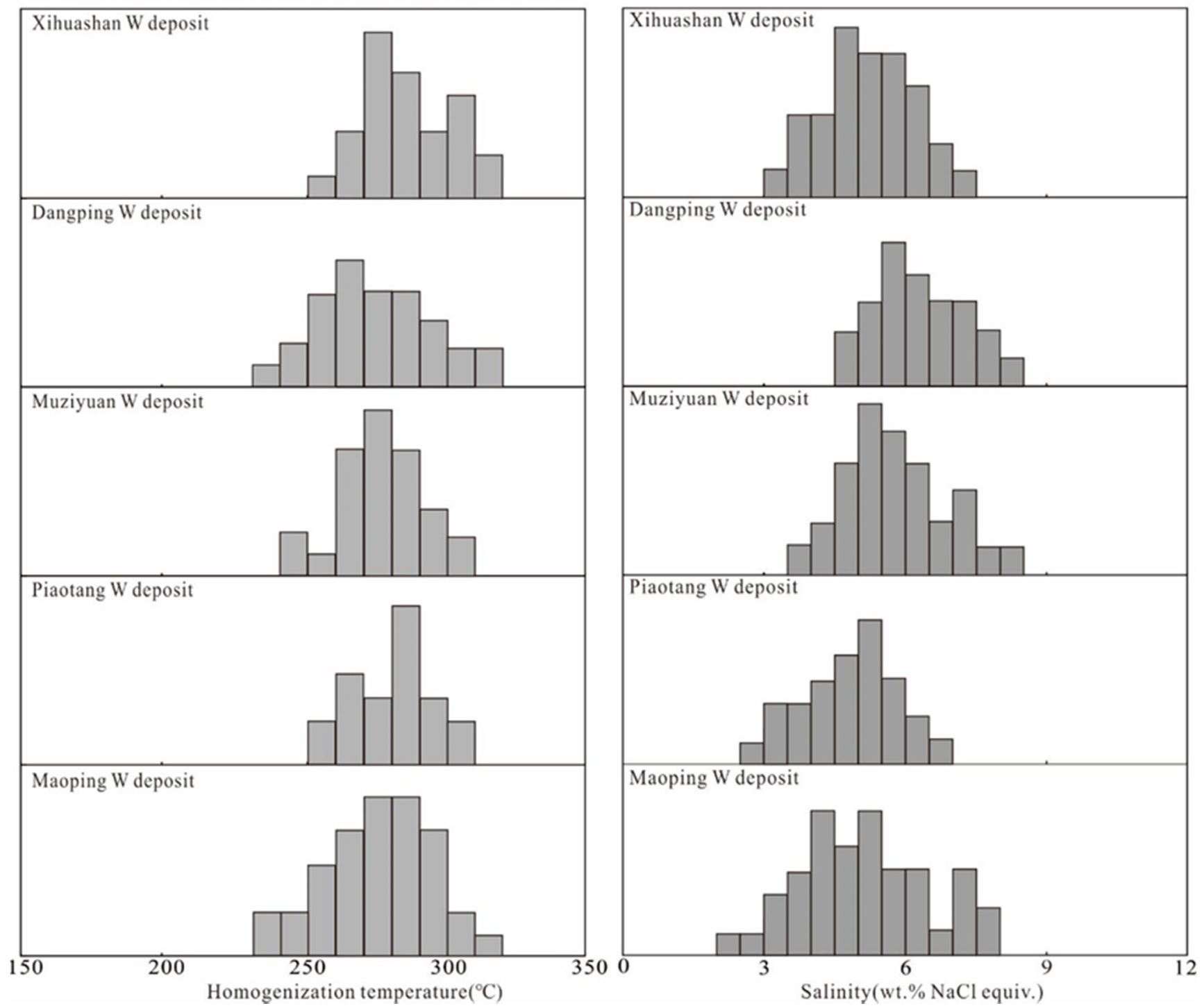

Figure 12. Histograms of homogenization temperatures $\left(T_{h}\right)$ and salinities for fluid inclusions from the different tungsten deposits in the Xihuashan-Zhangtiantang region.

\section{Evaluation of W Mineralization Potential}

The fluid and melt inclusions captured during the crystallization of host minerals are direct records of the fluids and melts involved in magmatic-hydrothermal systems. In the last two decades, the in situ LA-ICP-MS analysis of single-fluid and melt inclusions has provided many fundamental insights on the magmatic and hydrothermal processes leading to the formation of economic ore deposits (e.g., [13,15,17,85,176-180]). One of the most controversial issues in the formation of magmatic-hydrothermal ore deposits is whether the metallogenic potential of the system is correlated with the metal content of the emplaced magma and/or the exsolving fluids (e.g., [180,181]). For the past 20 years, systematic determination of the chemical compositions of fluids forming wolframite-quartz veins has been reported from a few locations including Mole Granite [85], Panasqueira [13], Zinnwald [15] and Yaogangxian [17]. Melt composition data of granite associated with wolframite-bearing W-Sn deposits are rare, but existing data have been obtained from a few locations such as Mole Granite and Ehrenfriedersdorf [85,182]. These data allow us to carry out a preliminary comparison of melt and fluid compositions in wolframite-quartz vein-type deposits, porphyry-type deposits and barren granitic systems. 


\subsection{W Contents in Barren and Mineralized Granite}

Distinguishing between fertile and barren granites has long been an important issue for understanding ore genesis and guiding mineral exploration. To clarify this issue, studies on W-related granites have paid much attention to whether they have unique geochemical characteristics. Previous petrogeochemical studies have found that high silicon, high potassium, W, F, Li and B anomalies, high $\mathrm{Rb} / \mathrm{Sr}$ ratios, and high mica concentrations are regarded as the marks of mineralized granites [57,183-188]. Comprehensive mineralogical studies also provide indexes to identify the mineralization potential of granite; for example, disseminated wolframite, scheelite and rutile are recognized as signs of strong mineralization potential $[8,46,167]$. The morphology and geochemistry of titanite in granite have also been used to evaluate W ore-forming potential [189]. Moreover, the studies of the zircon composition from granites in East Australia, Myanmar and the Nanling region reveal that most tungsten-associated granite is characterized by high temperatures, high tungsten concentrations, low oxygen fugacities and high degrees of evolution [184,190,191].

Although the whole-rock analysis and mineralogical indictors of granite have contributed to the accumulation of knowledge regarding the differences between mineralized and barren granite, the exact metal contents of the granite can only be obtained reliably from melt inclusion analysis. A series of pioneering works on melt inclusion from Momineralized and barren granite found no systematic differences in the initial Mo contents between barren and Mo mineralized systems, and no extraordinary Mo enrichment was involved in the magma of porphyry Mo deposits [192-194]. By comparing the volume of the magma chamber, the emplacement depth, and the magma temperature and viscosity, these studies suggest that the viscosity of mineralized magma is significantly lower than the average value of magma, indicating that magma with low viscosity may be conducive to mineral circulation and extraction, which is conducive to mineralization.

In addition, relatively rare melt inclusion data have been reported from granite associated with wolframite-quartz vein-type W (-Sn) deposits $[85,182]$. One reason for the shortage of such data is probably due to the difficulty in finding workable melt inclusions in W-associated granite that is usually fine-grained and altered. In the Nanling region of South China, typical crystallized melt inclusions in quartz phenocryst were found, in good preservation conditions, in many W-mineralized granite types such as Dajishan, Dangping, Piaotang and Muziyuan granite (Figure 13). These melt inclusions provide an excellent object of research to constrain the mineralization potential of these granites, and our LAICP-MS analysis on these melt inclusions is in progress. Here, a compilation of existing melt inclusion data from W (-Sn)-mineralized granite, Cu-dominated porphyry deposits, Mo-dominated porphyry deposits and barren granites is shown in Figure 14A. The data plot shows a clear positive correlation between the $W$ and $C$ s concentration, suggesting that $W$ are gradually enriched in the melt during fractional crystallization. In addition, the $\mathrm{W}$-mineralized granites are mostly evolved and yield the highest $\mathrm{W}$ concentrations in melts, indicating that high $\mathrm{W}$ content is probably a precondition for economic $\mathrm{W}$ mineralization. Notably, barren granite with similarly high fractionation degrees has $W$ contents that are lower than those of mineralized granite, possibly suggesting lower initial $\mathrm{W}$ contents in the protolith. 

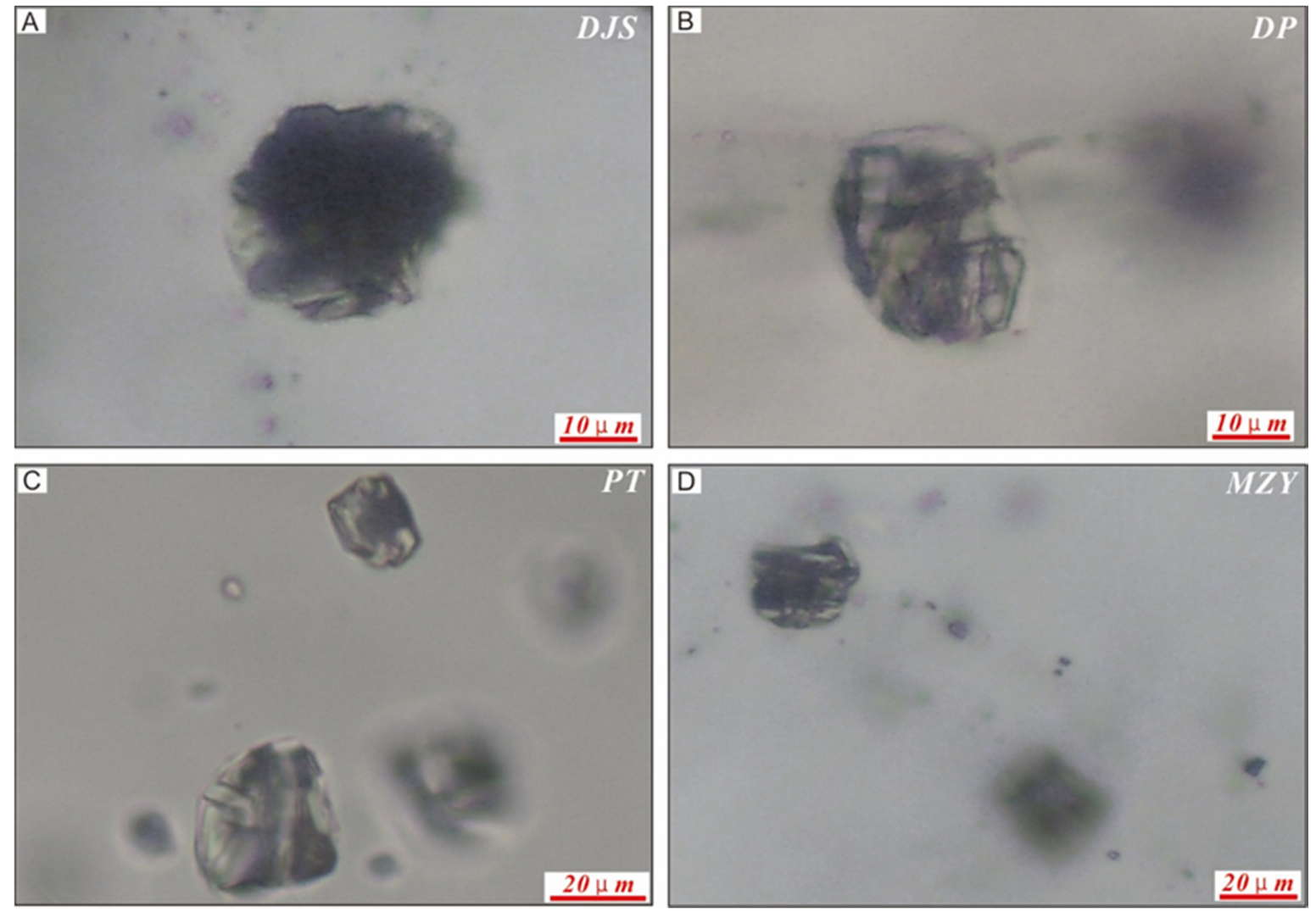

Figure 13. Melt inclusions trapped in quartz from granite. Typical melt inclusions from the Dajishan (A), Dangping (B), Piaotang (C) and Muziyuan (D) tungsten deposits in South China. Abbreviations: DJS-Dajishan; DP—Dangping; PT-Piaotang; MZY-Muziyuan.
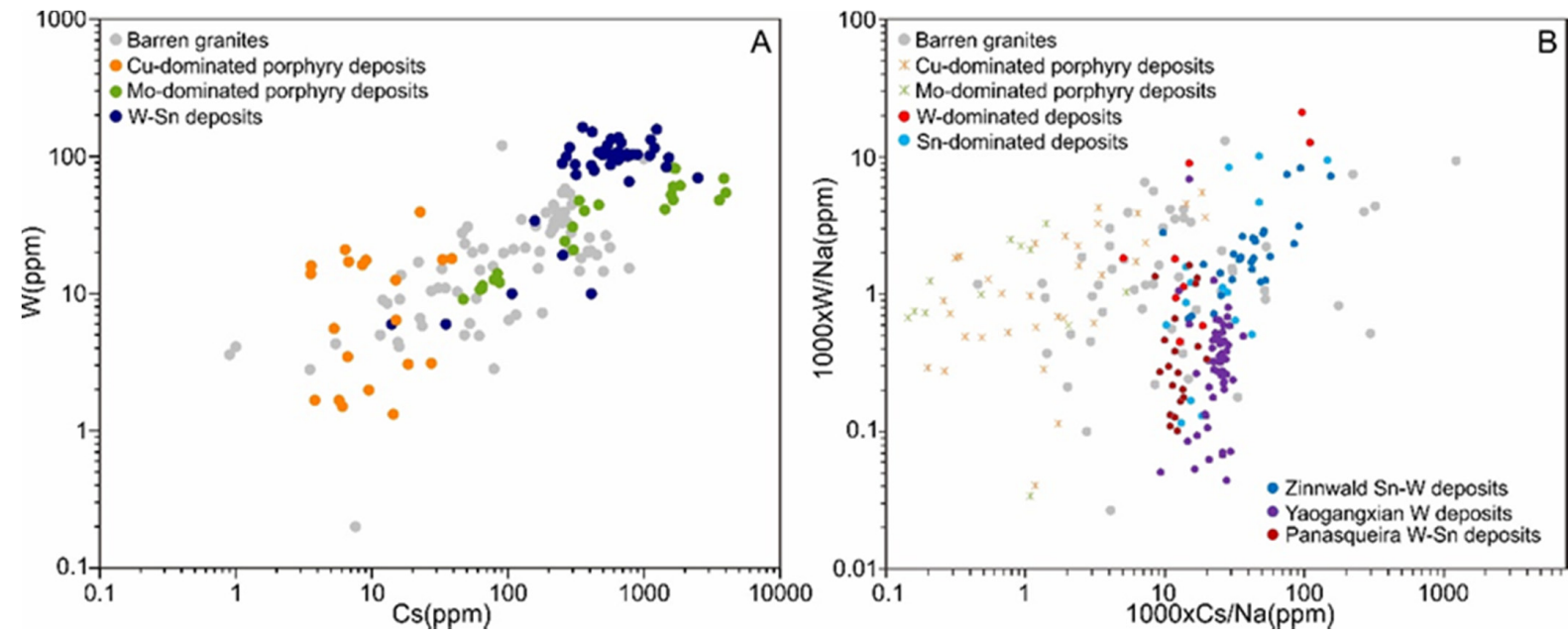

Figure 14. Diagrams of $\mathrm{W}$ vs. Cs concentration or concentration ratios of melt inclusions and fluid inclusions from mineralized, barren and porphyry systems. (A) W vs. Cs concentration diagram for melt inclusions of $\mathrm{W}$-associated and barren granite, also shown are porphyry $\mathrm{Cu}$ and porphyry Mo systems. Barren granites include: Rito del Medio, Huangshan and Mt. Malosa [182,195,196]; Cu-dominated porphyry deposits include: Elatsite [123]. Mo-dominated porphyry deposits include: Climax [193]. W-Sn deposits include: Mole Granite and Ehrenfriedersdorf [85,182]. (B) W/Na vs. Cs/Na ratios for initial fluids of mineralized and barren fluids, adopted from the database of [180]. Fluid compositions from three wolframite-bearing quartz vein-type deposits, i.e., Zinnwald, Yaogangxian and Panasqueira, are also plotted for comparison. Values are from [13], [15] and [17], respectively. 


\subsection{W Contents in Barren and Mineralized Hydrothermal Fluids}

Whether the mineralization potential is determined by the metal contents in the ore-forming fluids is a fundamental question for understanding the genesis of magmatichydrothermal deposits. Several previous studies have made remarkable progress on this issue. For example, based on LA-ICPMS analyses of single-fluid inclusions in barren and mineralized veins from the Schwarzwald mining district in SW Germany, Walter et al. (2019) [18] reported similar $\mathrm{Pb}-\mathrm{Zn}$ base metal and sulfur concentrations, which suggested that sulfide $(\mathrm{Pb}$ and $\mathrm{Zn})$ mineralization in these veins has no connect with metal solubility in fluids. On the contrary, the presence of a reducing phase during fluid mixing is responsible for metal precipitation. The systematic elemental analysis of individual fluid inclusions for Sn-dominated and W-dominated deposits in the Mole Granite ore district showed that the contents of $\mathrm{Sn}$ and $\mathrm{W}$ in the initial fluids were correlated positively with the corresponding metallogenic types, and it was speculated that the metallogenic potential of the deposit may be controlled by the metal content in the initial fluid [85]. Recently, Audetat et al. (2019) [180] compiled 169 groups of single-fluid inclusion composition data published in the last 20 years, and more comprehensively summarized the relationship between initial fluid metal composition and mineralization potential in granitic magmatic hydrothermal systems. However, the results only show a very weak positive correlation between the $\mathrm{W}$ concentration in the initial fluid and the $\mathrm{W}$ mineralizing potential of granitic magma.

In order to take a further step on this issue, fluid compositions from several recent studies on wolframite-quartz vein-type $\mathrm{W}$ deposits were compiled with the use of the database of mineralized and barren systems provided by [180]. The selection of the data was guided by the fact that they represent the best mineralization characteristics and the deposits are well known mineralogically and geochemically, i.e., the Panasqueira W-Sn deposit in Portugal [13], the Yaogangxian W deposit in South China [17] and the Zinnwald Sn-W deposit in Germany and the Czech Republic [15]. The plot is shown in Figure 14B, and it is worth noting that all element contents are normalized to $\mathrm{Na}$ to eliminate the salinity effect. If one looks at the initial $\mathrm{W}$ concentrations in both the $\mathrm{W}$ - and Sn-dominated mineralized systems, it is clear that W-Sn mineralized systems have the highest $\mathrm{W}$ concentrations as compared to most barren granite and porphyry $\mathrm{Cu}$ or Mo deposits. The positive correlation between W's abundance and the Cs contents suggests that $W$ behaves as an incompatible element during fractional crystallization [180]. Thus, the high $\mathrm{W}$ concentration in early-stage fluid may indicate high $\mathrm{W}$ mineralization potential and thereby act as a possible exploration tool. It is important to note that the fluid inclusion data obtained from Zinnwald, Panasqueira and Yaogangxian show relatively lower contents of $\mathrm{W}$ than those attributed to initial fluids. Given that these fluid inclusions are hosted mostly in vein quartz coexisting with wolframite, these data indeed suggest that quartz is generally formed later than wolframite and the fluids that deposited quartz are already W-depleted due to earlier wolframite deposition. It is expected that the early-stage fluids in these wolframite-quartz vein-type deposits have much higher $\mathrm{W}$ concentrations. It is also notable that much of the $\mathrm{W}$ concentrations from some barren and porphyry $\mathrm{Cu} / \mathrm{Mo}$ systems are equally high as those of mineralized systems, suggesting that $\mathrm{W}$ concentrations in early-stage fluid are not the sole determinant of mineralization potential. For porphyrytype deposits, the relatively higher oxygen fugacity of the magma can be a critical factor that acts against the deposition of W ore minerals in these systems [153]. Significantly, it is striking that all $\mathrm{W}$-mineralized fluids have $\mathrm{Cs} / \mathrm{Na}$ ratios in a very restricted interval, i.e., between 10 and $100\left(1000^{*} \mathrm{Cs} / \mathrm{Na}\right.$ in $\left.\mathrm{ppm}\right)$. This may imply a relatively fixed crystallization degree that is favorable for economic $\mathrm{W}$ mineralization.

In summary, positive correlations between both melt and fluid $\mathrm{W}$ concentrations and their mineralization potential are suggested by the compilation of the data. Melt and fluid inclusions can thus be used as potential tools for guiding $\mathrm{W}$ exploration. However, it is necessary to be cautious when fluid inclusion data from quartz veins are used for such evaluations because late-stage $\mathrm{W}$-depleted fluids may conceal the true mineralization 
potential of the ore-forming fluids. Thus, attention should be paid to the petrographically early-stage fluids or the highest $\mathrm{W}$ concentrations of the obtained fluid inclusion data.

\section{Conclusions and Prospects}

(1) Quartz in the wolframite-bearing quartz veins commonly undergoes multiple stages of precipitation, whereas wolframite is generally precipitated in narrow intervals. Conclusively, caution needs to be exercised when the fluid inclusions recorded in gangue minerals are used to represent ore-forming fluids.

(2) W-bearing hydrothermal fluids, rather than melts, have led to the large-scale precipitation of wolframite in quartz veins. Solid evidence for wolframite crystals that crystallize from melts or magmatic-hydrothermal transition fluids in nature is still lacking.

(3) Comprehensive statistics show that the occurrence of $\mathrm{CO}_{2}$ in wolframite-quartz vein tungsten deposits is random and wolframite-hosted fluid inclusions generally have low $\mathrm{CO}_{2}$ contents. Although the existence of $\mathrm{CO}_{2}$ can affect the $\mathrm{pH}$ of ore-forming fluids and, therefore, the stability of $\mathrm{W}$ complexes, its occurrence is not necessary for wolframite mineralization, especially in large-scale $\mathrm{W}$ deposits.

(4) Simple cooling, fluid boiling and fluid-rock interactions were found to be the principle mechanisms responsible for the precipitation of wolframite from hydrothermal fluid, whereas meteoric water mixing is less effective even though it frequently occurs in post-mineralization stages.

(5) The studies of wolframite-quartz vein-type tungsten deposits from different regions worldwide showed that the granitic magma is the main source for ore-forming fluids, and the involvement of metamorphic fluid, sedimentary fluid and mantle-derived fluid can occur locally.

(6) Wolframite-quartz veins are not necessarily genetically related to spatially associated granites. High-precision geochronology and fluid source evaluation can provide key evidence for verifying their genetic link and, in turn, can guide mineral exploration and targeting.

(7) Based on the data compilation of melt and fluid inclusions in W-mineralized and barren systems, it is suggested that the metallogenic potential of granite-related magmatic-hydrothermal systems is determined to a great extent by the $\mathrm{W}$ contents in granite melts and early-stage exsolving fluids, which, in turn, can be potential tools for $\mathrm{W}$ exploration.

Author Contributions: Conceptualization, P.N. and J.-Y.P.; methodology, W.-S.L.; software, W.-S.L. and J.-M.C.; validation, P.N. and J.-Y.P.; formal analysis, W.-S.L. and Y.G.; investigation, W.-S.L. and K.-H.Z.; resources, P.N.; data curation, J.-M.C. and Y.G.; writing-original draft preparation, W.-S.L.; writing-review and editing, J.-Y.P. and P.N.; visualization, W.-S.L. and Y.G.; supervision, P.N. All authors have read and agreed to the published version of the manuscript.

Funding: This research was funded by a Key Project of the National Natural Science Foundation of China (Grant No. 41830426), a Key Support Project of Major Research Plan of the National Natural Science Foundation of China (Grant No. 92062220), a Fundamental Research Funds for the Central Universities (Grant No. 020614380117), a National Key R\&D Program of China (Grant No. 2018YFA0702700) and two Youth Funds of National Natural Science Foundation of China (Grant No. 42002074) and Jiangsu Province (BK20200325).

Data Availability Statement: Data sharing not applicable.

Acknowledgments: Zhe Chi is especially thanked for collecting melt inclusion data from the literature.

Conflicts of Interest: The authors declare no conflict of interest. 


\section{References}

1. Mao, J.W.; Xie, G.Q.; Guo, C.L.; Chen, Y.C. Large-scale tungsten-tin mineralization in the Nanling region, South China: Metallogenic ages and corresponding geodynamic processes. Acta Petrol. Sin. 2007, 23, 2329-2338. (In Chinese with English Abstract).

2. Wang, X.D.; Ni, P.; Jiang, S.Y.; Zhao, K.D.; Wang, T.G. Origin of ore-forming fluid in the Piaotang tungsten deposit in Jiangxi Province: Evidence from Helium and argon isotopes. Chinese Sci. Bull. 2009, 54, 3338-3344. (In Chinese with English Abstract). [CrossRef]

3. Hu, R.Z.; Zhou, M.F. Multiple Mesozoic mineralization events in South China-an introduction to the thematic issue. Miner Depos. 2012, 47, 579-588. [CrossRef]

4. Ni, P.; Wang, X.D.; Wang, G.G.; Huang, J.B.; Pan, J.Y.; Wang, T.G. An infrared microthermometric study of fluid inclusions in coexisting quartz and wolframite from Late Mesozoic tungsten deposits in the Gannan metallogenic belt, South China. Ore Geol. Rev. 2015, 65, 1062-1077. [CrossRef]

5. Yuan, S.D.; Williams-Jones, A.E.; Mao, J.W.; Zhao, P.L.; Yan, C.; Zhang, D.L. The origin of the Zhangjialong tungsten deposit, South China: Implications for W-Sn mineralization in large granite batholiths. Econ. Geol. 2018, 113, 1193-1208. [CrossRef]

6. $\quad$ Li, W.S.; Ni, P.; Pan, J.Y.; Wang, G.G.; Chen, L.L.; Yang, Y.L.; Ding, J.Y. Fluid inclusion characteristics as an indicator for tungsten mineralization in the Mesozoic Yaogangxian tungsten deposit, central Nanling district, South China. J. Geochem. Explor. 2018, 192, 1-17. [CrossRef]

7. Ni, P.; Li, W.S.; Pan, J.Y. Ore-forming Fluid and Metallogenic Mechanism of Wolframite-Quartz Vein-type Tungsten Deposits in South China. Acta Geol. Sin. -Engl. Ed. 2020, 94, 1774-1796. [CrossRef]

8. Carocci, E.; Marignac, C.; Cathelineau, M.; Truche, L.; Poujol, M.; Boiron, M.C.; Pinto, F. Incipient Wolframite Deposition at Panasqueira (Portugal): W-Rich Rutile and Tourmaline Compositions as Proxies for the Early Fluid Composition. Econ. Geol. 2020, 116, 123-146. [CrossRef]

9. Li, J.J.; Cao, S.A.; Yilmaz, E.; Liu, Y.P. Compressive fatigue behavior and failure evolution of additive fiber-reinforced cemented tailings composites. Int. J. Miner. Metall. Mater. 2022, 29, 345-355. [CrossRef]

10. Lynch, J.V. Hydrothermal alteration, veining, and fluid-inclusion characteristics of the Kalzas wolframite deposit, Yukon. Can. J. Earth Sci. 1989, 26, 2106-2115. [CrossRef]

11. Hulsbosch, N.; Boiron, M.C.; Dewaele, S.; Muchez, P. Fluid fractionation of tungsten during granite-pegmatite differentiation and the metal source of peribatholitic W quartz veins: Evidence from the Karagwe-Ankole Belt (Rwanda). Geochim. Cosmochim. Acta 2016, 175, 299-318. [CrossRef]

12. Dewaele, S.; De Clercq, F.; Hulsbosch, N.; Piessens, K.; Boyce, A.; Burgess, R.; Muchez, P. Genesis of the vein-type tungsten mineralization at Nyakabingo (Rwanda) in the Karagwe-Ankole belt, Central Africa. Miner. Depos. 2016, 51, 283-307. [CrossRef]

13. Lecumberri-Sanchez, P.; Vieira, R.; Heinrich, C.A.; Pinto, F.; Walle, M. Fluid-rock interaction is decisive for the formation of tungsten deposits. Geology 2017, 45, 579-582. [CrossRef]

14. Breiter, K.; Durišová, J.; Hrstka, T.; Korbelová, Z.; Hložková Vaňková, M.; Vašinová Galiová, M.; Kanický, V.; Rambousek, P.; Knésl, I.; Dobeš, P.; et al. Assessment of magmatic vs. metasomatic processes in rare-metal granites: A case study of the Cínovec/Zinnwald Sn-W-Li deposit, Central Europe. Lithos 2017, 292, 198-217. [CrossRef]

15. Korges, M.; Weis, P.; Luders, V.; Laurent, O. Depressurization and boiling of a single magmatic fluid as a mechanism for tin-tungsten deposit formation. Geology 2018, 46, 75-78. [CrossRef]

16. Mao, J.W.; Wu, S.H.; Song, S.W.; Dan, P.; Xie, G.Q.; Sun, Q.W.; Liu, P.; Wang, X.G.; Yu, Z.Z.; Chen, X.Y.; et al. The world-class Jiangnan tungsten belt: Geological characteristics, metallogeny, and ore deposit model. Sci. Bull. 2020, 65, 3746-3762. (In Chinese) [CrossRef]

17. Pan, J.Y.; Ni, P.; Wang, R.C. Comparison of fluid processes in coexisting wolframite and quartz from a giant vein-type tungsten deposit, South China: Insights from detailed petrography and LA-ICP-MS analysis of fluid inclusions. Am. Mineral. 2019, 104, 1092-1116. [CrossRef]

18. Walter, B.F.; Kortenbruck, P.; Scharrer, M.; Zeitvogel, C.; Wälle, M.; Mertz-Kraus, R.; Markl, G. Chemical evolution of ore-forming brines-Basement leaching, metal provenance, and the redox link between barren and ore-bearing hydrothermal veins. A case study from the Schwarzwald mining district in SW-Germany. Chem. Geol. 2019, 506, 126-148. [CrossRef]

19. Monnier, L.; Salvi, S.; Jourdan, V.; Sall, S.; Bailly, L.; Melleton, J.; Béziat, D. Contrasting fluid behavior during two styles of greisen alteration leading to distinct wolframite mineralizations: The Echassières district (Massif Central, France). Ore Geol. Rev. 2020, 124, 103648. [CrossRef]

20. Launay, G.; Sizaret, S.; Lach, P.; Melleton, J.; Gloaguen, É.; Poujol, M. Genetic relationship between greisenization and Sn-W mineralizations in vein and greisen deposits: Insights from the Panasqueira deposit (Portugal). Bsgf-Earth Sci. Bull. 2021, 192, 2. [CrossRef]

21. Li, W.S.; Ni, P.; Pan, J.Y.; Fan, M.S.; Chen, L.L.; Zhang, D.; Wu, X.W.; Gao, Y. Constraints on the timing and genetic link of scheeliteand wolframite-bearing quartz veins in the Chuankou W ore field, South China. Ore Geol. Rev. 2021, 133, 104122. [CrossRef]

22. Campbell, A.R.; Panter, K.S. Comparison of fluid inclusions in coexisting (cogenetic?) wolframite, cassiterite, and quartz from St. Michael's Mount and Cligga Head, Cornwall, England. Geochim. Cosmochim. Acta 1990, 54, 673-681. [CrossRef] 
23. Chen, L.L.; Ni, P.; Li, W.S.; Ding, J.Y.; Pan, J.Y.; Wang, G.G.; Yang, Y.L. The link between fluid evolution and vertical zonation at the Maoping tungsten deposit, Southern Jiangxi, China: Fluid inclusion and stable isotope evidence. J. Geochem. Explor. 2018, 192, 18-32. [CrossRef]

24. Irving, J.D. Some recently exploited deposits of wolframite in the Black Hills of South Dakota. AIME Trans. 1901, $31,683-695$.

25. Lindgren, W. Some gold and tungsten deposits of Boulder County, Colorado. Econ. Geol. 1907, 2, 453-463. [CrossRef]

26. Hess, F.L. Tin, tungsten, and tantalum deposits of South Dakota. Contrib. Econ. Geol. 1908, 131-168.

27. Hsu, K.C. Tungsten deposits of southern Kiangsi, China. Econ. Geol. 1943, 38, 431-474. [CrossRef]

28. Bodnar, R.J.; Reynolds, T.J.; Kuehn, C.A. Fluid inclusion systematics in epithermal systems. Rev. Econ. Geol. 1985, 2, 73-97.

29. Hedenquist, J.W.; Arribas, A.; Reynolds, T.J. Evolution of an intrusion-centered hydrothermal system: Far Southeast-Lepanto porphyry and epithermal Cu-Au deposits, Philippines. Econ. Geol. 1998, 93, 373-404. [CrossRef]

30. Heinrich, C.A.; Gunther, D.; Audetat, A.; Ulrich, T.; Frischknecht, R. Metal fractionation between magmatic brine and vapor, determined by microanalysis of fluid inclusions. Geology 1999, 27, 755-758. [CrossRef]

31. Wilkinson, J.J. Fluid inclusions in hydrothermal ore deposits. Lithos 2001, 55, 229-272. [CrossRef]

32. Kelly, W.C.; Rye, R.O. Geologic, fluid inclusion and stable isotope studies of the tin tungsten deposits of Panasqueira, Portugal. Econ. Geol. 1979, 74, 1721-1822. [CrossRef]

33. Landis, G.P.; Rye, R.O. Geologic, fluid inclusion, and stable isotope studies of the Pasto Buena tungsten-base metal ore deposit, northern Peru. Econ. Geol. 1974, 69, 1025-1059. [CrossRef]

34. Enjoji, M. Present and future researches of fluid inclusion from vein-type deposits. Min. Geol. Spec. Issue 1976, 85-100.

35. So, C.S.; Yun, S. Origin and evolution of W-Mo-producing fluids in a granitic hydrothermal system: Geochemical studies of quartz vein deposits around the Susan granite, Hwanggangri District, Republic of Korea. Econ. Geol. 1994, 89, 246-267. [CrossRef]

36. Wang, X.D.; Ni, P.; Yuan, S.D.; Wu, S.H. Characteristics of fluid inclusions of the Muziyuan tungsten deposit in Southern Jiangxi Province and their geological implications. Geol. China 2012, 39, 1790-1797. (In Chinese with English Abstract).

37. Jiang, H.; Jiang, S.Y.; Li, W.Q.; Peng, N.J.; Zhao, K.D. Fluid inclusion and isotopic (C, H, O, S and Pb) constraints on the origin of late Mesozoic vein-type W mineralization in northern Guangdong, South China. Ore Geol. Rev. 2019, 112, 103007. [CrossRef]

38. Huang, H.L.; Li, F.; Tan, J.; Zhang, C.H. Discovery and Preliminary Investigation of Melt inclusions in Wolframite of Xihuashan Deposit, Southern Jiangxi Province. Geol. Miner. Resour. S. China 2012, 28, 181-183. (In Chinese with English Abstract).

39. Che, X.D.; Linnen, R.L.; Wang, R.C.; Aseri, A.; Thibault, Y. Tungsten solubility in evolved granitic melts: An evaluation of magmatic wolframite. Geochim. Cosmochim. Acta 2013, 106, 84-98. [CrossRef]

40. Zhang, S.M.; Chen, Z.H.; Shi, G.H.; Li, L.X.; Qu, W.J.; Li, C. Re-Os isotopic dating of molybdenite from Dajishan tungsten deposit in Jiangxi Province. Miner. Depos. 2011, 30, 1113-1121. (In Chinese with English Abstract).

41. Feng, C.Y.; Wang, S.; Zeng, Z.L.; Zhang, D.Q.; Li, D.X.; She, H.Q. Fluid inclusion and chronology studies of Baxiannao mineralized fractured zone-type tungsten polymetallic deposit, southern Jiangxi Province, China. Acta Petrol. Sin. 2012, 28, 52-64. (In Chinese with English Abstract).

42. Liu, S.B.; Chen, Y.C.; Fan, S.X.; Xu, J.X.; Qu, W.J.; Ying, L.J. The second ore-prospecting space in the eastern and central parts of the Nanling metallogenic belt:evidence from isotopic chronology. Geol. China 2010, 37, 1034-1049. (In Chinese with English Abstract)

43. Li, L.X.; Chen, Z.H.; Shi, G.H.; Zhang, S.M.; Qu, W.J.; Ying, L.J.; Qin, Y.; Ding, Q. Metallogenic epoch and geological characteristics of the Kuimeishan tungsten deposit, Jiangxi province. Rock Miner. Anal. 2014, 33, 287-295. (In Chinese with English Abstract).

44. Feng, C.Y.; Huang, F.; Zeng, Z.L.; Qu, W.J.; Ding, M. Isotopic chronology of Julongnao granite and Hongshuizhai greisens-type tungten deposit in South Jiangxi province. J. Jilin Univ. (Earth Sci.) 2011, 41, 111-121. (In Chinese with English Abstract).

45. Chen, L.L.; Ni, P.; Dai, B.Z.; Li, W.S.; Chi, Z.; Pan, J.Y. The Genetic Association between Quartz Vein- and Greisen-Type Mineralization at the Maoping W-Sn Deposit, Southern Jiangxi, China: Insights from Zircon and Cassiterite U-Pb Ages and Cassiterite Trace Element Composition. Minerals 2019, 7, 411. [CrossRef]

46. Zhang, W.L.; Hua, R.M.; Wang, R.C.; Li, H.M.; Qu, W.J.; Ji, J.Q. New Dating of the Piaotang Granite and Related Tungsten Mineralization in Southern Jiangxi. Acta Petrol. Sin. 2009, 83, 659-670. (In Chinese with English Abstract). [CrossRef]

47. Li, G.L.; Hua, R.M.; Zhou, L.Q.; Tang, A. Ar-Ar Age of Muscovite in the Xushan W-Cu Deposit, Central Jiangxi, and its Geological Significances. Acta Geol. Sin.-Engl. Ed. 2014, 88, 12. [CrossRef]

48. Fang, G.C.; Chen, Y.C.; Chen, Z.H.; Zeng, Z.L.; Zhang, Y.Z.; Tong, Q.Q.; Sun, J.; Huang, H.X.; Guo, N.X. Zircon U-Pb and Molybdenite Re-Os Geochronology of the Pangushan Tungsten Deposit in South Jiangxi Province and Its Significance. Acta Geol. Sin. 2014, 145, 76-84. (In Chinese with English Abstract).

49. Zhang, R.Q.; Lu, J.J.; Lehmann, B.; Li, C.Y.; Li, G.L.; Zhang, L.P.; Guo, J.; Sun, W.D. Combined zircon and cassiterite U-Pb dating of the Piaotang granite-related tungsten-tin deposit, southern Jiangxi tungsten district, China. Ore Geol. Rev. 2017, 82, 268-284. [CrossRef]

50. Guo, C.L.; Mao, J.W.; Bierlein, F.; Chen, Z.H.; Chen, Y.C.; Li, C.B.; Zeng, Z.L. SHRIMP U-Pb (zircon), Ar-Ar (muscovite) and Re-Os (molybdenite) isotopic dating of the Taoxikeng tungsten deposit, South China Block. Ore Geol. Rev. 2011, 43, 26-39. [CrossRef]

51. Feng, C.Y.; Zhao, Z.; Qu, W.J.; Zeng, Z.L. Temporal consistency between granite evolution and tungsten mineralization in Huamei'ao, southern Jiangxi Province, China: Evidence from precise zircon $\mathrm{U}-\mathrm{Pb}$, molybdenite $\mathrm{Re}-\mathrm{Os}$, and muscovite $40 \mathrm{Ar}-39 \mathrm{Ar}$ isotope geochronology. Ore Geol. Rev. 2015, 65, 1005-1020. [CrossRef]

52. Zhang, W.L.; Hua, R.M.; Wang, R.C.; Xie, L.; Che, X.D. SHRIMP Zircon U-Pb dating of ore-forming granites in Tieshanlong tungsten deposit, Southern Jiangxi province. Miner. Depos. 2012, 31. (In Chinese with English Abstract). [CrossRef] 
53. Liu, Q.; Ye, H.S.; Xie, G.Q.; Yang, G.Q.; Zhang, W. Re-Os age of molybdenite from Hukeng tungsten deposit in Wugongshan area, Jiangxi province and its geological significance. Acta Petrol. Sin. 2008, 82, 1572-1579. (In Chinese with English Abstract).

54. Hu, R.Z.; Wei, W.F.; Bi, X.W.; Peng, J.T.; Qi, Y.Q.; Wu, L.Y.; Chen, Y.W. Molybdenite Re-Os and muscovite $\mathrm{Ar}^{-40} / \mathrm{Ar}^{-39}$ dating of the Xihuashan tungsten deposit, central Nanling district, South China. Lithos 2012, 150, 111-118. [CrossRef]

55. Wang, Y.L.; Pei, R.F.; Li, J.W.; Wang, H.L.; Liu, X.F. Geochemical characteristics and rhenium-osmium isotopic dating of granites from Jiangjunzhai tungsten deposit, Southeastern Hunan. Acta Petrol. Sin. 2009, 28, 274-278. (In Chinese with English Abstract).

56. Fu, J.M.; Li, H.Q.; Qu, W.J.; Yang, X.J.; Wei, J.Q.; Liu, G.Q.; Ma, L.Y. Re-Os isotope dating of the Da'ao tungsten-tin deposit in the Jiuyi Mountains, southern Hunan Province. Geol. China 2007, 34, 651-656. (In Chinese with English Abstract).

57. Li, W.S.; Ni, P.; Wang, G.G.; Yang, Y.L.; Pan, J.Y.; Wang, X.L.; Chen, L.L.; Fan, M.S. A possible linkage between highly fractionated granitoids and associated W-mineralization in the Mesozoic Yaogangxian granitic intrusion, Nanling region, South China. $J$. Asian Earth Sci. 2020, 193, 104314. [CrossRef]

58. Yang, Q.; Xuan, P.; Zhang, X.; Zhou, W.; Qu, H. Immiscibility and mineralization of Dawangshan tungsten polymetallic deposit, central Jiangxi Province. Chin. J. Geol. 2018, 52, 1282-1296. (In Chinese with English Abstract).

59. Yan, C.; Zhao, H.J.; Zhao, P.L.; Yuan, S.D. Muscovite Ar-Ar isotopic dating of Zhenkou quartz vein type wolframite deposit in southern Hunan Province and its significance for regional exploration. Miner. Depos. 2019, 38, 1147-1158. (In Chinese with English Abstract).

60. Cao, J.Y.; Wu, Q.H.; Yang, X.Y.; Kong, H.; Li, H.; Xi, X.S.; Huang, Q.F.; Liu, B. Geochronology and Genesis of the Xitian W-Sn Polymetallic Deposit in Eastern Hunan Province, South China: Evidence from Zircon U-Pb and Muscovite Ar-Ar Dating, Petrochemistry, and Wolframite Sr-Nd-Pb Isotopes. Minerals 2018, 8, 111. [CrossRef]

61. Zhang, R.Q.; Lu, J.J.; Wang, R.C.; Yang, P.; Zhu, J.C.; Yao, Y.; Gao, J.F.; Li, C.; Lei, Z.H.; Zhang, W.L.; et al. Constraints of in situ zircon and cassiterite U-Pb, molybdenite Re-Os and muscovite Ar-40-Ar-39 ages on multiple generations of granitic magmatism and related W-Sn mineralization in the Wangxianling area, Nanling Range, South China. Ore Geol. Rev. 2015, 65, 1021-1042. [CrossRef]

62. Zhao, Z.; Zhao, W.W.; Lu, L.; Wang, H.Y. Constraints of multiple dating of the Qingshan tungsten deposit on the Triassic W(-Sn) mineralization in the Nanling region, South China. Ore Geol. Rev. 2018. 94, 46-57. [CrossRef]

63. Liu, S.B.; Wang, D.H.; Chen, Y.C.; Li, J.K.; Ying, L.J.; Xu, J.X.; Zeng, Z.L. ${ }^{40} \mathrm{Ar} /{ }^{39} \mathrm{Ar}$ Ages of Muscovite from Different Types Tungsten-Bearing Quartz Veins in the Chong-Yu-You Concentrated Mineral Area in Gannan Region and Its Geological Significance. Acta Petrol. Sin. 2008, 82, 932-940. (In Chinese with English Abstract). [CrossRef]

64. Zou, X.W.; Cui, S.; Qu, W.J.; Bai, Y.S.; Chen, X.Q. Re-Os isotope dating of the Liguifu tungsten-tin polymetallic deposit in Dupangling area, Guangxi. Geol. China 2009, 36, 837-844. (In Chinese with English Abstract). [CrossRef]

65. Peng, N.L.; Wang, X.H.; Yang, J.; Chen, D.; Luo, L.; Luo, P.; Liu, T.Y. Re-Os dating of molybdenite from Sanjiaotan tungsten deposit in Chuankou area, Hunan Province, and its geological implications. Miner. Depos. 2017, 36, 1402-1414.

66. Wu, J.; Liang, H.Y.; Huang, W.T.; Wang, C.L.; Sun, W.D.; Sun, Y.L.; Li, J.; Mo, J.H.; Wang, X.Z. Re-Os dating of molybdenite from Sanjiaotan tungsten deposit in Chuankou area, Hunan Province, and its geological implications. Chin. Sci. Bull. 2012, 57, 1126-1136. (In Chinese with English Abstract).

67. Qi, H.W.; Hu, R.Z.; Wang, X.F.; Qu, W.J.; Bi, X.W.; Peng, J.T. Molybdenite Re-Os and muscovite ${ }^{40} \mathrm{Ar} /{ }^{39} \mathrm{Ar}$ dating of quartz vein-type W-Sn polymetallic deposits in Northern Guangdong, South China. Miner. Depos. 2012, 47, 607-622. [CrossRef]

68. Jiang, H.; Jiang, S.Y.; Li, W.Q.; Zhao, K.D.; Peng, N.J. Highly fractionated Jurassic I-type granites and related tungsten mineralization in the Shirenzhang deposit, northern Guangdong, South China: Evidence from cassiterite and zircon U-Pb ages, geochemistry and Sr-Nd-Pb-Hf isotopes. Lithos 2018, 312-313, 186-203. [CrossRef]

69. Wang, D.H.; Tang, J.X.; Ying, L.J.; Chen, Z.H.; Xu, J.X.; Zhang, J.J.; Li, S.R.; Zeng, Z.L. Application of "five levels + basement" model for prospecting deposits into depth. J. Jilin Univ. (Earth Sci. Ed.) 2010, 40, 733-738. (In Chinese with English Abstract).

70. Fu, J.M.; Li, F.Q.; Qu, W.J.; Ma, L.Y.; Yang, X.J.; Wei, J.Q.; Liu, G.Q. Determination of mineralization epoch of quartz-vein type tungsten deposit in Shixing region, Northern Guangdong and its geological significance. Geotecton. et Metallog. 2008, 32 , 57-62. (In Chinese with English Abstract).

71. Li, J.M.; Li, Y.M.; Lou, F.S.; Hu, Z.H.; Zhong, Q.H.; Xie, M.M.; Tang, F.L.; Sha, M.; Yang, X.H. A “Five-floor" style quartz vein wolframite deposit in Northern Jiangxi province: The discovery of the Dongping wolframite deposit and its geological significance. Acta Petrol. Sin. 2016, 37, 379-384. (In Chinese with English Abstract).

72. Yu, C.F.; Zhao, H.J.; Chen, M.H.; Luo, D.L.; Wang, Z.H. Geochemical features and petrogenesis of the Dajinshan granites in west Guangdong Province. Geol. China 2012, 39, 1670-1689. (In Chinese with English Abstract).

73. Xiao, R.; Li, X.F.; Feng, Z.H.; Yang, F.; Song, C.A. ${ }^{40} \mathrm{Ar} /{ }^{39} \mathrm{Ar}$ dating of muscovite from tungsten-quartz veins in Shanhu tungsten-tin deposit and its geological significance. Miner. Depos. 2011, 30, 488-496. (In Chinese with English Abstract).

74. Xiong, Y.Q.; Shao, Y.J.; Cheng, Y.B.; Jiang, S.Y. Discrete Jurassic and Cretaceous Mineralization Events at the Xiangdong W(-Sn) Deposit, Nanling Range, South China. Econ. Geol. 2020, 115, 385-413. [CrossRef]

75. Machadoa, N.; Lindenmayer, Z.; Krogh, T.E.; Lindenmayerb, D. U-Pb geochronology of Archean magmatism and basement reactivation in the Carajás area, Amazon shield, Brazil. Precam. Res. 1991, 49, 329-354. [CrossRef]

76. Kamilli, R.J.; Cole, J.C.; Elliott, J.E.; Criss, R.E. Geology and genesis of the Baid Al Jiamlah tungsten deposit, Kingdom of Saudi-Arabia. Econ. Geol. 1993, 88, 1743-1767. [CrossRef] 
77. Schaltegger, U.; Pettke, T.; Audetat, A.; Reusser, E.; Heinrich, C.A. Magmatic-to-hydrothermal crystallization in the W-Sn mineralized Mole Granite (NSW, Australia)-Part I: Crystallization of zircon and REE-phosphates over three million years-a geochemical and U-Pb geochronological study. Chem. Geol. 2005, 220, 215-235. [CrossRef]

78. Pettke, T.; Audétat, A.; Schaltegger, U.; Heinrich, C.A. Magmatic-to-hydrothermal crystallization in the W-Sn mineralized Mole Granite (NSW, Australia): Part II: Evolving zircon and thorite trace element chemistry. Chem. Geol. 2005, 220, 191-213. [CrossRef]

79. Harlaux, M.; Mercadier, J.; Bonzi, W.M.E.; Kremer, V.; Marignac, C.; Cuney, M. Geochemical Signature of Magmatic-Hydrothermal Fluids Exsolved from the Beauvoir Rare-Metal Granite (Massif Central, France): Insights from LA-ICPMS Analysis of Primary Fluid Inclusions. GEOFLUIDS 2017, 1-25. [CrossRef]

80. Harlaux, M.; Mercadier, J.; Marignac, C.; Peiffert, C.; Cloquet, C.; Cuney, M. Tracing metal sources in peribatholitic hydrothermal W deposits based on the chemical composition of wolframite: The example of the Variscan French Massif Central. Chem. Geol. 2018, 479, 58-85. [CrossRef]

81. Bobos, I.; Gonçalves, A.M.; Lima, L.; Noronha, F.; Sudo, M. Micas ${ }^{40} \mathrm{Ar} /{ }^{39} \mathrm{Ar}$ dating of hydrothermal events related with the post-orogenic $\mathrm{W}( \pm \mathrm{Sn}),(\mathrm{Cu}, \mathrm{Mo})$ mineralization from Borralha, Northern Portugal. In Proceedings of the 15th SGA Biennial Meeting 2019-Life with Ore Deposits on Earth, Glasgow, UK, 27-30 August 2019; Volume 1, pp. 353-356.

82. Romer, R.L.; Kroner, U. Phanerozoic tin and tungsten mineralization-Tectonic controls on the distribution of enriched protoliths and heat sources for crustal melting. Gondwana Res. 2016, 31, 60-95. [CrossRef]

83. Mao, J.W.; Ouyang, H.G.; Song, S.W.; Santosh, M.; Yuan, S.D.; Zhou, Z.H.; Zheng, W.; Liu, H.; Liu, P.; Cheng, Y.B.; et al. Geology and Metallogeny of Tungsten and Tin Deposits in China. SEG Spec. Publ. 2019, 22, 411-482.

84. Mlynarczyk, M.S.J.; Williams-Jones, A.E. The role of collisional tectonics in the metallogeny of the Central Andean tin belt. Earth Planet. Sc. Lett. 2005, 240, 656-667. [CrossRef]

85. Audétat, A.; Gunther, D.; Heinrich, C.A. Magmatic-hydrothermal evolution in a fractionating granite: A microchemical study of the Sn-W-F mineralized Mole Granite (Australia). Geochim. Cosmochim. Acta 2000, 64, 3373-3393. [CrossRef]

86. Ni, P.; Wang, G.G.; Li, W.S.; Chi, Z.; Li, S.N.; Gao, Y. A review of the Yanshanian ore-related felsic magmatism and tectonic settings in the Nanling W-Sn and Wuyi Au-Cu metallogenic belts, Cathaysia Block, South China. Ore Geol. Rev. 2021, 133, 104088. [CrossRef]

87. Li, W.S. Genesis and Metallogenic Setting of the Chuankou and Yaogangxian Tungsten Deposits, Southeast Hunan Province. Ph.D. Thesis, Nanjing University, Nanjing, China, August 2021.

88. Li, W.-S.; Ni, P.; Pan, J.-Y.; De Vivo, B.; Albanese, S.; Fan, M.-S.; Gao, Y.; Zhang, D.-X.; Chi, Z. Co-genetic formation of scheel-iteand wolframite-bearing quartz veins in the Chuankou $W$ deposit, South China: Evidence from individual fluid inclusion and wall-rock alteration analysis. Ore Geol. Rev. 2020, 142, 104723. [CrossRef]

89. Li, H.; Cao, J.Y.; Algeo, T.J.; Jiang, W.C.; Liu, B.; Wu, Q.H. Zircons reveal multi-stage genesis of the Xiangdong (Dengfuxian) tungsten deposit, South China. Ore Geol. Rev. 2019, 111, 102979. [CrossRef]

90. Zhang, D.; Zhao, K.D.; Wang, B.D.; Cheng, K.D.; Luo, X.L.; Zhang, W.; Li, Q.; Jiang, S.Y. Cretaceous granitic magmatism and mineralization in the Shanhu W-Sn ore deposit in the Nanling Range in South China. Ore Geol. Rev. 2020, 126, 103758. [CrossRef]

91. Li, X.H.; Li, W.X.; Wang, X.C.; Li, Q.L.; Liu, Y.; Tang, G.Q. Role of mantle-derived magma in genesis of early Yanshanian granites in the Nanling Range, South China: In situ zircon Hf-O isotopic constraints. Sci. China Ser. D-Earth Sci. 2009, 52, 1262-1278. [CrossRef]

92. Murphy, J.B.; Nance, R.D. The Pangea conundrum. Geology 2008, 36, 703-706. [CrossRef]

93. Correia, P.; Murphy, J.B. Iberian-Appalachian connection is the missing link between Gondwana and Laurasia that confirms a Wegenerian Pangaea configuration. Sci. Rep. 2020, 10, 2498. [CrossRef] [PubMed]

94. Neiva, A.M.R. Portuguese granites associated with Sn-W and Au mineralizations. Bull. Geol. Soc. Finl. 2002, 74, 79-101. [CrossRef]

95. Seifert, T.; Sandmann, D. Mineralogy and geochemistry of indium-bearing polymetallic vein-type deposits: Implications for host minerals from the Freiberg district, Eastern Erzgebirge, Germany. Ore Geol. Rev. 2006, 28, 1-31. [CrossRef]

96. Zhang, R.Q.; Lehmann, B.; Seltmann, R.; Sun, W.D.; Li, C.Y. Cassiterite U-Pb geochronology constrains magmatic-hydrothermal evolution in complex evolved granite systems: The classic Erzgebirge tin province (Saxony and Bohemia). Geology 2017, 45, 1095-1098. [CrossRef]

97. Matte, P. The Variscan collage and orogeny (480-290 Ma) and the tectonic definition of the Armorica microplate: A review. Terra Nova 2001, 13, 122-128. [CrossRef]

98. Dupuis, N.E.; Braid, J.A.; Murphy, J.B.; Shail, R.K.; Archibald, D.A.; Nance, R.D. ${ }^{40} \mathrm{Ar} /{ }^{39}$ Ar phlogopite geochronology of lamprophyre dykes in Cornwall, UK: New age constraints on Early Permian post-collisional magmatism in the Rhenohercynian Zone, SW England. J. Geol. Soc. 2015, 172, 566-575. [CrossRef]

99. Sanderson, D.J.; Roberts, S.; Gumiel, P.; Greenfield, C. Quantitative Analysis of Tin- and Tungsten-Bearing Sheeted Vein Systems. Econ. Geol. 2008, 103, 1043-1056. [CrossRef]

100. Moscati, R.J.; Neymark, L.A. U-Pb geochronology of tin deposits associated with the Cornubian Batholith of southwest England: Direct dating of cassiterite by in situ LA-ICPMS. Miner. Depos. 2020, 55, 1-20. [CrossRef]

101. Vallance, J.; Cathelineau, M.; Marignac, C.; Boiron, M.C.; Fourcade, S.; Martineau, F.; Fabre, C. Microfracturing and fluid mixing in granites: W-(Sn) ore deposition at Vaulry (NW French Massif Central). Tectonophysics 2001, 336, 43-61. [CrossRef] 
102. Harlaux, M.; Romer, R.L.; Mercadier, J.; Morlot, C.; Marignac, C.; Cuney, M. 40 Ma of hydrothermal W mineralization during the Variscan orogenic evolution of the French Massif Central revealed by U-Pb dating of wolframite. Miner. Depos. 2018, 53, 21-51. [CrossRef]

103. Mateus, A.; Lopes, C.; Martins, L.; Goncalves, M.A. Current and Foreseen Tungsten Production in Portugal, and the Need of Safeguarding the Access to Relevant Known Resources. Resources 2021, 10, 64. [CrossRef]

104. Launay, G.; Sizaret, S.; Guillou-Frottier, L.; Gloaguen, E.; Pinto, F. Deciphering fluid flow at the magmatic-hydrothermal transition: A case study from the world-class Panasqueira W-Sn- $(\mathrm{Cu})$ ore deposit (Portugal). Earth Planet Sc. Lett. 2018, 499, 1-12. [CrossRef]

105. Codeço, M.S.; Weis, P.; Trumbull, R.B.; Glodny, J.; Wiedenbeck, M.; Romer, R.L. Boron isotope muscovite-tourmaline geothermometry indicates fluid cooling during magmatic-hydrothermal W-Sn ore formation. Econ. Geol. 2019, 114, 153-163. [CrossRef]

106. Cathelineau, M.; Boiron, M.C.; Marignac, C.; Dour, M.; Dejean, M.; Carocci, E.; Truche, L.; Pinto, F. High pressure and temperatures during the early stages of tungsten deposition at Panasqueira revealed by fluid inclusions in topaz. Ore Geol. Rev. 2020, $126,103741$. [CrossRef]

107. Higgins, N.C. Wolframite deposition in a hydrothermal vein system; the Grey River tungsten prospect, Newfoundland, Canada. Econ. Geol. 1985, 80, 1297-1327. [CrossRef]

108. Li, J.K.; Liu, Y.C.; Zhao, Z.; Chou, I.M. Roles of carbonate $/ \mathrm{CO}_{2}$ in the formation of quartz-vein wolframite deposits: Insight from the crystallization experiments of huebnerite in alkali-carbonate aqueous solutions in a hydrothermal diamond-anvil cell. Ore Geol. Rev. 2018, 95, 40-48. [CrossRef]

109. Liu, X.C.; Xiao, C.H. Wolframite solubility and precipitation in hydrothermal fluids: Insight from thermodynamic modeling. Ore Geol. Rev. 2020, 117, 103289. [CrossRef]

110. Vacher, A. Short study of fluid inclusions in a topaz from Montbelleux (Ille-et-vilaine). Bull. De La Soc. Fr. Mineral. Et De Cristallogr. 1976, 99, 131-133.

111. Higgins, N.C. Fluid inclusion evidence for the transport of tungsten by carbonate complexes in hydrothermal solutions. Can. J. Earth Sci. 1980, 17, 823-830. [CrossRef]

112. Shimizu, M.; Kato, A. Roquesite-bearing tin ores from the Omodani, Akenobe, Fukoku, and Ikuno polymetallic vein-type deposits in the inner zone of Southwestern Japan. Can. Mineral. 1991, 29, 207-215.

113. Migisha, C.J.R.; Both, R.A. Mineralogy and genesis of the Trench tungsten-molybdenum deposit, Mount Mulgine, Western Australia. Miner. Depos. 1991, 26, 247-256. [CrossRef]

114. Morishita, Y. Fluid evolution and geobarometry on the Ohtani and Kaneuchi tungsten-quartz vein deposits, Japan: Oxygen and carbon isotopic evidence. Miner. Depos. 1991, 26, 40-50. [CrossRef]

115. Roedder, E. Fluid inclusion studies on the porphyry-type ore deposits at Bingham, Utah, Butte, Montana, and Climax, Colorado. Econ. Geol. 1971, 66, 98-118. [CrossRef]

116. Ball, T.K.; Fortey, N.J.; Shepherd, T.J. Mineralization at the Carrock Fell Tungsten mine, N. England-Paragenetic, fluid inclusion and geochemical study. Miner. Depos. 1985, 20, 57-65. [CrossRef]

117. Campbell, A.R.; Robinsoncook, S. Infrared fluid inclusion microthermometry on coexisting wolframite and quartz. Econ. Geol. 1987, 82, 1640-1645. [CrossRef]

118. Lüders, V. Contribution of infrared microscopy to fluid inclusion studies in some opaque minerals (wolframite, stibnite, bournonite); metallogenic implications. Econ. Geol. 1996, 91, 1462-1468. [CrossRef]

119. Lüders, V. Contribution of infrared microscopy to studies of fluid inclusions hosted in some opaque ore minerals: Possibilities, limitations, and perspectives. Miner. Depos. 2017, 52, 663-673. [CrossRef]

120. Ortelli, M.; Kouzmanov, K.; Wälle, M.; Ubrig, N.; Casanova, V. Fluid Inclusion Studies in Opaque Ore Minerals: I. Trace Element Content and Physical Properties of Ore Minerals Controlling Textural Features in Transmitted Near-Infrared Light Microscopy. Econ. Geol. 2018, 113, 1845-1860. [CrossRef]

121. Casanova, V.; Kouzmanov, K.; Audétat, A.; Wälle, M.; Ubrig, N.; Ortelli, M.; Fontboté, L. Fluid Inclusion Studies in Opaque Ore Minerals: II. A Comparative Study of Syngenetic Synthetic Fluid Inclusions Hosted in Quartz and Opaque Minerals. Econ. Geol. 2018, 113, 1861-1883. [CrossRef]

122. Pudack, C.; Halter, W.E.; Heinrich, C.A.; Pettke, T. Evolution of Magmatic Vapor to Gold-Rich Epithermal Liquid: The Porphyry to Epithermal Transition at Nevados de Famatina, Northwest Argentina. Econ. Geol. 2009, 104, 449-477. [CrossRef]

123. Stefanova, E.; Driesner, T.; Zajacz, Z.; Heinrich, C.A.; Petrov, P.; Vasilev, Z. Melt and Fluid Inclusions in Hydrothermal Veins: The Magmatic to Hydrothermal Evolution of the Elatsite Porphyry Cu-Au Deposit, Bulgaria. Econ. Geol. 2014, 109, 1359-1381. [CrossRef]

124. Ni, P.; Pan, J.Y.; Wang, G.G.; Chi, Z.; Qin, H.; Ding, J.Y.; Chen, H. A CO 2 -rich porphyry ore-forming fluid system constrained from a combined cathodoluminescence imaging and fluid inclusion studies of quartz veins from the Tongcun Mo deposit, South China. Ore Geol. Rev. 2017, 81, 856-870. [CrossRef]

125. Liu, Z.; Ni, P.; Zhang, Y.Q.; Sheng, Z.L.; Wang, G.G.; Zhang, S.L.; Dai, B.Z.; Ding, J.Y.; Pan, J.Y.; Li, W.S. An Early Cretaceous gold metallogenesis in the Wuhe area, eastern Anhui province: Constraints from geology, fluid inclusion, $\mathrm{H}-\mathrm{O}$ isotope and geochronology on the Hekou gold deposit. Ore Geol. Rev. 2021, 138, 104319. [CrossRef]

126. Huang, H.L.; Chang, H.L.; Tan, J.; Li, F.; Zhang, C.H.; Zhou, Y. Contrasting infrared microthermometry study of fluid inclusions in coexisting quartz, wolframite and other minerals: A case study of Xihuashan quartz-vein tungsten deposit, China. Acta Petrol. Sin. 2015, 31, 925-940. (In Chinese with English Abstract). 
127. Wu, B.; Wang, R.; Li, G.; Liao, Y. Mineralogy and fluid inclusion study of the Anqiantan tungsten deposit in southern Jiangxi Province. Journal of Nanjing University. Nat. Sci. 2020, 56, 788-799. (In Chinese with English Abstract).

128. Bailly, L.; Grancea, L.; Kouzmanov, K. Infrared microthermometry and chemistry of wolframite from the Baia Sprie epithermal deposit, Romania. Econ. Geol. 2002, 97, 415-423. [CrossRef]

129. Moura, A.; Dória, A.; Neiva, A.M.R.; Leal Gomes, C.; Creaser, R.A. Metallogenesis at the Carris W-Mo-Sn deposit (Gerês, Portugal): Constraints from fluid inclusions, mineral geochemistry, Re-Os and He-Ar isotopes. Ore Geol. Rev. 2014, 56, 73-93. [CrossRef]

130. Rios, F.J.; Villas, R.N.; Fuzikawa, K. Fluid evolution in the Pedra Preta wolframite ore deposit, paleoproterozoic Musa granite, eastern Amazon craton, Brazil. J. S. Am. Earth Sci. 2003, 15, 787-802. [CrossRef]

131. Candela, P.A. Controls on ore metal ratios in granite-related ore systems- an experimental and computational approach. Earth Environ. Sci. Trans. R. Soc. Edinb. 1992, 83, 317-326. [CrossRef]

132. Audétat, A.; Edmonds, M. Magmatic-hydrothermal fluids. Elements 2020, 16, 401-406. [CrossRef]

133. Wang, X.S.; Williams-Jones, A.E.; Hu, R.Z.; Shang, L.B.; Bi, X.W. The role of fluorine in granite-related hydrothermal tungsten ore genesis: Results of experiments and modeling. Geochim. Cosmochim. Acta 2021, 292, 170-187. [CrossRef]

134. Chang, H.L.; Wang, X.W.; Wang, X.D.; Liu, J.Q.; Huang, H.L. The composition of melt inclusions in beryl from wolframite-quartz veins in Xihuashan, Jiangxi Province. Acta Petrol. et Mineral. 2007, 26, 259-268. [CrossRef]

135. Alekseev, V.I.; Gembitskaya, I.M.; Marin, Y.B. Wolframoixiolite and niobian ferberite from zinnwaldite granitic rocks of the Chukchi Peninsula. Geol. Ore Depos. 2011, 53, 639-648. [CrossRef]

136. Catchpole, H.; Kouzmanov, K.; Fontbote, L.; Guillong, M.; Heinrich, C.A. Fluid evolution in zoned Cordilleran polymetallic veins-Insights from microthermometry and LA-ICP-MS of fluid inclusions. Chem. Geol. 2011, 281, 293-304. [CrossRef]

137. Wei, W.F.; Hu, R.Z.; Bi, X.W.; Peng, J.T.; Su, W.C.; Song, S.Q.; Shi, S.H. Infrared microthermometric and stable isotopic study of fluid inclusions in wolframite at the Xihuashan tungsten deposit, Jiangxi province, China. Miner. Depos. 2012, 47, 589-605. [CrossRef]

138. Myint, A.Z.; Yonezu, K.; Boyce, A.J.; Selby, D.; Schersten, A.; Tindell, T.; Watanabe, K.; Swe, Y.M. Stable isotope and geochronological study of the Mawchi Sn-W deposit, Myanmar: Implications for timing of mineralization and ore genesis. Ore Geol. Rev. 2018, 95, 663-679. [CrossRef]

139. Marin, Y.B. Accessory Minerals of Granitic Rocks in Tin and Molybdenum Provinces, Zap. Vseros. Miner. Ova. $2004,133,1-7$.

140. Syritso, L.F.; Badanina, E.V.; Volkova, E.V. Relationship of Quartz-Wolframite Veins with Granitic Magmatism. In Voprosy Geokhimii i Tipomorfizma Mineralov (Geochemistry and Typomorphism of Minerals); Gordienko, V.V., Ed.; St. Petersburg State Univ.: St. Petersburg, Russia, 2008; Volume 6, pp. 29-41.

141. Wang, Y.L.; Zhu, X.Y.; Li, S.T. Cheng, X.Y. Study on Mineralogical Characteristics of Yaogangxian granite wolframite in Hunan. Geol. Rev. 2015, 61, 548-549. (In Chinese with English Abstract).

142. Lai, J.Q.; Chi, G.X. $\mathrm{CO}_{2}$-rich fluid inclusions with chalcopyrite daughter mineral from the Fenghuangshan $\mathrm{Cu}-\mathrm{Fe}-\mathrm{Au}$ deposit, China: Implications for metal transport in vapor. Miner. Depos. 2007, 42, 293-299. [CrossRef]

143. Liu, Y.; Li, J.; Zhao, Z.; Liu, S.; Li, X. Discovery of $\mathrm{CO}_{2}$-bearing inclusions in greisen from the Taoxikeng tungsten deposit, southern Jiangxi Province and its metallogenic significance. Acta Geol. Sin. 2019, 93, 701-711. (In Chinese with English Abstract).

144. Wood, S.A.; Samson, I.M. The hydrothermal geochemistry of tungsten in granitoid environments: I. Relative solubilities of ferberite and scheelite as a function of T, P, pH, and $\mathrm{m} \mathrm{NaCl}$. Econ. Geol. 2000, 95, 143-182. [CrossRef]

145. Wang, X.S.; Timofeev, A.; Williams-Jones, A.E.; Shang, L.B.; Bi, X.W. An experimental study of the solubility and speciation of tungsten in NaCl-bearing aqueous solutions at 250, 300, and 350 degrees C. Geochim. Cosmochim. Acta 2019, 265, 313-329. [CrossRef]

146. Giuliani, G.; Li, Y.D.; Sheng, T.F. Fluid inclusion study of Xihuashan tungsten deposit in the Southern Jiangxi province, China. Miner. Depos. 1988, 23, 24-33. [CrossRef]

147. Xiong, Y.Q.; Shao, Y.J.; Zhou, H.D.; Wu, Q.H. Ore-forming mechanism of quartz-vein-type W-Sn deposits of the Xitian district in SE China: Implications from the trace element analysis of wolframite and investigation of fluid inclusions. Ore Geol. Rev. 2017, 83, 152-173. [CrossRef]

148. Legros, H.; Richard, A.; Tarantola, A.; Kouzmanov, K.; Mercadier, J.; Vennemann, T.; Marignac, C.; Cuney, M.; Wang, R.C.; Charles, N. Multiple fluids involved in granite-related W-Sn deposits from the world-class Jiangxi province (China). Chem. Geol. 2019, 508, 92-115. [CrossRef]

149. Jaireth, S.; Heinrich, C.A.; Solomon, M. Chemical controls on the hydrothermal tungsten transport in some magmatic systems and the precipitation of ferberite and scheelite. Geol. Soc. Aust. Abs. 1990, 25, 269-270.

150. Heinrich, C.A. The chemistry of hydrothermal tin (-tungsten) ore deposition. Econ. Geol. 1990, 85, 457-481. [CrossRef]

151. Krylova, T.L.; Pandian, M.S.; Bortnikov, N.S.; Gorelikova, N.V.; Gonevchuk, V.G.; Korostelev, P.G. Degana (Rajasthan, India) and Tigrinoe (Primorye, Russia) tungsten and tin-tungsten deposits: Composition of mineral-forming fluids and conditions of wolframite deposition. Geol. Ore Depos. 2012, 54, 276-294. [CrossRef]

152. Beuchat, S.; Moritz, R.; Pettke, T. Fluid evolution in the $\mathrm{W}-\mathrm{Cu}-\mathrm{Zn}-\mathrm{Pb}$ San Cristobal vein, Peru: Fluid inclusion and stable isotope evidence. Chem. Geol. 2004, 210, 201-224. [CrossRef]

153. Cerny, P.; Blevin, P.L.; Cuney, M.; London, D. Granite-related ore deposits. Economic Geology 100th Anniversary Volume. Econ. Geol. 2005, 337-370. 
154. Kozlik, M.; Raith, J.G.; Gerdes, A. U-Pb, Lu-Hf and trace element characteristics of zircon from the Felbertal scheelite deposit (Austria): New constraints on timing and source of W mineralization. Chem. Geol. 2016, 421, 112-126. [CrossRef]

155. Reyf, F.G. Direct evolution of W-rich brines from crystallizing melt within the Mariktikan granite pluton, west Transbaikalia. Miner. Depos. 1997, 32, 475-490. [CrossRef]

156. Van Daele, J.; Hulsbosch, N.; Dewaele, S.; Boiron, M.C.; Piessens, K.; Boyce, A.; Muchez, P. Mixing of magmatic-hydrothermal and metamorphic fluids and the origin of peribatholitic Sn vein-type deposits in Rwanda. Ore Geol. Rev. 2018, 101, 481-501. [CrossRef]

157. Xu, K.Q.; Hu, S.X.; Sun, M.Z.; Ye, J. Geological Characteristics and Prospecting Potential of Two granites in South China. Miner. Depos. 1982, 2, 1-14. (In Chinese with English Abstract).

158. Raith, J.G.; Prochaska, W. Tungsten deposits in the Wolfram schist, Namaqualand, South Africa: Strata-bound versus graniterelated genetic concepts. Econ. Geol. 1995, 90, 1934-1954. [CrossRef]

159. Chiaradia, M. The evolution of tungsten sources in crustal mineralization from archean to tertiary inferred from lead isotopes. Econ. Geol. 2003, 98, 1039-1045. [CrossRef]

160. Hua, R.M.; Chen, P.R.; Zhang, W.L.; Yao, J.M.; Lin, J.F.; Zhang, Z.S. Metallogeneses and their geodynamic settings related to Mesozoic granitoids in the Nanling range. Geol. J. China Univ. 2005, 11, 291-304. (In Chinese with English Abstract).

161. Romer, R.L.; Kroner, U. Sediment and weathering control on the distribution of Paleozoic magmatic tin-tungsten mineralization. Miner. Depos. 2015, 50, 327-338. [CrossRef]

162. Matthews, A.; Fouillac, C.; Hill, R.; O'Nions, R.K.; Oxburgh, E.R. Mantle-derived volatiles in continental crust: The Massif Central of France. Earth Planet Sc. Lett. 1987, 85, 117-128. [CrossRef]

163. Simmons, S.F.; Sawkins, F.J.; Schlutter, D.J. Mantle-derived helium in two Peruvian hydrothermal ore deposits. Nature 1987, 329, 429-432. [CrossRef]

164. Stuart, F.M.; Turner, G.; Duckworth, R.C.; Fallick, A.E. Helium isotopes as tracers of trapped hydrothermal fluids in ocean-floor sulfides. Geology 1994, 22, 823-826. [CrossRef]

165. Turner, G.; Burgess, R.; Bannon, M. Volatile-rich mantle fluids inferred from inclusions in diamond and mantle xenoliths. Nature 1990, 344, 653-655. [CrossRef]

166. Zhai, W.; Sun, X.M.; Wu, Y.S.; Sun, Y.Y.; Hua, R.M.; Ye, X.R. He-Ar isotope geochemistry of the Yaoling-Meiziwo tungsten deposit, North Guangdong Province: Constraints on Yanshanian crust-mantle interaction and metallogenesis in SE China. Chin. Sci. Bull. 2012, 57, 1137-1146. (In Chinese with English Abstract). [CrossRef]

167. Wang, R.C.; Zhu, J.C.; Zhang, W.L.; Xie, L.; Yu, A.P.; Che, X.D. Ore-forming mineralogy of W-Sn granites in the Nanling range: Concept and case study. Geol. J. China Uni. 2008, 14, 485-495. (In Chinese with English Abstract).

168. Li, G.L. Yanshanian Granite Evolution and Tungsten Mineralization in Southern Jiangxi and Its Adjacent Areas. Ph.D. Dissertation, Nanjing University, Nanjing, China, 2011; p. 192. (In Chinese with English Abstract).

169. Xu, J.X.; Zeng, Z.L.; Wang, D.H.; Chen, Z.H.; Liu, S.B.; Wang, C.H.; Ying, L.J. A new type of tungsten deposit in southern Jiangxi and the new model of "Five floors + Basement" for prospecting. Acta Geol. Sin. 2008, 82, 880-887. (In Chinese with English Abstract).

170. Sun, Y.C.; Chen, Z.H.; Zhao, G.C.; Huang, H.X.; Zeng, L.; Yan, C.; Wu, S.C. 40Ar/ 39Ar dating of muscovite from the contact zone of granite-aplites in the Dengfuxian W-Nb-Ta deposit and its geological significance. Geol. Bull. China 2017, 36, 466-476. (In Chinese with English Abstract).

171. He, M.; Hou, Q.L.; Liu, Q.; Zhang, J.H.; Sun, J.F.; Wu, S.C.; Zhu, H.F. Timing and structural controls on skarn-type and vein-type mineralization at the Xitian tin-polymetallic deposit, Hunan Province, SE China. Acta Geochim. 2018, 37, 295-309. [CrossRef]

172. Yang, M.G.; Zeng, Z.L.; Lai, Z.J.; Wu, X.H. The "multi-position in one" mode and dynamic mechanism of mineralization of tungsten deposits in Jiangxi. J. Geomech. 2008, 14, 241-250. (In Chinese with English Abstract).

173. Feng, C.Y.; Feng, Y.D.; Xu, J.X.; Zeng, Z.L.; She, H.Q.; Zhang, D.Q.; Qu, W.J.; Du, A.D. Isotope chrpnological evidence for Upper Jurassic petrogenesis and mineralization of altered granite-type tungsten deposits in the Zhangtiantang area, southern Jiangxi. Geol. China. 2007, 34, 642-650. (In Chinese with English Abstract).

174. Deng, X.D.; Luo, T.; Li, J.W.; Hu, Z.C. Direct dating of hydrothermal tungsten mineralization using in situ wolframite U-Pb chronology by laser ablation ICP-MS. Chem. Geol. 2019, 515, 94-104. [CrossRef]

175. Yang, J.H.; Peng, J.T.; Zhao, J.H.; Fu, Y.Z.; Yang, C.; Hong, Y.L. Petrogenesis of the Xihuashan Granite in Southern Jiangxi Province, South China: Constraints from Zircon U-Pb Geochronology, Geochemistry and Nd Isotopes. Acta Geol. Sin.-Engl. Ed. 2012, 86, 131-152. [CrossRef]

176. Heinrich, C.A.; Pettke, T.; Halter, W.E.; Aiger-Torres, M.; Audétat, A.; Günther, D.; Hattendorf, B.; Bleiner, D.; Guillong, M.; Horn, I. Quantitative multi-element analysis of minerals, fluid and melt inclusions by laser-ablation inductively-coupled-plasma mass-spectrometry. Geochim. Cosmochim. Acta 2003, 67, 3473-3496. [CrossRef]

177. Shepherd, T.J.; Chenery, S.R. Laser ablation ICP-MS elemental analysis of individual fluid inclusions: An evaluation study. Geochim. Cosmochim. Acta 1995, 59, 3997-4007. [CrossRef]

178. Su, W.C.; Heinrich, C.A.; Pettke, T.; Zhang, X.C.; Hu, R.Z.; Xia, B. Sediment-hosted gold deposits in Guizhou, China: Products of wall-rock sulfidation by deep crustal fluids. Econ. Geol. 2009, 104, 73-93. [CrossRef] 
179. Pettke, T.; Oberli, F.; Audétat, A.; Guillong, M.; Simon, A.C.; Hanley, J.J.; Klemm, L.M. Recent developments in element concentration and isotope ratio analysis of individual fluid inclusions by laser ablation single and multiple collector ICP-MS. Ore Geol. Rev. 2012, 44, 10-38. [CrossRef]

180. Audétat, A. The metal content of magmatic-hydrothermal fluids and its relationship to mineralization potential. Econ. Geol. 2019, 114, 1033-1056. [CrossRef]

181. Audétat, A.; Pettke, T.; Heinrich, C.A.; Bodnar, R.J. The Composition of Magmatic-Hydrothermal Fluids in Barren and Mineralized Intrusions. Econ. Geol. 2008, 103, 877-908. [CrossRef]

182. Zajacz, Z.; Halter, W.E.; Pettke, T.; Guillong, M. Determination of fluid/melt partition coefficients by LA-ICPMS analysis of co-existing fluid and silicate melt inclusions: Controls on element partitioning. Geochim. Cosmochim. Acta 2008, 72, $2169-2197$. [CrossRef]

183. Lehmann, B.; Ishihara, S.; Michel, H.; Miller, J.; Rapela, C.W.; Sanchez, A.; Tistl, M.; Winkelmann, L. The Bolivian tin province and regional tin distribution in the Central Andes; a reassessment. Econ. Geol. 1990, 85, 1044-1058. [CrossRef]

184. Blevin, P.L.; Chappell, B.W.; Allen, C.M. Intrusive metallogenic provinces in eastern Australia based on granite source and composition. Earth Environ. Sci. Trans. R. Soc. Edinb. 1996, 87, 281-290. [CrossRef]

185. Webster, J.D.; Thomas, R.; Rhede, D.; Forster, H.J.; Seltmann, R. Melt inclusions in quartz from an evolved peraluminous pegmatite: Geochemical evidence for strong tin enrichment in fluorine-rich and phosphorus-rich residual liquids. Geochim. Cosmochim. Acta 1997, 61, 2589-2604. [CrossRef]

186. Chen, J.; Wang, R.C.; Zhu, J.C.; Lu, J.J.; Ma, D.S. Multiple-aged granitoids and related tungsten-tin mineralization in the Nanling Range, South China. Sci. China-Earth Sci. 2013, 56, 2045-2055. [CrossRef]

187. Wu, M.Q.; Samson, I.M.; Zhang, D.H. Textural and Chemical Constraints on the Formation of Disseminated Granite-hosted W-Ta-Nb Mineralization at the Dajishan Deposit, Nanling Range, Southeastern China. Econ. Geol. 2017, 112, 855-887. [CrossRef]

188. Huang, X.D.; Lu, J.J.; Sizaret, S.; Wang, R.C.; Ma, D.S.; Zhang, R.Q.; Zhao, X.; Wu, J.W. Petrogenetic differences between the Middle-Late Jurassic $\mathrm{Cu}-\mathrm{Pb}-\mathrm{Zn}$-bearing and $\mathrm{W}$-bearing granites in the Nanling Range, South China: A case study of the Tongshanling and Weijia deposits in southern Hunan Province. Sci. China Earth Sci. 2017, 60, 1220-1236. (In Chinese with English Abstract). [CrossRef]

189. Wei, Q. The geochemistry and morphology of titanite as indicators for W, Fe, Au mineralization. China Univ. Geosci. 2020. (In Chinese with English Abstract).

190. Gardiner, N.J.; Hawkesworth, C.J.; Robb, L.J.; Whitehouse, M.J.; Roberts, N.; Kirkland, C.L.; Evans, N.J. Contrasting Granite Metallogeny through the Zircon Record: A Case Study from Myanmar. Sci. Rep. 2017, 7, 748. [CrossRef]

191. Yuan, S.D.; Williams-Jones, A.E.; Romer, R.L.; Zhao, P.L.; Mao, J.W. Protolith-related thermal controls on the decoupling of Sn and W in Sn-W metallogenic provinces: Insights form the Nanling region, China. Econ. Geol. 2019, 114, 1005-1012. [CrossRef]

192. Lerchbaumer, L.; Audétat, A. The Metal Content of Silicate Melts and Aqueous Fluids in Subeconomically Mo Mineralized Granites: Implications for Porphyry Mo Genesis. Econ. Geol. 2013, 108, 987-1013. [CrossRef]

193. Audétat, A. Compositional Evolution and Formation Conditions of Magmas and Fluids Related to Porphyry Mo Mineralization at Climax, Colorado. J. Petrol. 2015, 56, 1519-1546. [CrossRef]

194. Zhang, D.H.; Audétat, A. Chemistry, Mineralogy and Crystallization Conditions of Porphyry Mo-forming Magmas at UradHenderson and Silver Creek, Colorado, USA. J. Petrol. 2017, 58, 277-296. [CrossRef]

195. Zhang, D.H.; Audétat, A. What Caused the Formation of the Giant Bingham Canyon Porphyry Cu-Mo-Au Deposit? Insights from Melt Inclusions and Magmatic Sulfides. Econ. Geol. 2017, 112, 221-244. [CrossRef]

196. Audétat, A.; Pettke, T. The magmatic-hydrothermal evolution of two barren granites: A melt and fluid inclusion study of the Rito del Medio and Canada Pinabete plutons in northern New Mexico (USA). Geochim. Cosmochim. Acta 2003, 67, 97-121. [CrossRef] 